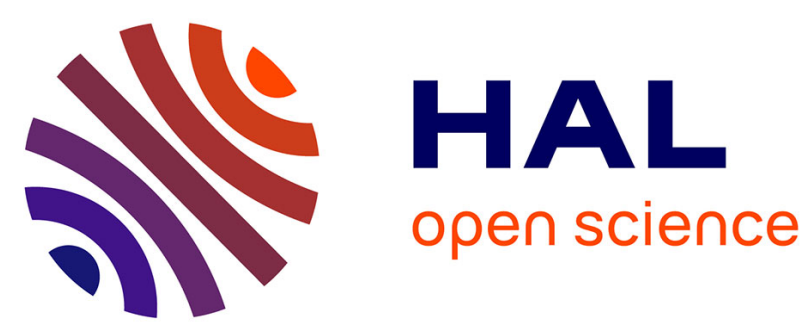

\title{
Reconstruction of a saline, lacustrine carbonate system (Priabonian, St-Chaptes Basin, SE France): depositional models, paleogeographic and paleoclimatic implications.
}

Alexandre Lettéron, Youri Hamon, François Fournier, Michel Séranne, Pierre Pellenard, Philippe Joseph

\section{To cite this version:}

Alexandre Lettéron, Youri Hamon, François Fournier, Michel Séranne, Pierre Pellenard, et al.. Reconstruction of a saline, lacustrine carbonate system (Priabonian, St-Chaptes Basin, SE France): depositional models, paleogeographic and paleoclimatic implications.. Sedimentary Geology, 2018, 367, pp.20-47. 10.1016/j.sedgeo.2017.12.023 . hal-01735281

\author{
HAL Id: hal-01735281 \\ https://hal.science/hal-01735281
}

Submitted on 18 Nov 2020

HAL is a multi-disciplinary open access archive for the deposit and dissemination of scientific research documents, whether they are published or not. The documents may come from teaching and research institutions in France or abroad, or from public or private research centers.
L'archive ouverte pluridisciplinaire HAL, est destinée au dépôt et à la diffusion de documents scientifiques de niveau recherche, publiés ou non, émanant des établissements d'enseignement et de recherche français ou étrangers, des laboratoires publics ou privés. 


\title{
Reconstruction of a saline, lacustrine carbonate system (Priabonian, St-Chaptes Basin, SE France): depositional models, paleogeographic and paleoclimatic implications.
}

\author{
Alexandre Lettéron a,b*, Youri Hamon", François Fournier ${ }^{b}$, Michel \\ Séranne ${ }^{c}$, Pierre Pellenard ${ }^{d}$, Philippe Josepha.
}

a - IFP Energies nouvelles (IFPEN), 1-4, avenue de Bois-Préau, 92852 Rueil-Malmaison, France.

b- Aix-Marseille Université, CNRS, IRD, CEREGE, UMR 7330, 3 Place Victor Hugo (Case 67), 13331 Marseille Cedex 03, France.

c-Geosciences Montpellier, Université de Montpellier, 34095 Montpellier Cedex 05, France.

d-Biogéosciences, UMR 6282, CNRS, Université Bourgogne Franche-Comté, 6 Bd Gabriel, 21000 Dijon, France.

*Alexandre Lettéron, alexandre.letteron@gmail.com

\section{ABSTRACT:}

A 220-meters thick carbonate-dominated succession has been deposited in shallow-water, saline lake environments during the Lower to Middle Priabonian (MP17A-MP18 mammal zones) in the Saint-Chaptes Basin (south-east France). The palaeoenvironmental, paleoclimatic and palaeogeographic significance of such salt lake carbonates has been deciphered on the basis of a multi-proxy analyses including 1) depositional and diagenetic features, 2) biological components (molluscs, benthic foraminifera, characean gyrogonites, spores and pollens), 3) carbon and oxygen stable isotopes, 4) trace elements and 5) clay mineralogy. Five stages of lacustrine system evolution have been identified: 1) fresh-water closed lake under dry climate (unit U1); 2) fresh to brackish water lacustrine deltaic system with a mixed carbonate-siliciclastic sedimentation under relatively wet climatic conditions (unit U2); 3) salt-water lacustrine carbonate system under humid climatic setting (unit U3); 4) evaporitic lake (unit U4); and 5) closed lake with shallow-water carbonate sedimentation under subtropical to Mediterranean climate with dry seasons (unit U5). Upper Eocene aridification is evidenced to have started as early as the earliest Priabonian (unit U1: MP17A mammal zone). A change from humid to dryer climatic conditions is recorded between units U3 and U4. The Lower-Mid Priabonian saline lake is interpreted as an athalassic (inland) lake that have been transiently connected with neighboring salt lakes influenced by seawater and/or fed with sulfates deriving from recycling of evaporites. Maximum of connection with neighboring salt-lakes (Mormoiron Basin, Camargue and Central grabens, Hérault Basin) likely occurred during unit U3 and at the base of unit U5. The most likely sources of salts of these adjacent basins are: 1) Triassic evaporites derived from salt-diapirs (Rhône valley) or from paleo-outcrops located east of the Durance fault or offshore in the Gulf of Lion; or 2) marine incursions from the south, through Paleogene grabens in the Gulf of Lion.

Keywords: Upper Eocene, Salt lakes, Lacustrine carbonates, Depositional facies, Paleoenvironments, Paleoclimate, Paleogeography. 


\section{Introduction}

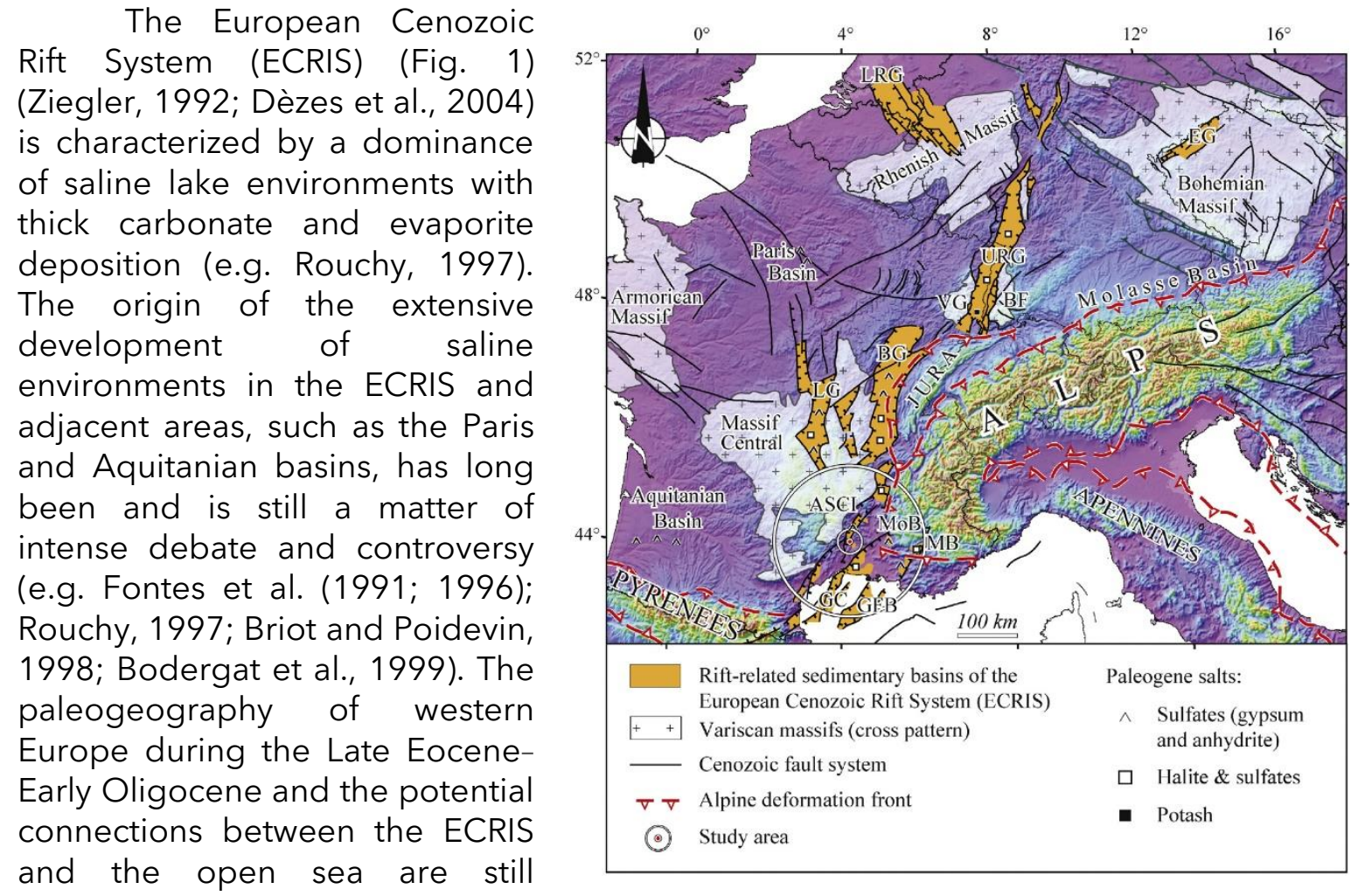

unresolved problems (Rouchy and Blanc-Valleron, 2009). Biological components of marine affinities are common in the Priabonian and Rupelian sedimentary record in the ECRIS, but their high tolerance to large variations of salinities prevents their use as reliable indicators of marine connections (Briot, 2008).

\begin{abstract}
Fig. 1. Location map of the study area in the European Cenozoic Rift System (ECRIS). Paleogene evaporites distribution modified from Rouchy and Blanc-Valleron, 2009; structural map modified after Dèzes et al., 2004; Ziegler and Dèzes, 2005. DEM from ASTER Global Digital Elevation Map is a product of METI and NASA. Abbreviations: ASCl: Alès-Saint-Chaptes-Issirac Basin, BF: Black Forest, BG: Bresse Graben, EG: Eger Graben, GC: Graben Central, GFB: Grand Faraman Basin, LG: Limagne Graben, LRG: Lower Rhine Graben, MB: Manosque Basin, MoB: Mormoiron Basin, URG: Upper Rhine Graben, VG: Vosges massif.
\end{abstract}

The Late Eocene is a key period for Cenozoic climate changes prior to the Terminal Eocene Event (TEE), which is considered as a period of intense climatic deterioration (e.g. Soták, 2010). A global cooling event is evidenced by various paleoclimatic proxies: 1) $\Delta_{47}$ clumped isotopes (Hren et al., 2013); 2) oxygen-isotope ratio $\left(\delta^{18} \mathrm{O}\right)$ of deep-sea benthic foraminifera (e.g. Shackleton, 1986; Miller et al., 2009); 3) paleobotanical data (e.g. Châteauneuf, 1980; Collinson et al., 1981; Schuler, 1990; Mosbrugger et al., 2005; Uhl et al., 2007); 4) lipid-based $\mathrm{UK}^{\mathrm{K}_{37}}$ and $\mathrm{TEX}_{86}$ (e.g. Liu et al., 2009); 5) otolith oxygen isotope (Ivany et al., 2000); 6) clay mineralogy (e.g. Singer, 1984; Ehrmann and Mackensen, 1992); and 7) Mg/Ca paleothermometry (e.g. Katz et al., 2008).

The Late Eocene is a prolific period of lacustrine and palustrine carbonate sedimentation in south of France, particularly in Languedoc basins (Hérault Basin, AlèsSaint-Chaptes-Issirac Basin (ASCI) (Fig. 1) (e.g. Lettéron et al., 2017) and in the Rhodanian Valley area (Manosque Basin, Mormoiron Basin) (Fig. 1) (e.g. Triat and Truc, 1974). However, carbonate depositional models of carbonate saline lakes from ECRIS and related 

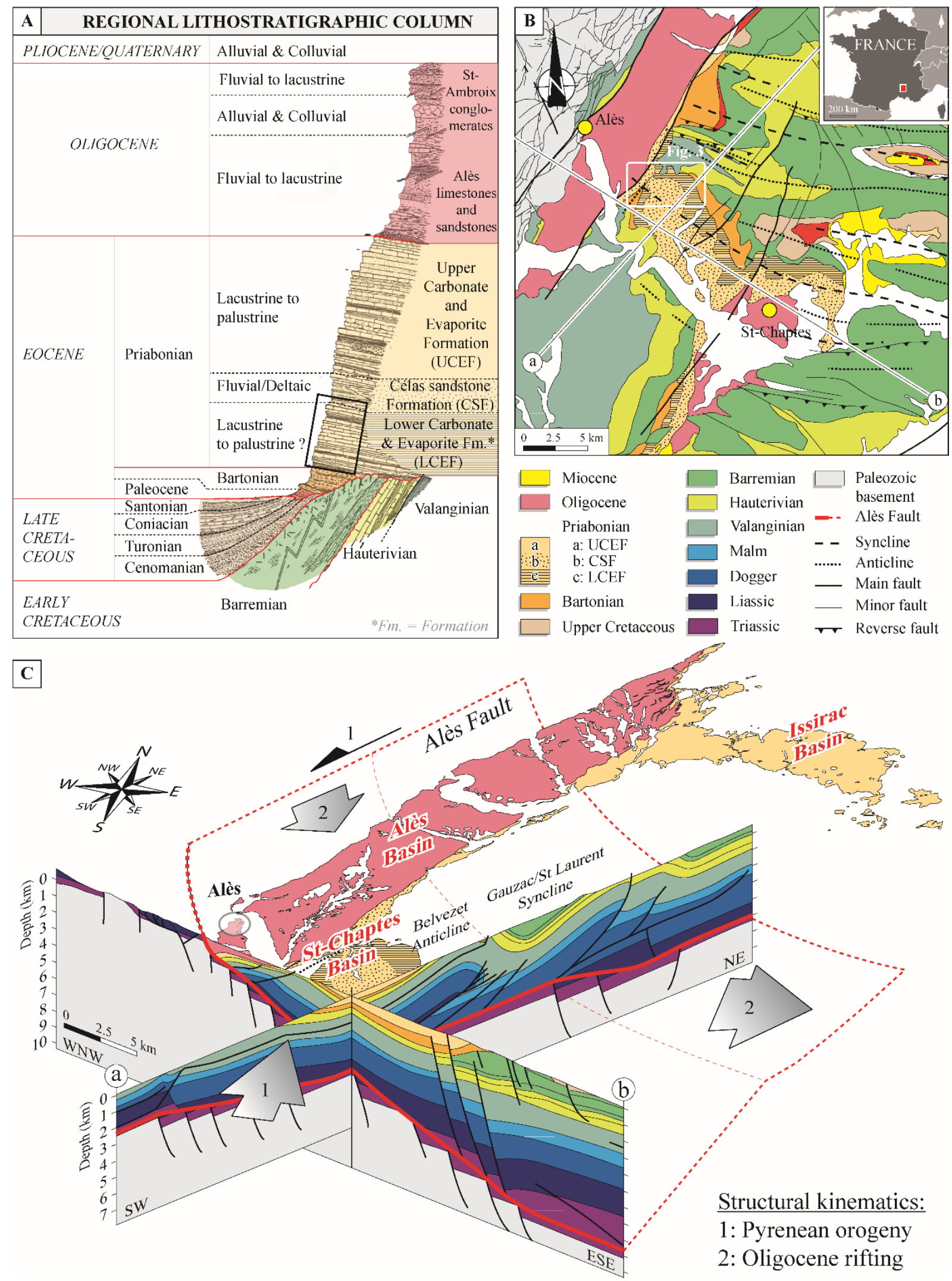

Fig. 2. Geological setting of the Saint-Chaptes Basin (SE France) and adjacent Paleogene basins: (A) Regional lithostratigraphy of the Alès-Saint-Chaptes-Issirac (ASCI) basins, modified after Alabouvette et al., 1983. (B) Simplified geological map of the Saint-Chaptes Basin. (C) 3D view of geological cross-sections across the Saint-Chaptes Basin; cross-sections derived from the interpretation of 2D seismic profiles (Sanchis and Séranne, 2000): location is reported on Fig. $2 B$.

Lettéron, A., Hamon, Y., Founier, F., Séranne, M., Pellenard, P. and Jospeh, P., 2018. Reconstrcutnion of a saline, lacustrine carbonate system (Priabonian, St-Chaptes Basin, SE France): depositional models, paleogeogrpahix and paleoclimatic implications. Sedimentary Geology, 367, 20-47. 
driving factors are rare (e.g. Triat and Truc, 1974). A detailed and integrated paleoecological, paleoenvironmental, sedimentological and geochemical characterization of such saline, lacustrine carbonate systems should provide relevant insights into paleogeographic and paleoclimatic reconstructions for south-east France Priabonian basins (Lettéron et al., 2017). The Lower to Middle Priabonian lacustrine-to-palustrine sedimentary succession is particularly well exposed in the Saint-Chaptes Basin (see location in Figs 2 and 3) (Alabouvette et al., 1983; Frédet, 1987). Based on an extensive sedimentological, paleontological (molluscs, benthic foraminifera, characean, spores and pollens), mineralogical (clay assemblage analyses) and geochemical (trace elements, carbon and oxygen stable isotopes) database, the present contribution brings new insights into the interpretation of depositional models of such saline lakes and the deciphering of paleoclimatic and paleogeographic signals from the sedimentary record.

The present work aims at: 1) constraining the paleoenvironmental interpretations of carbonate deposits in terms of salinity, water-depth, hydrodynamics and temperature; 2) providing depositional models for the Priabonian shallow-water, saline lake of the SaintChaptes Basin; 3) linking the vertical and lateral evolution of depositional environments and geochemical signatures (trace elements, carbon and oxygen isotope ratios) with changes in salinity, relative lake level, climate and potential connectivity with adjacent marine or lacustrine realms; and finally 4) providing regional paleogeographical interpretations for the development of saline lacustrine systems in Priabonian rift basins from the south-east of France.

\section{Geological setting}

The Saint-Chaptes Basin (SE France - Fig. 2B) is a small $(25 \times 10 \mathrm{~km}), \mathrm{N} 130^{\circ}$ elongated syncline basin (Figs $2 \mathrm{~B}$ and $2 \mathrm{C}$ ). Its apparent asymmetry is related to its multiphase structural history (Mascle and Vially, 1999). During the Late Cretaceous to Eocene Pyrenean compressive phase (Arthaud and Seguret, 1981), the northward displacement and folding of the Mesozoic to Eocene sedimentary cover occurred above a regional asymmetric detachment/decollement level within the Triassic evaporitic succession (Fig. 2C) (Séranne et al., 1995) resulting in various east-west trending folded structures (e.g. St-Chaptes Basin, Gauzac-St-Laurent syncline, Issirac Basin; Arthaud and Séguret, 1981; Benedicto Esteban, 1996; Sanchis and Séranne, 2000).

The Priabonian sedimentary succession from the Saint-Chaptes Basin is partly coeval with the development of the Alès half-graben along the Cévennes fault system during the Late Eocene to Early Oligocene West European rifting phase (e.g. Mauffret and Gorini, 1996; Michon, 2000; Sanchis and Séranne, 2000). In the Saint-Chaptes Basin, the Priabonian succession unconformably deposited (onlap or erosional surfaces) onto Pyrenean-related structures (Late Cretaceous-Late Eocene). These are later unconformably overlain by Upper Oligocene continental terrigenous series (Fig. 2) temporally consistent with the formation of the Alès extensional ramp-flat system (Sanchis and Séranne, 2000) related to the Liguro-Provençal rifting phase. The Priabonian succession of the Alès-StChaptes-Issirac (ASCl) Basin is summarized in Figure 2A. Both in the St-Chaptes and the Alès basins, sporadic siliciclastic inputs occur into the carbonate-dominated interval (Frédet, 1987) (Figs 2A and 2B). Evidences of saline environments consist in gypsum and anhydrite deposition, dominance of brackish-water molluscs and ostracod assemblages (Roman, 1904) and the common occurrence of benthic foraminifera (Frédet, 1987). Available paleogeographic reconstructions of Late Eocene times and geochemical data

Lettéron, A., Hamon, Y., Founier, F., Séranne, M., Pellenard, P. and Jospeh, P., 2018. Reconstrcutnion of a saline, lacustrine carbonate system (Priabonian, St-Chaptes Basin, SE France): depositional models, paleogeogrpahix and paleoclimatic implications. Sedimentary Geology, 367, 20-47. 
(Sissingh, 2001; 2006; Andeweg, 2002; Lettéron et al., 2017) suggest episodic connections of the ASCl lake water with seawater-derived water bodies.

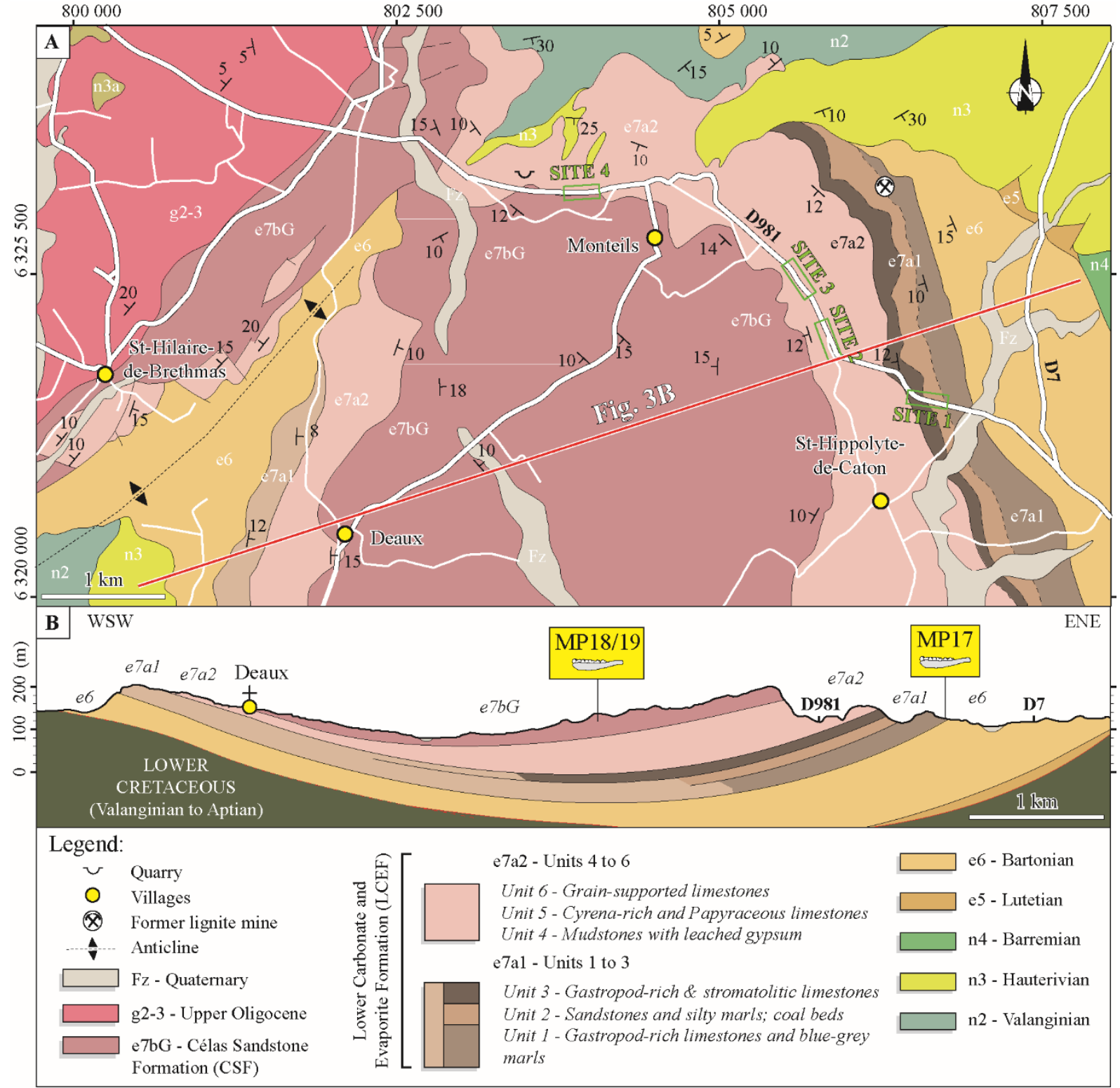

Fig. 3. (A) Geological map of the study area (see location in Fig. 1B) and location of the outcrops along the D981 road. BRGM 1/50 000 maps (Alès, Anduze). (B) Geological cross-section through the Saint-Chaptes syncline basin (see location on Fig. 3A). The mammalian biostratigraphic control points are reported (Depéret, 1917; Remy 1985, 1994).

\section{Methods and dataset}

The studied outcrops are located in the north-western part of the St-Chaptes Basin, along the D981 road, between Monteils and St-Hippolyte-de-Caton villages (Fig. 3). Four sections were logged and compiled in Figure 4. Analytical methods are outlined below. 


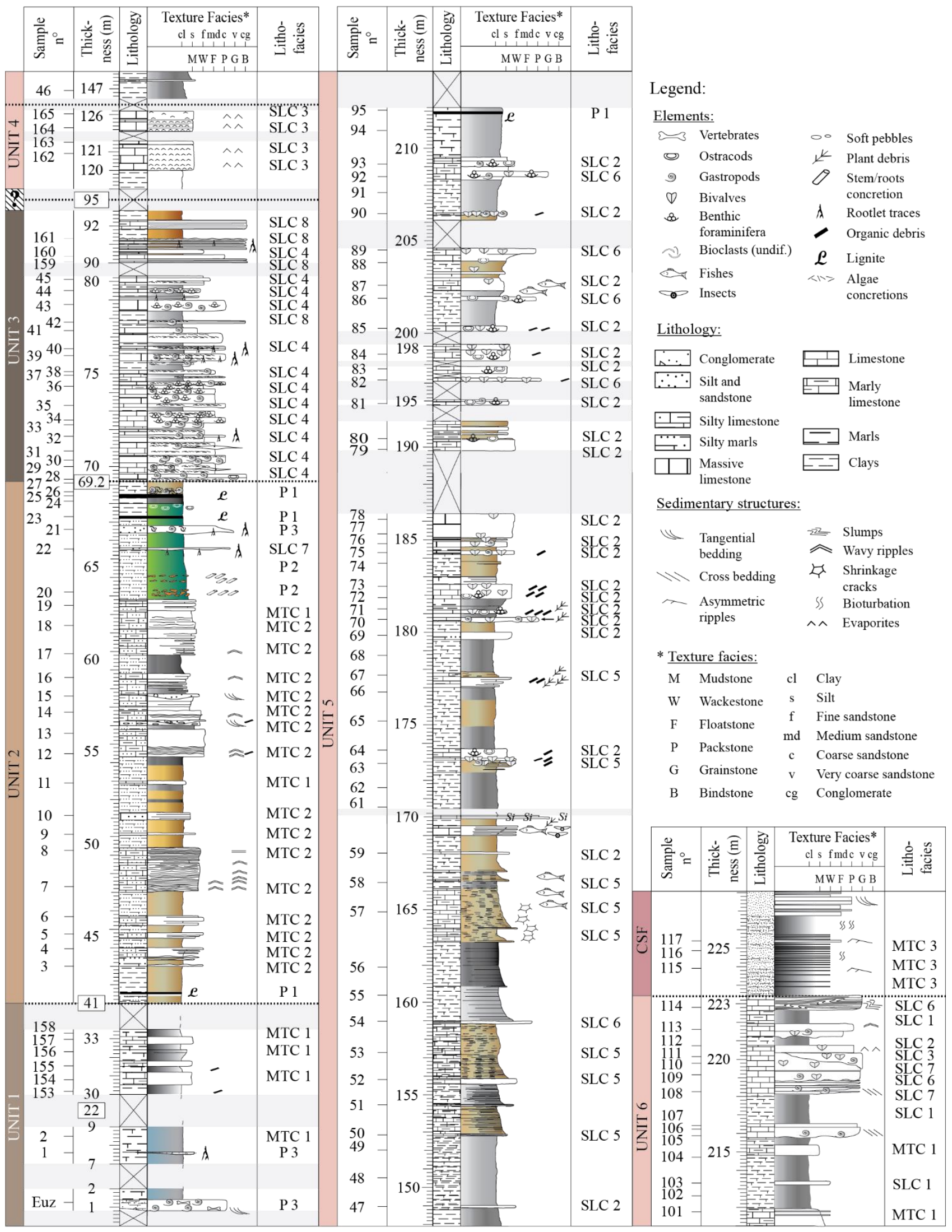

Fig. 4. Detailed composite sedimentary log section of the Priabonian Lower Carbonate and Evaporite Formation (LCEF) in the Saint-Chaptes Basin. Units U1, U2 and U3 have been logged in SITE 1 outcrop, U4 and base U5 in SITE 2, U5 in SITE 3, U6 and base CSF in SITE 4 (see locations of outcrops on Fig. 3). 


\subsection{Sedimentary petrography and analyses of biological components}

Petrographic analyses were conducted both macroscopically and microscopically on thin sections. Microscopic analyses have been performed with a Nikon Eclipse LV100 POL microscope, using conventional transmitted polarized light. Biological components have been synthesized from published data and used for chronostratigraphic purposes or paleoenvironmental and paleoclimatic reconstructions; these are spores and pollens (Gruas-Cavagnetto, 1973; Ellenberger, 1980; Alabouvette et al., 1983), molluscs (Depéret, 1917; Alabouvette et al., 1983), charophytes (Feist-Castel, 1971) and mammals (Depéret, 1917; Rémy, 1985; Rémy, 1994; Rémy and Lesage, 2003). Additional observations from the present database regarding molluscs, ostracods and benthic foraminifera have been also integrated.

\subsection{Major, minor and trace elements}

Whole-rock elemental determinations of major ( $\mathrm{Al}, \mathrm{Ca}, \mathrm{Mg}, \mathrm{Na}, \mathrm{K}, \mathrm{Ti}, \mathrm{Fe}, \mathrm{Mn}, \mathrm{P}, \mathrm{S}$ in percent) and minor elements (Mo, $\mathrm{Cu}, \mathrm{Pb}, \mathrm{Zn}, \mathrm{Ni}, \mathrm{Co}, \mathrm{As}, \mathrm{U}, \mathrm{Th}, \mathrm{Sr}, \mathrm{Cd}, \mathrm{Sb}, \mathrm{V}, \mathrm{La}, \mathrm{Cr}, \mathrm{Ba}, \mathrm{Sc}$, $\mathrm{Tl}, \mathrm{Se}, \mathrm{Ga}, \mathrm{Ge}, \mathrm{Rb}, \mathrm{Sn}, \mathrm{Zr}, \mathrm{Y}, \mathrm{Ce}$, Li in p.p.m. and $\mathrm{Au}, \mathrm{Ag}, \mathrm{Hg}$ in ppb) were carried out at Bureau Veritas Commodities Canada Ltd., Vancouver, Canada. A total of thirty-six rock samples (excluding blanks) were analyzed. The analyses were done by the inductively coupled plasma mass spectrometry using a PerkinElmer ICP-MS ELAN ${ }^{\star} 9000$ (PerkinElemer, Inc., Waltham, Massachusetts, USA) which was calibrated using Bureau Veritas interlaboratory standards DS10 and Oreas 45Ea. Samples were pulverized to a fine powder ( 3.75 phi). Subsamples weighing $\sim 1$ gram were digested by using the AQ250 Ultra Trace Geochemical aqua regia $\left(\mathrm{HNO}_{3}-\mathrm{HCl}\right)$ package for two hours at $95^{\circ} \mathrm{C}$. This digestion is only partial for $\mathrm{Cr}$ and Ba-bearing minerals and some oxides of $\mathrm{Al}, \mathrm{Hf}, \mathrm{Mn}, \mathrm{Sn}$, $\mathrm{Ta}$ and Zr. Volatilization may occur during fuming resulting in some loss of As and Sb. After cooling and dilution with deionized water, samples were analyzed using laser ablation and ICP-MS to determine the concentration of thirty-seven elements. Further details on the detection limits for the geochemical analyses are provided in the online supplementary material (Table A - Online Supplementary data).

\subsection{Clay mineralogy by $X$-ray diffraction}

A total of 18 samples were investigated for clay mineralogy using X-ray diffraction (XRD). The international procedure described by Moore and Reynolds (1997) was used to prepare the samples. X-ray diffractograms were performed on oriented mounts of noncalcareous clay-sized particles $(<2 \mu \mathrm{m})$ after a gentle crush to obtain finely powdered rock, decarbonation $(0.2 \mathrm{~N} \mathrm{HCl})$, deflocculation by successive washing with distilled water and extraction of the clay size fraction applying a Stockes law (1h35). For each sample, three XRD runs were analyzed after: air-drying (AD), ethylene-glycol solvation (EG) and heating at $490^{\circ} \mathrm{C}$ for two hours. Clay analyses were performed at the Biogeosciences Laboratory, UMR 6282, CNRS Université Franche-Comté, Dijon, France. Diffractograms were obtained using a Bruker D4 Endeavor diffractometer with CuKa radiations, LynxEye detector and $\mathrm{Ni}$ filter, under a $40 \mathrm{kV}$ voltage and a $25 \mathrm{~mA}$ intensity. The scanning range of the goniometer is $2.5^{\circ}$ to $28.5^{\circ} 2 \theta$. Relative proportions of each clay mineral species were calculated according to the area of the basal (001) reflections (Moore and Reynolds, 1997) on the three XRD diffractograms. Semi-quantification were achieved using the MacDiff 4.2.5 software (Petschick, 2000).

\subsection{Stable carbon and oxygen isotopes}

Lettéron, A., Hamon, Y., Founier, F., Séranne, M., Pellenard, P. and Jospeh, P., 2018. Reconstrcutnion of a saline, lacustrine carbonate system (Priabonian, St-Chaptes Basin, SE France): depositional models, paleogeogrpahix and paleoclimatic implications. Sedimentary Geology, 367, 20-47. 
A total of one hundred and five micro-powders of limestone were collected using a Dremel micro-drill tool. Stable carbon and oxygen isotope analyses were carried out at the Laboratory of Analytic Geochemistry of the Faculty of Earth Sciences at Utrecht University, The Netherlands. Carbonate powders were reacted with $103 \%$ phosphoric acid at $70^{\circ} \mathrm{C}$ using a Gasbench II connected to a ThermoFinnigan Five Plus mass spectrometer (Thermo Fisher Scientific). All values are reported in per mil relative to $\mathrm{V}$-PDB by assigning a $\delta^{13} \mathrm{C}$ and $\delta^{18} \mathrm{O}$ values of $+1.95 \%$ and $-2.20 \%$ to $\mathrm{NBS} 19$ and $-46.6 \%$ and $-26.7 \%$ o to LSVEC, respectively. Reproducibility and accuracy was monitored by replicate analyses of laboratory standards calibrated to NBS19 and LSVEC.

\section{Results}

\subsection{Review and synthesis of palynological data}

A review and synthesis of published palynological data from the Saint-Chaptes Basin (Gruas-Cavagnetto, 1973; Ellenberger, 1980; Alabouvette et al., 1983) has been performed and integrated in the present work. Palynological data are available from the whole section, except in the lowermost part. Two distinct floral assemblages can be identified from the available database: the FLA1 floral assemblage characterizes the lower part of the section (units U2 and U3), whereas the FLA2 floral assemblage has been identified in its upper part (units U4 to U6) (Fig. 5). Gruas-Cavagnetto (1973), Ellenberger (1980) and Alabouvette et al. (1983) identified 26 plant families, including pollens of gymnosperms and angiosperms and also spores of Pteridophytes (ferns).

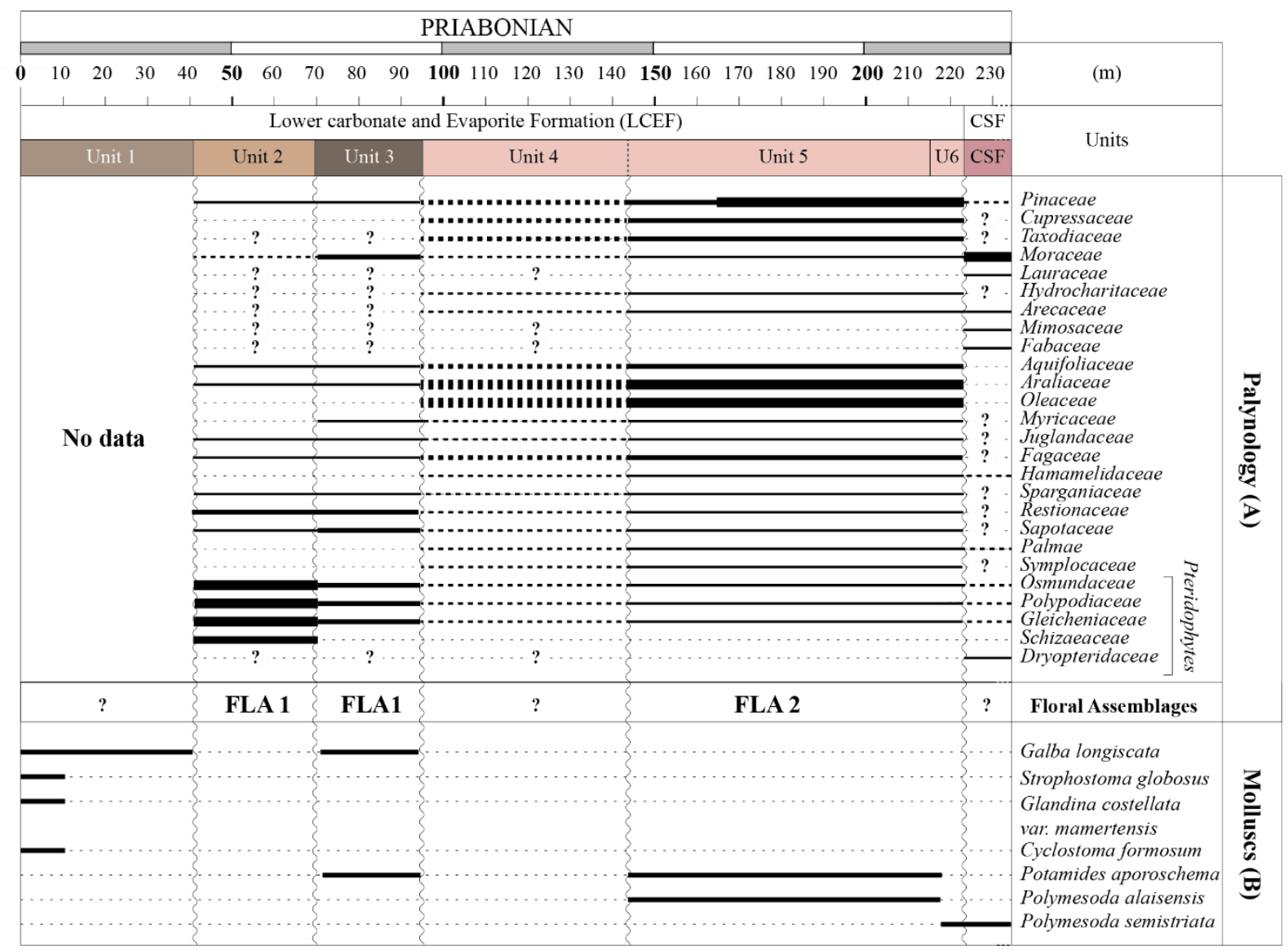

Fig. 5. Synthesis of palynological data after Gruas-Cavagnetto (1973); Ellenberger (1980); and Alabouvette et al., (1983) (A) and vertical distribution of molluscs after Depéret (1917) and Alabouvette et al. (1983) (B) in the Priabonian deposits of the Saint-Chaptes Basin.

Lettéron, A., Hamon, Y., Founier, F., Séranne, M., Pellenard, P. and Jospeh, P., 2018. Reconstrcutnion of a saline, lacustrine carbonate system (Priabonian, St-Chaptes Basin, SE France): depositional models, paleogeogrpahix and paleoclimatic implications. Sedimentary Geology, 367, 20-47. 


\subsubsection{Floral assemblage 1 (FLA1) - Units U2 and U3}

Paleovegetational material of FLA1 - Alabouvette et al., (1983) revealed a high concentration of Pteridophyte spores in unit U2 (Polypodiaceae, Osmundaceae, Gleicheniaceae). The hygrophilous flora was dominated by Schizaeaceae, closely related to the extant Lygodium species. The same study revealed some aquatic or semi-aquatic plants: Restionaceae (9\%) and Sparganiaceae (2\%). Spore concentration decreases from around $69 \%$ in unit U2 to $21 \%$ in unit U3. In unit U3, Sapotaceae (18\%) were identified in association with some Sparganiaceae and/or Arecaceae (=Palmae) (14\%). In units U2 and U3, spores are generally dominant whereas pollens are relatively scarce. However, some spore depleted samples revealed a lowland extra palustrine forests mainly composed by Pinaceae (14 to 20\%), tricolporate angiosperms (17 to 25\%) and Fagaceae (9\%).

Paleoenvironmental interpretation of the FLA1 floral assemblage - The abundance and diversity of ferns are indicative of a range of wet habitats including riverbanks, swamp, marsh or as understory in forests (Collinson, 2001; Kayseri-Özer, 2013). Schizaeaceae have a subtropical to tropical climatic distribution in contrast to the cosmopolitan dispersal of Osmundaceae and Polypodiaceae (Kayseri-Özer et al., 2014). Osmundaceae are considered to characterize freshwater wetlands and swamps (Collinson, 2002) or floodplain swamp forest under subtropical to warm temperate climate (Brown, 1962, Tidwell and Parker 1987). Gleicheniaceae, Polypodiaceae and Schizaeaceae-Lygodium assemblages characterize also swamp environments (Kayseri-Özer, 2013). Modern Lygodium are frequently assumed to be an epiphytic taxon colonizing pinaceae (Collinson, 2002). Sapotaceae thrive in evergreen and deciduous mixed forest (KayseriÖzer et al., 2014). Osmundaceae (semi-aquatic tree ferns), Polypodiaceae (mostly epiphytic, or aquatic, or terrestrial fern), Gleicheniaceae (aquatic to semi-aquatic fern), Schizaeaceae (climbing ferns) and Sparganiaceae (floating, aquatic to semi-aquatic monocotyledons) from the Rupelian of Turkey are related to freshwater lowland forests colonizing rivers and lake/swamp forests (Kayseri-Özer, 2013, Kayseri-Özer et al., 2014). The fern communities may have grown at the margins of, or within the swamp forests. Fagaceae, Pinaceae and tricolporate testify the development of evergreen and deciduous mixed and coniferous extra palustrine forests as observed in the Rupelian coal-bearing sediments of Turkey (Kayser-Özer, 2013). Osmundaceae often formed peat resulting in coal during the Mesozoic (Van Konijnenburg-Ban Cittert, 2002). The FLA1 assemblage from the Saint-Chaptes Basin is, therefore, interpreted to derive from a freshwater swampy area surrounding by an extra-palustrine humid forest.

\subsubsection{Floral assemblage 2 (FLA2) - Unit U4 to U6}

Paleovegetational material of FLA2 floral assemblage - In contrast to units U2 and U3, the concentration of spores founded in FLA2 is very low (2 to 3\%). Pinaceae (Pinus) and Taxodiaceae (Doliostrobus sternbergi) dominate the pollen assemblage (from 38 to 65\%). Some Oleaceae (4 to 7\%) and Aquifoliaceae (3 to 8\%) with rarer Araliaceae are minor components of FLA2 assemblage (Alabouvette et al., 1983).

Paleoenvironmental interpretation of the FLA2 floral assemblage - The FLA2 floral assemblage reflects a retreat of the swamp area. The elevated proportions of conifer pollens in FLA2 suggest drier substrate conditions compared to FLA1 (Alabouvette et al., 1983). In the Paris Basin, a renewal of existing floras by conifers occurred during the EarlyMid Priabonian (palynological zone 5 after Châteauneuf, 1980). As noted by Châteauneuf (1980), tectonic and relief creation could have favored such a renewal. Schuler (1990)

Lettéron, A., Hamon, Y., Founier, F., Séranne, M., Pellenard, P. and Jospeh, P., 2018. Reconstrcutnion of a saline, lacustrine carbonate system (Priabonian, St-Chaptes Basin, SE France): depositional models, paleogeogrpahix and paleoclimatic implications. Sedimentary Geology, 367, 20-47. 
evidenced in the Upper Rhine Graben significant climate changes during the Priabonian inferred from the vegetational changes: 1) Early Priabonian: dense evergreen, swamp and monsoon forests; 2) Middle Priabonian: floristic assemblages characterizing drier substrates; and 3) Late Priabonian: floristic assemblages with Pinaceae and microtherm species corresponding to colder and more humid climates.

Table 1. Summary of the main carbonate lithofacies identified in the Lower Carbonate and Evaporite Formation (LCEF) of the St-Chaptes Basin and associated paleoenvironmental interpretations.

\begin{tabular}{|c|c|c|c|c|c|}
\hline & Facies code & Lithofacies & Depositional environment & Wetland systems & Occurrences in units \\
\hline \multirow[t]{3}{*}{$\begin{array}{l}\text { Mixed terrigenous-carbonate } \\
\text { lacustrine association }\end{array}$} & MTC1 & Marlstone and argillaceous marlstone & $\begin{array}{l}\text { Perennial lake in profundal setting } \\
\text { (>10 m water depth) }\end{array}$ & Lacustrine & $\mathrm{U} 1, \mathrm{U} 2$ and $\mathrm{U} 6$ \\
\hline & MTC2 & $\begin{array}{l}\text { Quartz-rich peloidal } \\
\text { packstones-grainstone }\end{array}$ & $\begin{array}{l}\text { River mouth in a shallow perennial } \\
\text { lake }\end{array}$ & Lacustrine & $\mathrm{U} 2$ \\
\hline & MTC3 & $\begin{array}{l}\text { Fine-to-medium grained sandstone to } \\
\text { quartzose calcarenite }\end{array}$ & Subaqueous lacustrine delta shelf & Lacustrine & CSF \\
\hline \multirow[t]{8}{*}{ Salt lake carbonate association } & SLC1 & $\begin{array}{l}\text { Platy, dark-grey marlstone and } \\
\text { calcareous marlstone }\end{array}$ & Perennial lake & Lacustrine & U5 and U6 \\
\hline & SLC2 & $\begin{array}{l}\text { Bivalve-ostracodal platy } \\
\text { mudstone-wackestone }\end{array}$ & Perennial salt lake & Lacustrine & U5 and U6 \\
\hline & SLC3 & $\begin{array}{l}\text { Carbonate mudstone with leached } \\
\text { gypsum }\end{array}$ & Evaporitic lake & Lacustrine & U4 and U6 \\
\hline & SLC4 & Calcite raft-rich wackestone-packstone & Sheltered shallow salt lake & Lacustrine & U3 \\
\hline & SLC5 & Papyraceous argillaceous limestone & Shallow-water mudflat & Lacustrine & U5 \\
\hline & SLC6 & Peloidal packstone-grainstone & Shallow-water lake margin & Lacustrine & U5 and U6 \\
\hline & SLC7 & Oncolitic-Molluscan grainstone-rudstone & $\begin{array}{l}\text { Lacustrine slopes, } \\
\text { marginal-profundal lake transition }\end{array}$ & Lacustrine & U6 \\
\hline & SLC8 & Laminated bindstone (stromatolites) & Shallow-water salt lake margin & Lacustrine & U3 \\
\hline \multirow{4}{*}{$\begin{array}{l}\text { Floodplain/Palustrine } \\
\text { association }\end{array}$} & P1 & Lignites/organic-rich marlstone and clay & Fresh-water swamp & Palustrine & $\mathrm{U} 2$ and $\mathrm{CSF}$ \\
\hline & P2 & Silty clay with sideritic rhizocretions & Flood-plain/fresh-water swamp & Palustrine & U2 \\
\hline & P3 & $\begin{array}{l}\text { Brecciated-nodular and clotted-peloidal } \\
\text { limestone }\end{array}$ & Lake margin swamp & Palustrine to lacustrine & U6 \\
\hline & P4 & $\begin{array}{l}\text { Thinly-bedded oncolitic-bioclastic } \\
\text { grainstone }\end{array}$ & $\begin{array}{l}\text { Fluvial overbank in palustrine/flood } \\
\text { plain environment }\end{array}$ & Palustrine to lacustrine & $\mathrm{U} 2$ \\
\hline
\end{tabular}

\subsection{Clay mineralogy}

Clay mineral assemblages are mainly composed of R0 type illite-smectite mixedlayer (I/S R0) (20 to 94\%) very close to smectite features (14.5-15 $\AA$ for AD and 16.9-17.3 for EG) yet more or less well-crystallized and illite (6 to 42\%) (Fig. 6). In the lower part of the section (unit U1), the clay fraction evinces the only occurrence of palygorskite (up to $19 \%$ ) while I/S R0 are still dominant. It is worth mentioning that the first sample at the base of the series displays the highest concentration of illite (42\%) before decreasing to $~ 10 \%$. The interval above palygorskite occurrences (between 40 to 70 meters high, unit U2) contains chlorite (up to $4 \%$ ) followed-up by kaolinite (up to $8 \%$ ). Then I/S R0 and illite occur from 70 to 220 meters (Units U3-6) with some traces of chlorite (<4\%). The last 10 meters of the succession (Unit CSF) exhibit the highest concentrations of chlorite (16 to 22\%) and kaolinite (16 to 23\%). This kaolinite-chlorite clay assemblage appearance is associated with lesser I/S R0 (from 90\% to 30\%) and increased illite amount (from 10\% to 34\%).

\subsection{Depositional facies and paleoenvironmental interpretations}

The description of the carbonate facies is based on the modified Dunham classification system (Dunham, 1962) clarified by Lokier and Junaibi (2016). The supporting fabrics were thoroughly described. Fourteen lithofacies have been defined by lithology, dominant texture, sediment constituents, bedding, sedimentary structures, fossils and/or trace fossils (if present). The main sedimentological features and associated biota of the depositional facies identified in the Priabonian succession from the SaintChaptes Basin are summarized in Table 1. The complete lack of purely stenohaline biota, the mixture of fresh-water and brackish-water mollusc fauna (Alabouvette et al., 1983), the regular occurrence of characean gyrogonites and the presence of salinity-tolerant benthic 


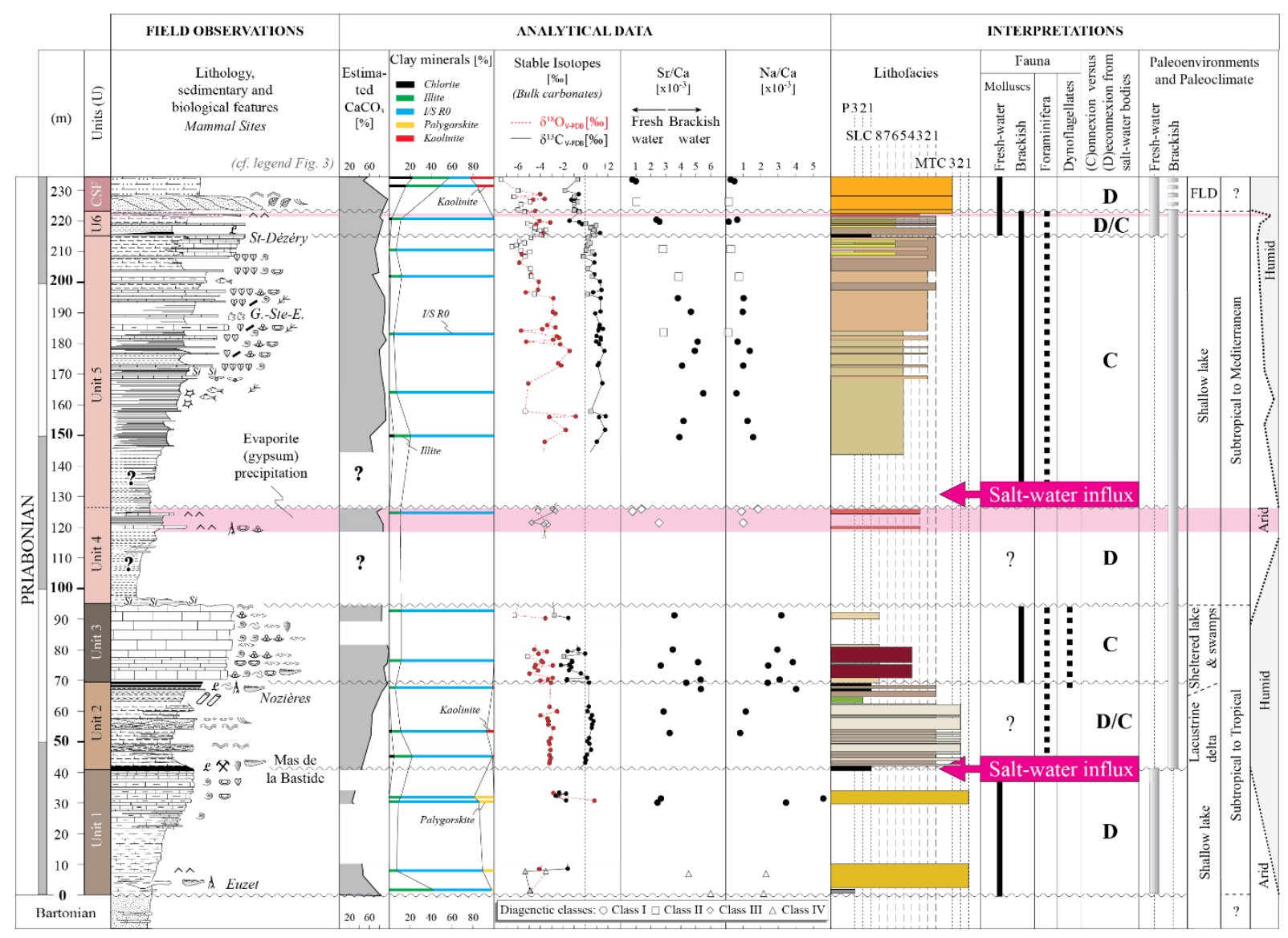

Fig. 6. Synthesis of lithostratigraphy, clay mineralogy, stable isotopes ( $\mathrm{C}$ and $\mathrm{O})$, trace elements ( $\mathrm{Sr} / \mathrm{Ca}$ and $\mathrm{Na} / \mathrm{Ca}$ ), biological markers of salinity and interpretations of the paleogeographic, paleoenvironmental and paleoclimatic evolution of the Priabonian succession from the Saint-Chaptes Basin. Please refer to the detailed legend of Fig. 4 for the artwork symbols of lithology, sedimentary and biological features. Abbreviations: CSF - Célas sandstone formation, DSS - deltaic silicilastic system.

foraminifera (e.g. Frédet, 1987) over the whole studied interval suggest non-marine environments of variable salinity. Lithofacies were grouped into three facies associations: 1) mixed terrigenous-carbonate lacustrine association; 2) salt lake carbonate association; and 3) palustrine association. They are defined in this section and then attributed to depositional settings on the basis of their elementary constituent, vertical stacking, lateral facies change and overall geometry.

\subsubsection{Mixed terrigenous-carbonate lacustrine association}

\section{Facies MTC1: marlstone and argillaceous marlstone}

Whitish to greyish marlstones and argillaceous marlstones are common in units U1, U2 and U6 (e.g. Fig. 7A). The carbonate content ranges from 25 to $50 \%$ and the clay fraction is dominated by I/S RO (80 to 90\%) with minor proportions of illite $(<10 \%)$. Palygorskite is present in unit U1 (Fig. 6). The micro and macrofauna is extremely rare in this facies. Rare gastropods are present in unit U1. MTC1 intervals are generally massive or organized into decimeter thick beds. 

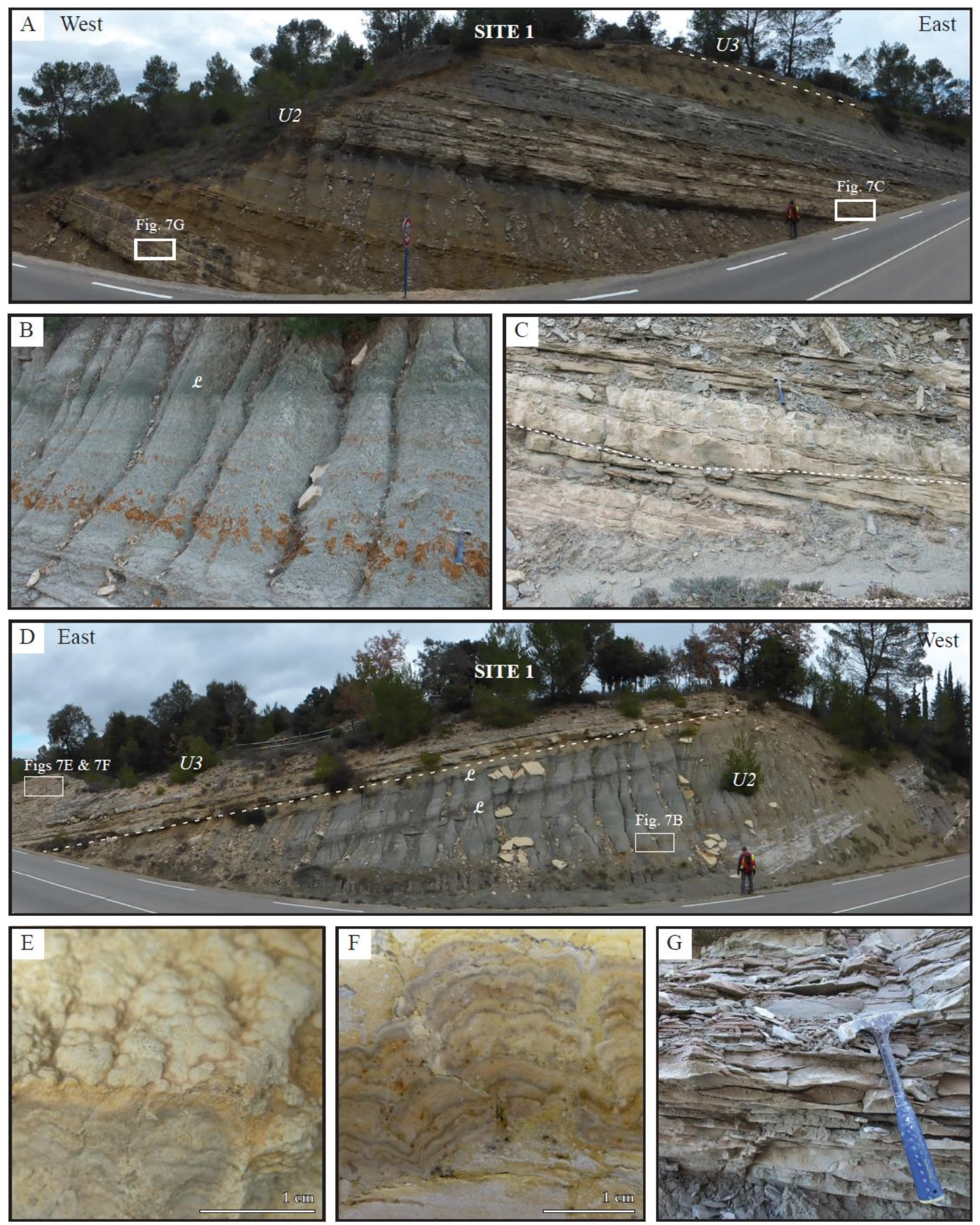

Fig. 7. Units U2 and U3: Macroscopic sedimentary features: (A) SITE 1 outcrop (northern side of the D981 road) showing Unit U2 and base of Unit U3 deposits. (B) Wave-formed structures in quartz-rich peloidal packstone-grainstone (MTC2 facies). (C) Alternation of $\mathrm{cm}$-dm thick beds of fine-grained quartz-rich peloidal grainstone (MTC2) and marlstone (MTC1); the dashed line indicates the erosive nature of some MTC2 beds. (D) SITE 1 outcrop (southern side of the D981 road, the dashed line highlights the boundary between the soft mixed terrigenous-carbonate unit U2 and the massive carbonate unit U3; lignite beds are indicated (L). (E and F) Smooth wavy laminae and cauliflower-like structure at the top of a bindstone limestone bed (SLC8 facies). (G) Bindstone showing pustular laminae (facies SLC8). (H) Soft sideritic layer from the uppermost part of the unit $\mathrm{U} 2$.

Lettéron, A., Hamon, Y., Founier, F., Séranne, M., Pellenard, P. and Jospeh, P., 2018. Reconstrcutnion of a saline, lacustrine carbonate system (Priabonian, St-Chaptes Basin, SE France): depositional models, paleogeogrpahix and paleoclimatic implications. Sedimentary Geology, 367, 20-47. 

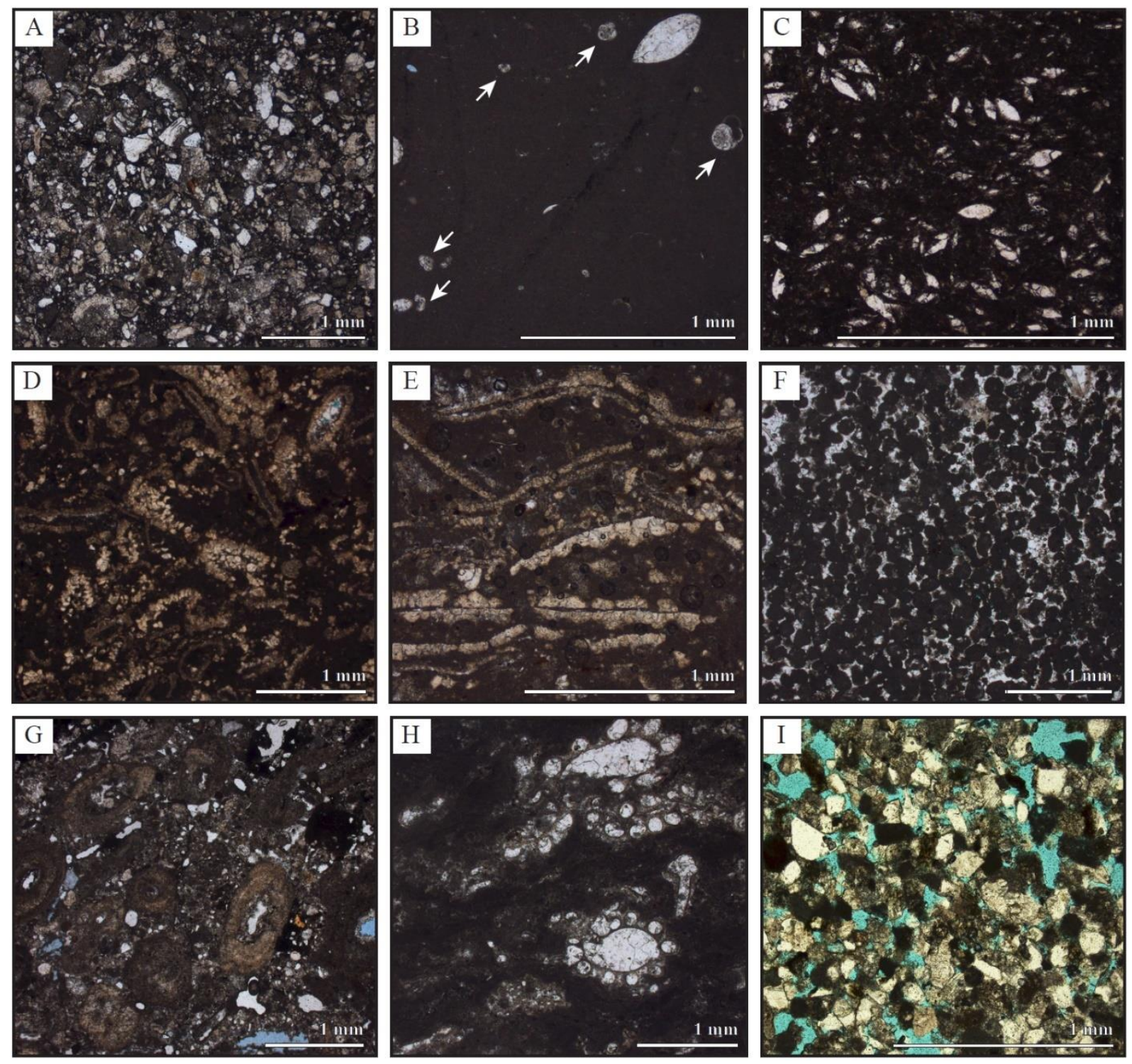

Fig. 8. Thin-section photomicrographs. (A) Fine-grained quartz-rich peloidal packstone-grainstone (facies MTC2). (B) Foraminifera-ostracodal mudstone-wackestone (facies SLC2), white arrows show small benthic foraminifera. (C) Homogeneous micrite with sparse, leached gypsum crystals (facies SLC3). (D) Wackestone-packstone containing various proportions of subcylindrical calcitic crusts generally composed of one layer of equigranular calcite (facies SLC4). (E) Packstone with flat, random length, microcrystalline, equigranular calcite rafts (facies SLC4). (F) Well-sorted, peloidal micrograinstone (facies SLC6), note the intergranular porosity occluded by sparry, blocky calcite. (G) Poorly sorted oncolitic grainstone (facies P4). (H) Micritic laminae draping characean gyroponites characteristic of laminated bindstone texture (facies SLC8). (I) Fine-grained Qz-sandstones with abundant micritic grains (peloids) and devoid of intergranular cement (facies MTC3).

Paleoenvironmental interpretation - The lack of subaerial exposure features (desiccation, pedogenesis) within MTC1 facies suggests a deposition in a perennial water body. The scarcity of biological elements may be related to profundal lake setting $(>10 \mathrm{~m}$ water depth) or to unfavorable conditions for benthos development (low oxygenation, low nutrient supply and/or variable salinity). 
MTC2 facies is reported from the lower part of unit U2 only. It consists of a mixture of carbonate allochems (dominantly peloids with rarer ostracods and molluscs) and very fine to fine-grained quartz particles (up to 25\%) that are set in a matrix made of carbonate silt particles, micrite and clays (Fig. 8A). The clay fraction is dominantly composed of I/S R0 type ( 80\%) with minor proportions of illite (9 to $17 \%)$, kaolinite $(<8 \%)$ and chlorite $(<5 \%)$. The carbonate content typically ranges from 60 to $70 \%$. MTC2 deposits are organized into decimeter thick strata displaying symmetric ripple structures with smooth edges that are attributed to wave-related structures (Fig. 7G). MTC2 deposits are interbedded within MTC1 marlstones and argillaceous marlstones. More rarely, some beds exhibit an erosive base (Fig. 7C).

Paleoenvironmental interpretation - The lack of subaerial exposure evidence within MTC2 intervals suggests a deposition in a perennial subaqueous environment. The high content in sand-sized quartz particles suggests the vicinity of a river mouth. The waveformed structures suggest a shallow-water environments subject to surface wave action.

\section{Facies MTC3: Fine-to-medium grained sandstones to quartzose calcarenite}

Facies MTC3 corresponds to the basal deposits of the Célas Sandstone Formation (CSF) in the Saint-Chaptes Basin. It consists of 1 to $10 \mathrm{~cm}$-thick flat-based beds of fine-tomedium grained sandstones or quartzose calcarenites interbedded within silty marlstones. Allochems are essentially composed of quartz grains (40 to 60\%) and calcitic peloids (40 to $60 \%$ ). Abundant macroporosity indicates minor cementation or, by contrast, intense dissolution (Fig. 8I), rock cohesion is mainly due to compaction. MTC3 deposits are usually cross-bedded and the top of the beds often exhibits asymmetric ripples.

Paleoenvironmental interpretation - The lack of subaerial exposure evidence within MTC3 along with its association with silty marls suggest a deposition in a perennial subaqueous environment. The occurrence of thin beds of cross-bedded sandstone or quartzose calcarenite within profundal silty marl deposits may suggest an export by fluvial currents of sand material from the lake margin area toward the toe of a lacustrine delta.

\subsubsection{Salt lake carbonate association}

\section{SLC1 facies: Platy dark-grey marlstone and calcareous marlstone}

Platy dark grey marlstones and calcareous marlstones are common in the units U5 and U6 (e.g. SITE 3 - Figs 9B and 9C). The carbonate content ranges from 50 to $75 \%$ and the clay fraction is dominated by interstratified I/S/R0 (80 to 90\%) with minor proportions of illite (10 to $20 \%$ ) (Fig. 6). They consist of thinly-bedded mudstones with $\mathrm{mm}$ to $\mathrm{cm}$-thick beds with planar laminations and flat surfaces (Fig. 9C). Planar laminations are commonly underlined by variations in organic-matter content. Well-preserved fossil fishes are common, as well as coaly plant remains. Molluscs are rare and mainly consist of smallsized bivalves (Polymesoda).

Paleoenvironmental interpretation - The lack of subaerial exposure evidence associated to well-preserved laminae suggest a deposition in a subaqueous, low hydrodynamism environment. The occurrence, although rare, of bivalves such as Polymesoda suggests relatively shallow water-depths ( $<10 \mathrm{~m}$ : Morton, 1983) in brackishwater conditions (Esu and Girotti, 2010). The preservation of organic matter suggests relatively poorly-oxygenated waters. The water salinity and low-oxygen conditions, rather 

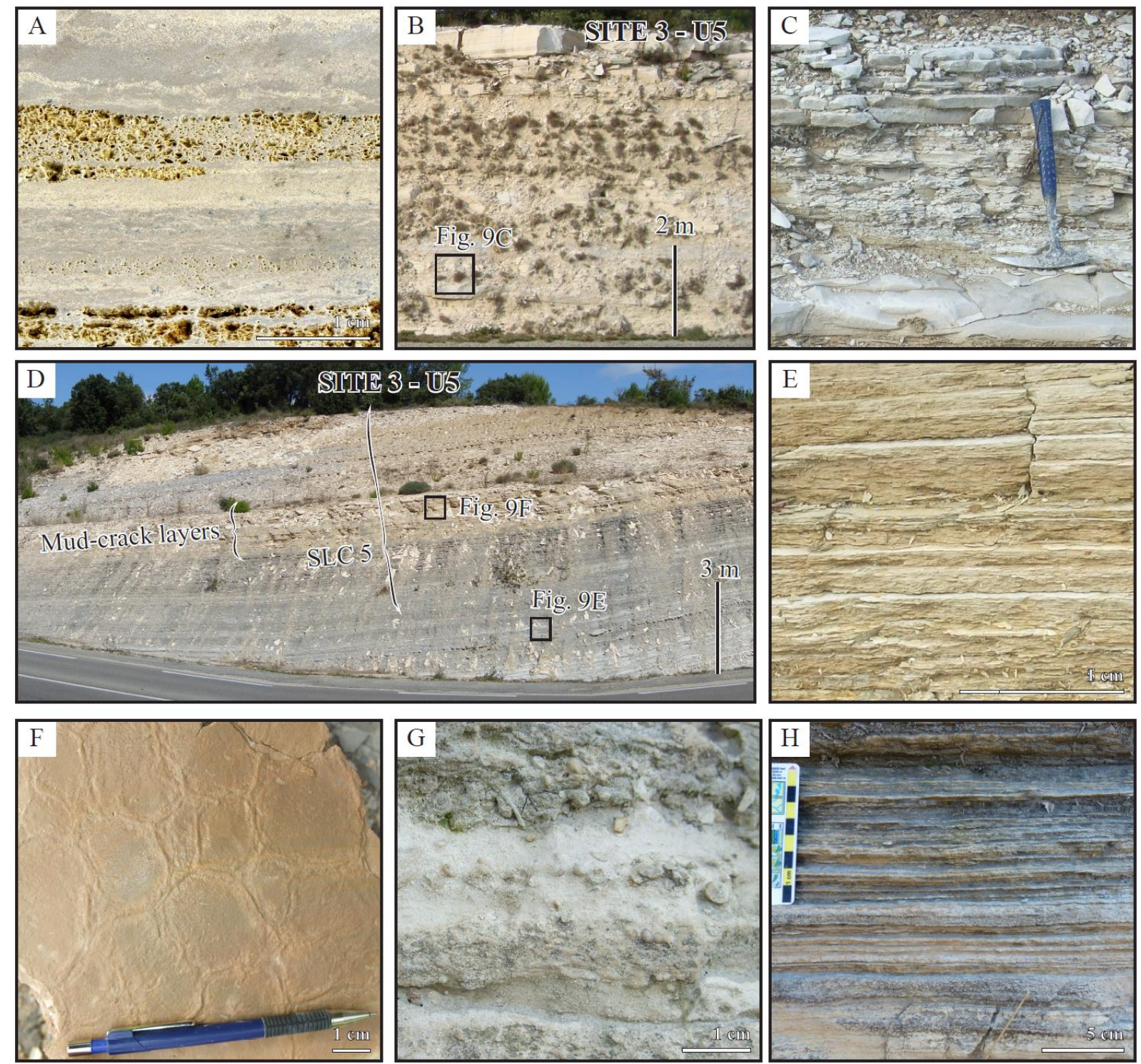

Fig. 9. (A) Alternating mudstone-peloidal packstone and laminae with fine-grained dissolved gypsum crystals (facies SLC3). (B) SITE 3 outcrop showing the upper part of unit U5. (C) Bivalve-ostracodal, platy mudstone-wackstone (facies SLC2). (D) Macroscopic aspect of laminations within papyraceous argillaceous limestones (facies SLC5). (E) SITE 3 outcrop (lower part of unit U5), within papyraceous argillaceous limestones. (F) Shrinkage cracks on the surface of papyraceous limestones (see location on Fig. 9H). (G) Detail of coarse-grained poorly sorted, oncolitic-bioclastic grainstone-rudstone (facies SLC7) laminae within silty marlstones. (H) Alternating beds of oncolitic-bioclastic grainstone-rudstone (SLC7 facies) within marlstones (MTC1).

than water-depth, are likely responsible for the lack of bioturbation and limited benthos on the lake bottom (Gierlowski-Kordesch and Rust, 1994).

\section{$\underline{\text { SLC2 facies: Bivalve-ostracodal platy mudstone-wackestone }}$}

Bivalve-ostracodal platy mudstones are common in units U5 and U6. The carbonate content is high (>90\%) and it consists of a mudstone to wackestone with bivalves (Polymesoda), ostracods and benthic foraminifera (Fig. 8B). Centimeter-thick beds devoid of internal lamination characterize the latter deposits. Their whitish color suggests a very low organic-matter content. The gastropod Potamides may occur in SLC2 limestones.

Lettéron, A., Hamon, Y., Founier, F., Séranne, M., Pellenard, P. and Jospeh, P., 2018. Reconstrcutnion of a saline, lacustrine carbonate system (Priabonian, St-Chaptes Basin, SE France): depositional models, paleogeogrpahix and paleoclimatic implications. Sedimentary Geology, 367, 20-47. 
SLC2 facies may form up to 10 m-thick intervals interbedded within peloidal grainstone (SLC6).

Paleoenvironmental interpretation - As for the SLC1 facies, the lack of subaerial exposure evidence (desiccation, pedogenesis) and the monotonous, regularly-bedded succession of platy limestones in SLC2 intervals are indicative of perennial subaqueous environments. The common and regular occurrence of benthic foraminifera as well as the Potamides-Polymesoda molluscan assemblage, are indicative of brackish, oligomesohaline waters (Daley, 1972). In addition, Polymesoda needs water temperatures between $18^{\circ} \mathrm{C}$ and $32^{\circ} \mathrm{C}$ (Morton, 1983). The relative abundance of the biota and the poor preservation of organic-matter suggest well-oxygenated waters. The low clay content compared to SLC1 facies could be related to higher rates of carbonate mud production or a lowering in detrital input. As a result, SLC2 facies seemingly deposited in a saline (dominantly oligo-mesohaline) perennial lake, in warm $\left(>18^{\circ} \mathrm{C}\right)$, well-oxygenated and shallow $(<10 \mathrm{~m})$ waters.

\section{SLC3 Facies: Carbonate mudstone with leached gypsum}

SLC3 facies occurs in unit U4 and at the top of unit U6. It consists of alternating laminated carbonate mudstone and peloidal (fecal pellets) grainstones (carbonate content $>80 \%$ ) with rare ostracods and comprising up to $1 \mathrm{~cm}$-thick layers of lenticular-tabular gypsum (dissolved lenses from 0.1 to $2 \mathrm{~mm}$ length) (Fig. 9A). Gypsum crystal are embedded within a homogeneous micrite with rare ostracods (Fig. $8 \mathrm{C}$ ). The dissolution voids after gypsum dissolution may remain empty, filled with sparry calcite or micrite cements. Dark, organic matter-rich laminae are common in SLC3 facies.

Paleoenvironmental interpretation - The biological content dominated by ostracods, the lack of exposure evidence and the common association with peloidal grainstones (fecal pellets) suggest a shallow, perennial water body. Lens-shaped gypsum is commonly reported from soil environments (Cody, 1979), the absence of mudcracks and desiccation features within the sediment, suggest a subaqueous formation of the gypsum in a hypersaline lake environment rather than in intertidal or subaerial environments (Playá et al., 2007; Mees et al., 2012). The wavy morphology of the micritic laminae overlying the gypsum layers could be related to the draping of the uneven top gypsum surface but may also reflect displacive deformation due to gypsum growth within the sediment. Early gypsum formation within muddy sediments below the sediment-water interface has been reported in modern mesohaline coastal salt lakes from the south of France (Lévy, 1972). Thus, the SLC3 facies likely deposited in a shallow perennial lake under evaporitic conditions.

\section{$\underline{\text { SLC4 facies: Calcite raft wackestone-packstone }}$}

It consists of mud-rich carbonate deposits comprising various proportions of crystalline flakes (Figs 8D and 8E), ostracods and small benthic foraminifera. This facies were only found in unit U3. They are organized into decimeter thick isopachous beds of tight limestones (Fig. 7D). Subhorizontal, slightly wavy cryptolaminations (commonly inframillimetric) are common. Flat crystalline flakes have been described as calcite rafts (Folk et al., 1985; Pentecost and Viles, 1994; Taylor et al., 2004; Gandin and Capezzuoli, 2014), paper-thin rafts (e.g. Guo and Riding, 1998) or floating mats (Archer et al., 1989). Calcite rafts (Folk et al., 1985; Guo and Riding, 1998; Gandin and Capezzuoli, 2014) are made of a micrite film in the center, lined on one or both surfaces by microcrystalline, equigranular calcite (Fig. 8E). SLC4 facies may also contain various proportions of subcylindrical calcitic crusts generally composed of one layer of equigranular calcite of similar morphology as 
the ones of calcitic rafts (Fig. 8D). Such structures likely represent calcitic encrustations around macrophytes (e.g. Guo and Riding, 1998). Oncoids are also common within calcite raft wackestone-packstone. The cortex of the oncoids typically displays filamentous structures. The associated molluscan assemblage is dominated by the gastropod Potamides aporoschema.

Paleoenvironmental interpretation - Calcite rafts are predominant in sheltered environments with standing-water conditions, in area with marked dry and wet seasons (Taylor et al., 2004). Rafts are well known from thermal and non-thermal waters: cave pool, lake shorelines when the lake water $\mathrm{pH}$ increases, standing-water conditions in fluvial systems and hot spring pools (Folk et al., 1985; Taylor et al., 2004). They precipitated at the surface of carbonate-rich stagnant water bodies where degassing of $\mathrm{CO}_{2}$ and/or evaporation occurs (Folk et al., 1985; Gandin and Capezzuoli, 2014). Calcite rafts are commonly broken and tilted by hydrodynamism induced by several sources of turbulence, such as biological activity, currents or wind and/or by the pressure exert by gas bubbles on the solid crystalline plates (Gandin and Capezzuoli, 2014). Brackish-water conditions are suggested by the common occurrence of benthic foraminifera and further documented by the gastropod Potamides indicative of saline-water environments (Macpherson and Gabriel, 1962; Plaziat, 1993; Kowalke, 2006).

\section{SLC5 facies: Papyraceous argillaceous limestone}

SLC5 facies occurs in unit U5 (SITE 2 - Fig. 9D). It consists of very thinly-laminated $(\sim 0.1 \mathrm{~mm})$ argillaceous mudstones (carbonate content: 75 to 90\%) commonly affected by desiccation cracks (Figs 9E and 9F). In such papyraceous argillaceous limestones, wellpreserved fossil fishes are common as well as insects together with the gastropod Potamides aporoschema.

Paleoenvironmental interpretation - The common and regular occurrence of desiccation cracks within SLC5 deposits suggests a deposition in a very shallow lake margin prone to repeated subaerial exposition. The preservation of desiccation cracks and the lack of pedogenic features within the papyraceous deposits are indicative of shortterm (seasonal?) exposures in a relatively dry climatic setting. Modern descendants of the fish Hemitrichas usually live in brackish to hypersaline waters but their dominance pinpoints temporary hypersaline conditions consistent with a dry climate and significant seasonal evaporation (Reichenbacher, 2004).

\section{SLC6 facies: Peloidal packstone-grainstone}

It consists of a packstone-grainstone with abundant peloids, rare ostracods and benthic foraminifera (Fig. 8F), forming massive 10 to $20 \mathrm{~cm}$ thick beds, devoid of significant sedimentary structure. Peloidal packstone-grainstone are common in units U5 and U6 and are commonly found alternating with bivalve-ostracodal mudstones (SLC2). The mollusc fauna is dominated by the Potamides-Polymesoda association. Peloids do not show evidences of significant mechanical or chemical compaction. Their respective uniformity (shape and size) strongly suggests a fecal origin (fecal pellets) (e.g. Freytet and Verrecchia, 2002) (Fig. 8F). The intergranular porosity is generally entirely occluded by sparry (blocky) calcite cements or by micrite matrix.

Paleoenvironmental interpretation - As for SLC1 facies, the lack of subaerial exposure evidence (desiccation, pedogenesis) and their association with the platy limestones SLC2 suggest a deposition in a perennial water body. The common occurrence of benthic foraminifera as well as the Potamides-Polymesoda molluscan assemblage are indicative of warm, shallow, oligo-mesohaline waters (Daley, 1972; Morton, 1983). As for 
SLC2 facies, the poor preservation of organic-matter suggest well-oxygenated waters. Lacustrine calcitic fecal pellets are commonly interpreted to be produced by crustaceans (Finkelstein et al., 1999) but they are also known to be formed by worms or gastropods (Flügel, 2010). The common grainstone texture of SLC6 facies may not be related to high energy conditions but rather to the development of dense populations of pelletproducing organisms. SLC6 facies presumably occured in a salt (dominantly oligomesohaline) perennial lake, in warm $\left(>18^{\circ} \mathrm{C}\right)$, well-oxygenated and shallow $(<10 \mathrm{~m})$ waters.

\section{SLC7 facies: Oncolitic-molluscan grainstone-rudstone}

It is documented in unit U6 as decimeter-to meter thick crudely-laminated beds (Fig. 9H) intercalated within profundal lacustrine marlstones and argillaceous platy limestones (MTC1 and SLC1 facies) commonly displaying gravity-related structures. The base of the oncolitic beds is erosive. Oncoids are generally coarse-grained (typically 1 to 5 $\mathrm{mm}$ in diameter) and the nuclei generally consist of mollusc fragments (Fig. 9G). The cortex is made of continuous and relatively isopachous micrite laminae.

Paleoenvironmental interpretation - Lacustrine oncoids are known to be characteristically concentrated in shallow, nearshore areas with moderate wave or current agitation and where detrital or shell material is available to form the nuclei (Hargrave et al., 2014; Lanès and Palma, 1998). The occurrence of thin oncoid-rich beds within profundal lacustrine deposits may be interpreted as being related to an export of the oncoids that formed in the shallow lake margin into the deep lake. The erosive base of the beds and the presence of slumps in the embedding marls suggest that the oncoids have filled slope gullies at the transition between the shallow lake margins and profundal lake environments.

\section{$\underline{\text { SLC8 facies: Laminated bindstone (stromatolites) }}$}

This facies has been defined as laminated limestones with bindstone texture that are dominantly made of sub-horizontal, wavy, clotted peloidal micrite laminae $(100 \mu \mathrm{m}$ to $1 \mathrm{~mm}$ thick) alternating with variably continuous microsparite to sparite laminae (up to 0.5 $\mathrm{mm}$ thick). In the Saint-Chaptes Basin, laminated bindstones exhibit exclusively low-relief, planar morphologies. Dessication cracks are common. Wavy micritic laminae are commonly found draping mollusc shells, ostracods or characean gyrogonites (Fig. 8H). Two distinct morphologies of laminae have been evidenced: smooth wavy laminae in unit U6 or pustular laminae in unit U3 (Figs 7E and 7F). The microbial origin of such laminae is suggested by small-scale corrugations and by preferential thickening over small irregularities of the substrate. Characean thalli and molluscs (Potamides, Polymesoda, Galba) are commonly associated with laminated bindstones.

Paleoenvironmental interpretation - Planar-laminated bindstones (stromatolites) are indicative of very shallow-water environments (e.g. Wattine et al., 2003). The shallowwater conditions for planar-laminated bindstone deposition (probably less than a few meters) is supported by the molluscan assemblage and by the abundance of characean gyrogonites and thalli. Stromatolites are reported from freshwater to hypersaline lakes (e.g. Talbot and Allen, 1996). The brackish-water affinity of the molluscan assemblage suggests, therefore, deposition in the very shallow (less than few meters) margins of a salt lake. 


\subsubsection{Flood-plain and palustrine association}

\section{P1 facies: Lignite/organic-rich marlstone and clay}

Depending on the concentration of organic matter, the lithology varies from lignite to organic-rich marlstones whose contact is typically transitional (Fig. 7D). The lignitebearing strata are organized into decimeter-thick, massive or parallel laminated beds. Root traces are common in lignite beds and organic-rich marlstones and clays. Organicrich marlstones contain a variable proportion of macro- and microfossils including freshwater gastropods with preserved aragonite (Galba, Planorbis), ostracods, charophytes, phytoclasts, vertebrate remains and rare foraminifera. Three significant lignite intervals occur in the Saint-Chaptes Basin: 1) in the topmost part of the unit U2 (2.2 m at Mas de la Bastide mine); 2) in the topmost part of the unit U3 (Serre de Cauvel Unit, $\sim 1 \mathrm{~m}$ ); and 3) at the bottompart of the unit U6 $(\sim 1 \mathrm{~m})$. Lignites are composed of water $(17.9$ to $24.5 \%)$, plant material (34 to $34.8 \%$ ), ashes (6.4 to $11.5 \%$ ), fixed carbon (31 to $34.5 \%$ ) and sulfur (5.8 to 6.8\%) (Alabouvette et al., 1983).

Paleoenvironmental interpretation - Lignites result from the accumulation of organic matter in anoxic conditions. Parallel laminations suggest a low-energy depositional environment (e.g. coastal marsh; Samanta et al., 2016). Such an interpretation is also supported by the common occurrence of pedogenic features (root traces) within or above the lignite beds.

\section{$\underline{\text { P2 facies: Silty clay with sideritic rhizocretions }}$}

Decimeter to meter thick beds of silty clay with sideritic rhizoconcretions are interbedded within the lignite/organic-rich marlstones (P1) in the upper part of unit U2 (Figs 7D and 7B). P2 facies is characterized by the occurrence of reddish-orange colored sideritic concretions (Fig. 7B). Two types of concretions have been identified: 1) scattered, large (up to $15 \mathrm{~cm}$ wide), friable and irregular to subcylindrical nodular concretions, preferentially vertically-oriented; and 2) narrow ( $<2 \mathrm{~cm}$ width), elongated (up to $15 \mathrm{~cm}$ long) vertical structures with central moulds. Vertical concretions are randomly spreading within the silty clays, typically above the friable nodular concretions.

Paleoenvironmental interpretation - The association of nodular and cylindrical concretions with hollow center is commonly associated with root-related features, formed in suboxic meteoric phreatic zone (Bojanowski et al., 2015). The roots penetrateddeeply into a waterlogged soil. Sideritic beds have been associated to backswamp paludal deposits close to meandering streams in an alluvial floodplain with frequent overflows (Tidwell and Parker, 1987).

\section{Facies P3: Brecciated-nodular and clotted-peloidal limestone}

This facies corresponds to limestones with breccia-like texture and is characterized by the occurrence of the following features: 1) nodular fabrics; 2) clotted fabrics with micritic peloids; 3) grains coated by micrite; and 4) wrinkled microcracks. Root traces are also commonly observed in facies P3. Two dominant textures are identified: brecciatednodular limestones and clotted-peloidal limestones. Brecciated-nodular limestones are carbonate microbreccias with poorly sorted (10 to $1000 \mu \mathrm{m})$, angular to subangular micritic elements set within a micritic matrix or cemented by sparry (blocky) calcite cements, exhibiting common root traces and wrinkled microcracks. Clotted-peloidal limestones are wackestone to packstone with subrounded micritic peloids (50 to $100 \mu \mathrm{m}$ in diameter) and coated intraclasts. Circumgranular cracks are common around intraclasts. 
Paleoenvironmental interpretation - The brecciated-nodular and clotted-peloidal textures are known to characterize a typical facies association of palustrine environments at the margin of shallow lakes with fluctuating lake level (Freytet, 1973). The clottedpeloidal texture is generally assigned to a more advance degree of pedogenic transformations compared to the brecciated-nodular limestones (Armenteros et al., 1997). The development of palustrine carbonates is known to mainly characterize semi-arid to subhumid environments (Alonso-Zarza, 2003).

\section{P4 facies: Thinly-bedded oncolitic-bioclastic grainstone}

It consists of poorly sorted grainstones to rudstones with oncoids $(0.1$ to $5 \mathrm{~mm}$ in diameter), molluscs, ostracods and benthic foraminifera (miliolids and textulariids). It occurs in units U2 as decimeter thick lenticular beds (lense lateral extension $<100 \mathrm{~m}$ ) interbedded within organic-rich silty marlstones with root traces (P1 facies). No erosional feature is present at the base of the oncoid-rich beds. Oncoids are generally small-sized $(<2 \mathrm{~mm})$ and the nucleus of the oncoids is generally not preserved and occurs as molds (Fig. 8G). The rounded sections of the nucleus and the elongated shape of most of the oncoids suggest that the cortex developed around plant stems. The cortex is generally made of regular, continuous, relatively isopachous micrite laminae.

Paleoenvironmental interpretation - Oncoid morphology is strongly influenced by the hydrodynamic settings. Oncoids with continuous micrite layers are indicative of incessant wave activity or agitated conditions (Dahanayake, 1977; Lanès and Palma, 1998). The grainstone texture also support agitated waters. The occurrence of thin, non-erosivebased, oncoid-rich lenses within palustrine/flood plain deposits may be interpreted as being related to overbank processes that caused the spread and accumulation of fluvial oncoids over the floodplain (Arenas et al., 2007). However, the common occurrence of well-preserved benthic foraminifera suggests an influence of lacustrine salt water during deposition of oncoid-rich beds.

\subsection{Elemental and isotopic geochemistry}

\subsubsection{Carbon and oxygen stable isotopes}

Geochemical data including carbon and oxygen stable isotopes have been reported in the Table B. In order to extract the primary paleoenvironmental signal of bulk rock carbon and oxygen isotope measurements from the diagenetic overprint, the rock samples have been classified into four diagenetic classes: 1) samples devoid of pedogenic overprint and with low $(<5 \%)$ sparry calcite cement content and no micrite cement (class I); 2) samples devoid of pedogenic overprint and with high sparry calcite cement content (class II); 3) samples with pedogenic features such as root traces, brecciation, grain micritization, pervasive microsparitization/sparitization (class III); and 4) samples with microsparitic calcite infilling intergranular pore spaces (class IV).

In the unit U1 (Fig. 10A), basal limestones (Euzet vertebrate-rich horizon - EUZ sample in Figure 4) belong to diagenetic class III (pedogenic carbonates) and exhibit highly negative $\delta^{13} \mathrm{CV}$-PDB values (from -3.46 to $-4.84 \%$ ) with $\delta^{18} \mathrm{OV}-\mathrm{PDB}$ values ranging from -4.94 to $-5.35 \%$. Overlying silty marls (diagenetic class I) exhibit strong variations in $\delta^{18} \mathrm{OV}-\mathrm{PDB}$ (from -4.09 to $+0.89 \%$ ) whereas $\delta^{13} \mathrm{CV}$-PDB remains negative and display low fluctuations (from -1.58 to $-2.65 \%$ ). 
$\mathbf{A}$

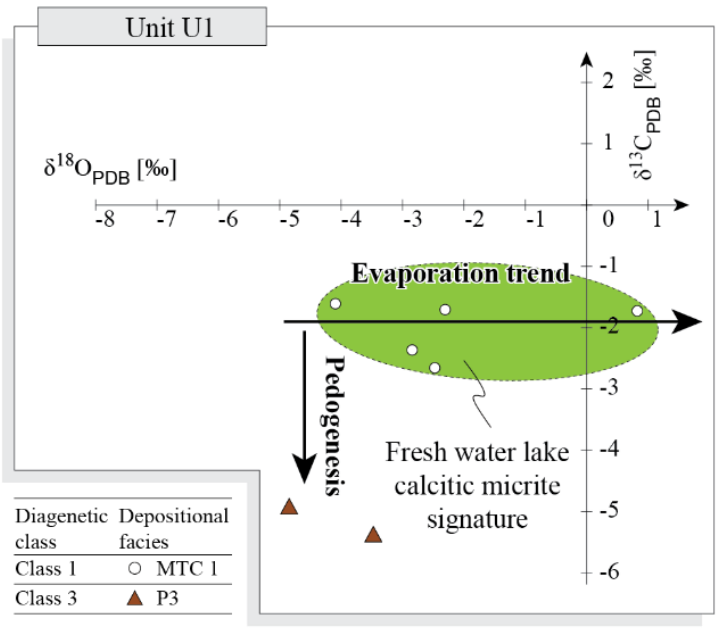

$\mathbf{C}$

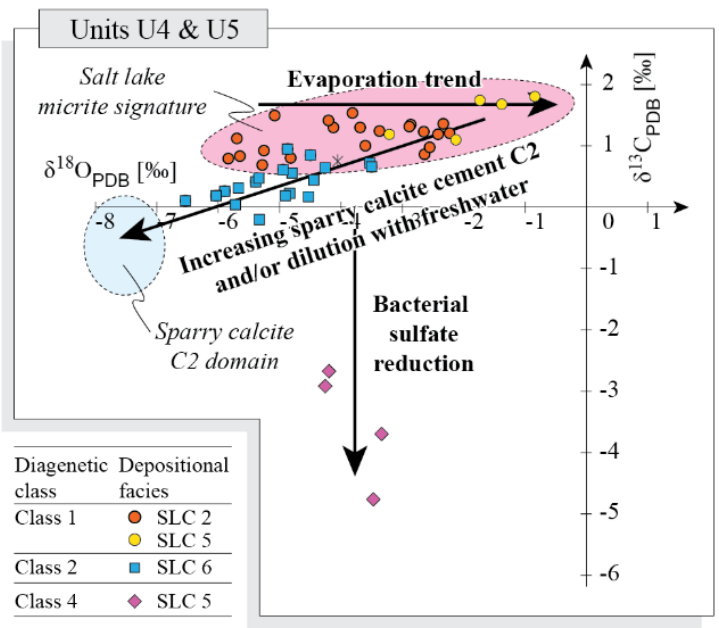

B

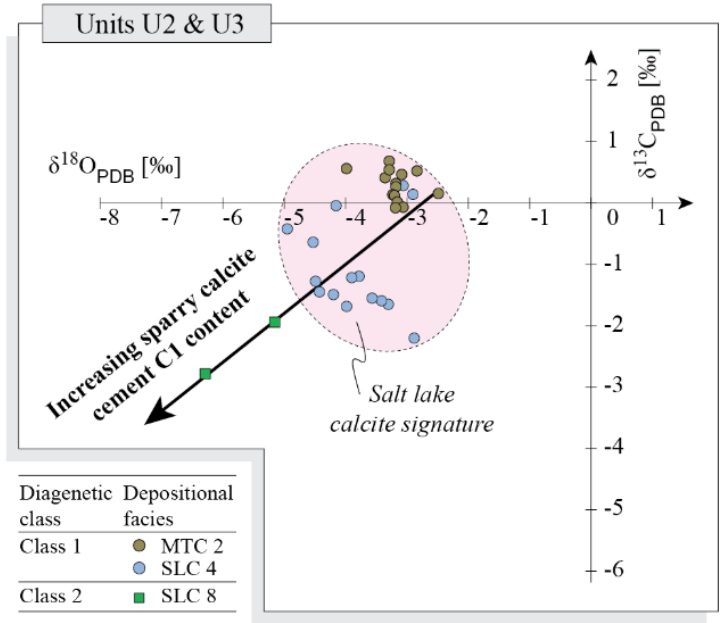

D

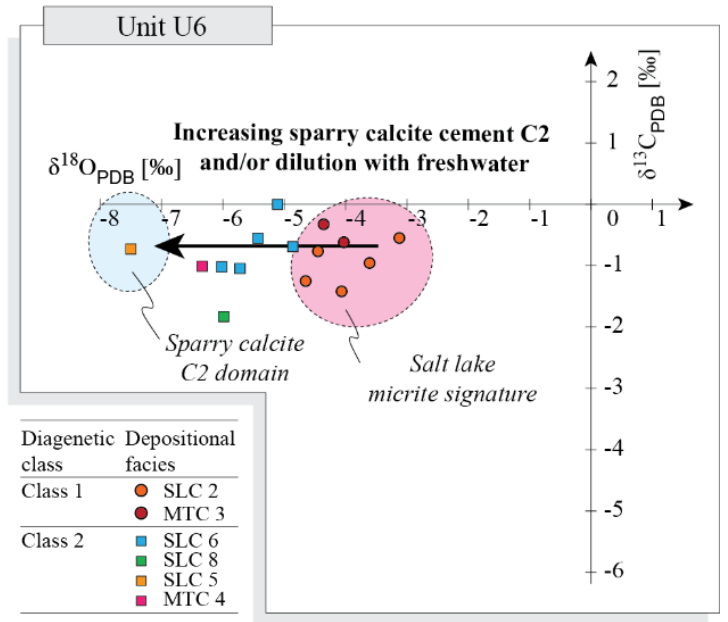

Fig. 10. Stable carbon $\left(\delta^{13} \mathrm{CV}-\mathrm{PDB}\right)$ and oxygen $\left(\delta^{18} \mathrm{OV}\right.$-PDB) isotope cross-plots: $(A)$ unit $U 1,(B)$ units $U 2$ and $U 3$, (C) units U4 and U5, (D) unit U6. Symbols for samples represent the depositional facies (cf. Table 1) and the diagenetic classes (cf. section: carbon and oxygen stable isotopes). Values are expressed in per mil (\%o) and are relative to V-PDB. (For interpretation of the references to color in this figure legend, the reader is referred to the web version of this article.)

In the unit U2, all measured samples correspond to quartz-rich peloidal-oncoidal packstone (facies MTC2) belonging to the diagenetic class I (Table B). The $\delta^{13} \mathrm{CV}$-PDB is mostly positive and exhibits very low variations (from -0.03 to $+0.71 \%$ ) whereas the $\delta^{18} \mathrm{OV}$ PDB ranges from -3.98 to $-2.50 \%$ (Fig. 10B).

In the unit U3, class I samples (SLC4 facies: calcite raft-rich packstone) display negative to moderately positive $\delta^{13} \mathrm{CV}$-PDB values (from -2.20 to $+0.32 \%$ ) and a highly negative $\delta^{18} \mathrm{OV}-\mathrm{PDB}(-4.95$ to $-2.88 \%$ ). Stromatolitic limestones (SLC8 facies) with significant sparry calcite cementation (class II samples) are significantly depleted in ${ }^{13} \mathrm{C}$ and ${ }^{18} \mathrm{O}$ compared to class I samples, with $\delta^{13} \mathrm{CV}$-PDB values ranging from -1.93 to $-2.77 \%$ and $\delta^{18}$ OV-PDB values ranging from -5.16 to $-6.29 \%$ (Table B). 


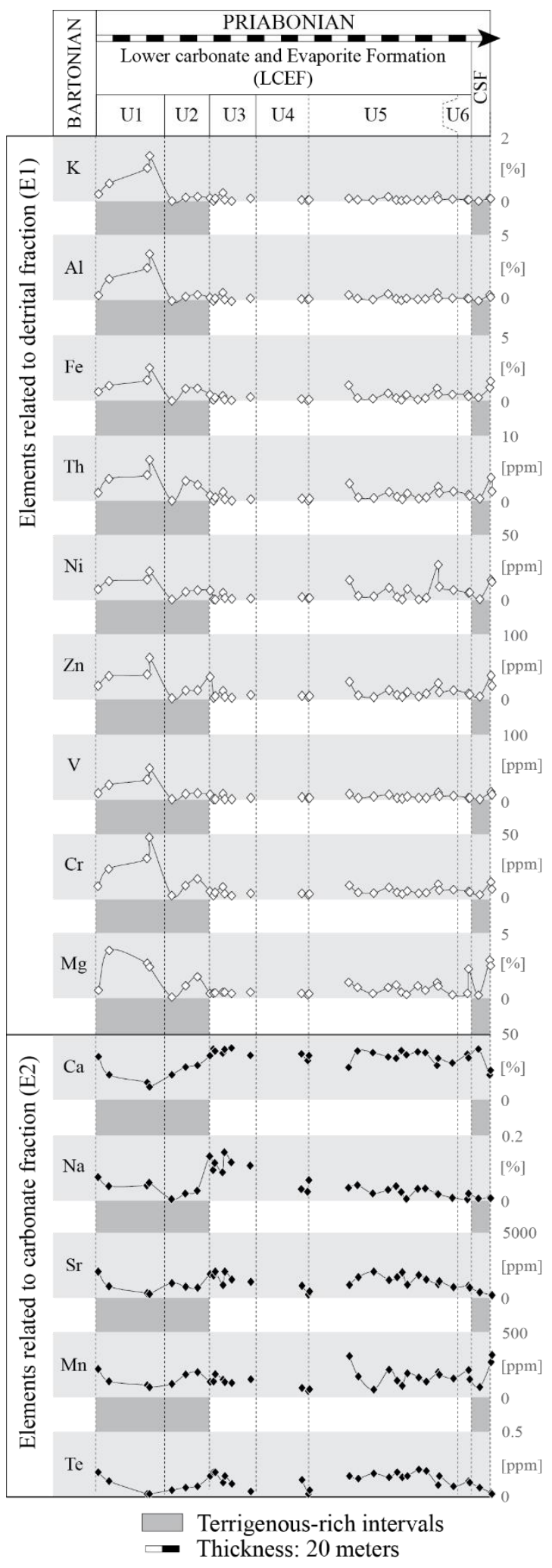

Fig. 11. Vertical distribution of the abundance of the main elements through the Priabonian section of the Saint-Chaptes Basin. Values were determined by ICP-MS analyses and expressed in part per million (ppm) or in percent (\%).
The carbon and oxygen isotope signature of the units U4 contrasts sharply with that of the other units (Fig. 10C). Measurements in unit U4 indicate a strong depletion in ${ }^{13} \mathrm{C}$ with $\delta^{13} \mathrm{CV}$-PDB values ranging from -2.67 to $-4.76 \%$ (Table B). The corresponding interval has the following characteristics: 1) carbonates contain significant proportion of calcitic microsparitic infilling partly or entirely the intergranular space of peloidal sands (diagenetic class IV); 2) mudstones are rich in dark, organic matterrich laminae; and 3) leached lense-shaped gypsum crystal are common. $\delta^{18} \mathrm{OV}-\mathrm{PDB}$ values of unit $U 4$ samples are negative and range from -3.34 to $-4.26 \%$ (Table $B$ ).

In the unit U5, the isotopic signature of carbonates is characterized by an apparent covariant trend between $\delta^{13} \mathrm{CV}-\mathrm{PDB}$ and $\delta^{18}$ OV-PDB (Fig. 10C). Class I samples (SLC2 molluscan-ostracodal mudstone and SLC5 papyraceous argillaceous mudstone) exhibit a relatively narrow range of positive $\delta^{13} \mathrm{CV}$-PDB (from +0.69 to $+1.80 \%$ ) whereas $\delta{ }^{18} \mathrm{OV}$-PDB is highly variable (from -6.53 to $-0.84 \%$ ). The most ${ }^{18} \mathrm{O}$ enriched values correspond to papyraceous argillaceous mudstone $\left(\delta^{18} \mathrm{OV}\right.$ PDB: -3.21 to $-0.84 \%$ ) whereas molluscanostracodal mudstone are mostly ${ }^{18} \mathrm{O}$ depleted ( $\delta^{18} \mathrm{OV}-\mathrm{PDB}:-5.84$ to $-2.23 \%$ ). Diagenetic class II samples from unit U5 mainly consist of peloidal grainstones (facies SLC6) whose intergranular pore space is entirely occluded by sparry calcite cement. Class II samples are ${ }^{13} \mathrm{C}$ and ${ }^{18} \mathrm{O}$ depleted compared to class I samples from the same unit $\left(\delta^{13} \mathrm{CV}\right.$-PDB: -0.19 to $+0.81 \% ; \delta^{18} \mathrm{OV}-\mathrm{PDB}:-6.53$ to $-3.51 \%$ ).

In the unit U6 (Fig. 10D), class I samples include molluscan-ostracodal mudstones (SLC2 facies) and silty marlstones (MTC3). In contrast to unit U5, class I samples exhibit negative $\delta^{13} \mathrm{CV}-\mathrm{PDB}$ values (from -0.32 to $0.61 \%$ ) and low variations in $\delta^{18} \mathrm{OV}-\mathrm{PDB}$ (from -3.12 to $-4.36 \%$ ). Samples with high content in sparry calcite cement (class II) are significantly depleted in ${ }^{18} \mathrm{O}\left(\delta^{18} \mathrm{OV}-\mathrm{PDB}\right.$ : -7.50 to $-3.61 \%$ ) whereas $\delta^{13} \mathrm{CV}-\mathrm{PDB}$ remain moderately negative (from -1.83 to $0.00 \%$ ). 


\subsubsection{Major, minor and trace elements}

As illustrated on Figure 11, a strong correlation exists with the vertical variations of the $\mathrm{K}, \mathrm{Al}, \mathrm{Fe}, \mathrm{Th}, \mathrm{Ni}, \mathrm{Zn}, \mathrm{V}, \mathrm{Cr}$ and $\mathrm{Mg}$ element concentrations. Maximum values are observed in the terrigenous-rich intervals (clay and/or quartz-rich deposits from units U1, $\mathrm{U} 2$ and $\mathrm{U6}$ ). Abundance of $\mathrm{Fe}, \mathrm{K}, \mathrm{Al}$ and $\mathrm{Mg}$ exhibits strong positive correlations with Pearson indices ranging from 0.704 to 0.994 (Fig. 12 and Table 2). In contrast, $\mathrm{Ca}$ negatively correlates (Fig. 12B and Table 2) with Fe, K, Al and $\mathrm{Mg}$ (Pearson indices: -0.785 to -0.920). Finally the abundance of $\mathrm{Na}$ is not significantly correlated with that of $\mathrm{Fe}, \mathrm{K}, \mathrm{Al}$ and $\mathrm{Mg}$ (Fig. 12D and Table 2).

Table 2. Pearson correlation coefficients between all pair of geochemical elements ( $\mathrm{Al}, \mathrm{Fe}, \mathrm{Mg}, \mathrm{Ca}, \mathrm{K}$ and $\mathrm{Na}$ ).

\begin{tabular}{lllllll}
\hline$N=28$ & $\mathrm{Al}$ & $\mathrm{Fe}$ & $\mathrm{Mg}$ & $\mathrm{Ca}$ & $\mathrm{K}$ & $\mathrm{Na}$ \\
\hline $\mathrm{Al}$ & 1 & 0.927 & 0.744 & -0.901 & 0.994 & 0.011 \\
$\mathrm{Fe}$ & 0.927 & 1 & 0.708 & -0.920 & 0.904 & -0.135 \\
$\mathrm{Mg}$ & 0.744 & 0.708 & 1 & -0.785 & 0.704 & -0.011 \\
$\mathrm{Ca}$ & -0.901 & -0.920 & -0.785 & 1 & -0.873 & 0.210 \\
$\mathrm{~K}$ & 0.994 & 0.904 & 0.704 & -0.873 & 1 & 0.034 \\
$\mathrm{Na}$ & -0.011 & -0.135 & -0.110 & 0.210 & 0.034 & 1 \\
\hline
\end{tabular}
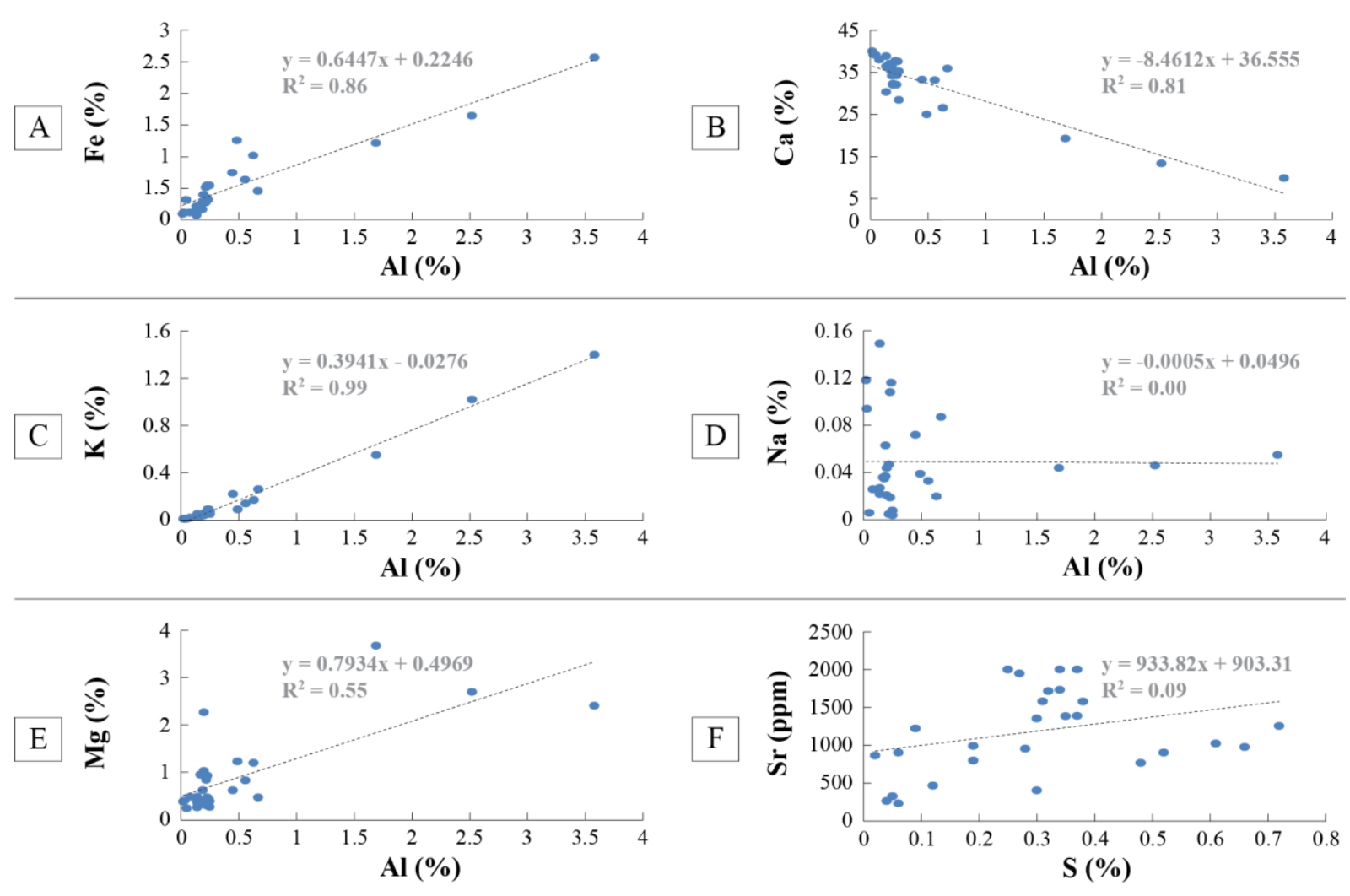

Fig. 12. Cross-plots of elemental concentrations after ICP-MS analyses: (A) Fe vs Al; (B) Ca vs $A l$, (C) K vs $A l$; (D) Na vs $A l$; (E) Mg vs Al; (F) Sr vs S. Equation of the linear regressions and related Pearson coefficient are mentioned for each crossplot. 
A

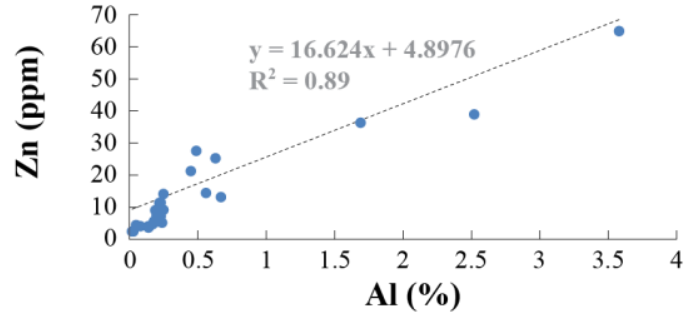

$\mathrm{C}$

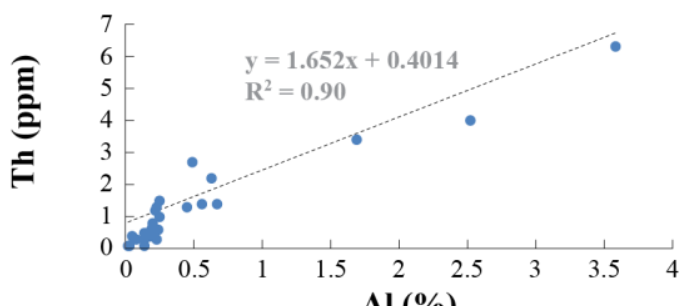

B

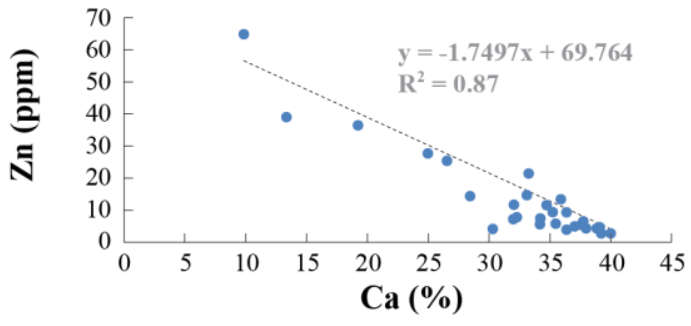

$\mathrm{D}$
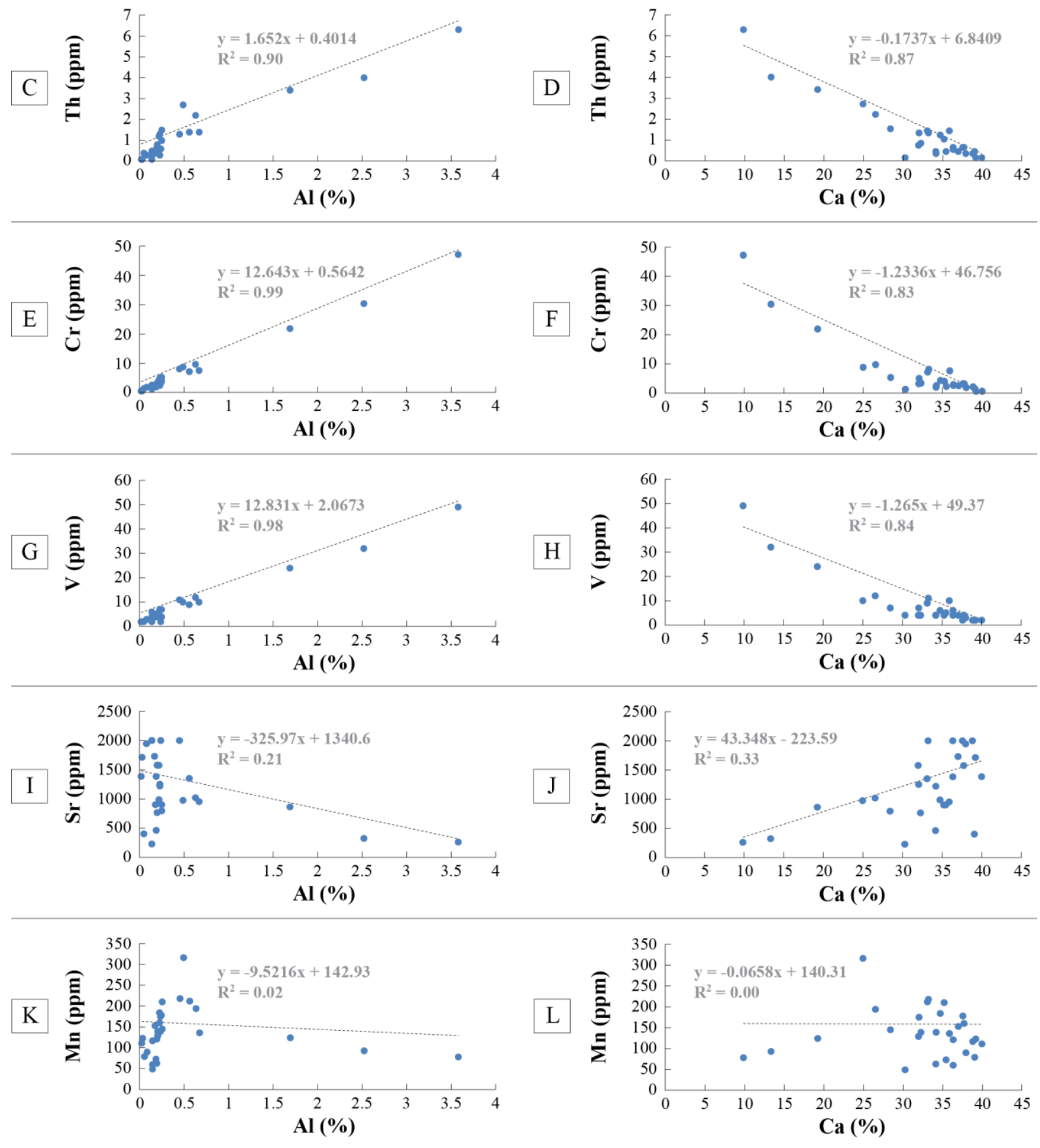

Fig. 13. Cross-plots of selected trace-element concentration as a function of $A l$ and $C a$ abundance respectively: $(A$ and $B))$ $\mathrm{Zn}$; (C and D) Th; (E and F) Cr; (G and H) V; (I and J) Sr; (K and L) Mn. 
As illustrated on Figure 13, the abundance of selected trace elements including Zn, $\mathrm{Th}, \mathrm{Cr}$, and $\mathrm{V}$ displays strong positive correlation with $\mathrm{Al}$ content (Pearson indices: from 0.942 to 0.995 ), and strong negative correlation with Ca content (Pearson indices: from 0.911 to -0.934$)$. In contrast, $\mathrm{Sr}$ and $\mathrm{Mn}$ do not show significant correlation with $\mathrm{Al}$ and $\mathrm{Ca}$ (Figs 13l, 13J, 13K and 13L). The strong negative correlation between $\mathrm{Al}$ and $\mathrm{Ca}$ and the low deviation from the linear regression (Fig. 12B) is indicative of a mixture between terrigenous material and carbonate formed into the lake. The low $\mathrm{Mg}$ content $(<3.68 \%)$ over the whole section confirms the absence or scarcity of dolomite in the Saint-Chaptes Priabonian carbonate deposits.

In addition, no preserved sulfate mineral has been identified either in the field or in thin-sections (only molds after gypsum crystal dissolution are present) and sulfur concentrations are always very low $(<0.72 \%)$. As a consequence the analyzed elements have been grouped into two main classes (Fig. 11) these are: 1) class E1containing terrigenous-related-elements ( $\mathrm{K}, \mathrm{Al}, \mathrm{Fe}, \mathrm{Th}, \mathrm{Ni}, \mathrm{Zn}, \mathrm{V}, \mathrm{Cr}$ and $\mathrm{Mg}$ ); and 2) class E2 containing carbonate-related elements ( $\mathrm{Ca}, \mathrm{Na}, \mathrm{Sr}$ and $\mathrm{Mn}$ ). As suggested by clay assemblage analyses $\mathrm{Al}, \mathrm{Fe}, \mathrm{Mg}$ and $\mathrm{K}$ are probably related to $\mathrm{I} / \mathrm{S} \mathrm{RO}$ and illite. The concentration of calcium is therefore considered as being related to the calcite content.

Since no positive correlation is evidenced between $\mathrm{Sr}$ and terrigenous element content (Fig. 11), the Sr may be related to: 1) an incorporation into calcite or aragonite (replacement of $\mathrm{Ca}$ ); 2) an incorporation into calcium sulfates (replacement of $\mathrm{Ca}$ ); and 3 ) the presence of celestine $\left(\mathrm{SrSO}_{4}\right)$. The general scarcity of preserved sulfur $(<0.72 \%)$ and the lack of significant correlation between Sr and S content (Fig. 12F), strongly suggest that strontium is mostly related to the carbonate fraction. Since aragonite (mollusc shells) is only preserved from few clay-rich intervals (in units $U 1$ and $\mathrm{U} 2$ ), the $\mathrm{Sr} / \mathrm{Ca}$ ratio calculated from trace element analyses from units U3 to U6 is therefore considered as representing the $\mathrm{Sr} / \mathrm{Ca}$ of calcite. $\mathrm{Sr} / \mathrm{Ca}$ in calcite depends on the water-contained $\mathrm{Sr} / \mathrm{Ca}$

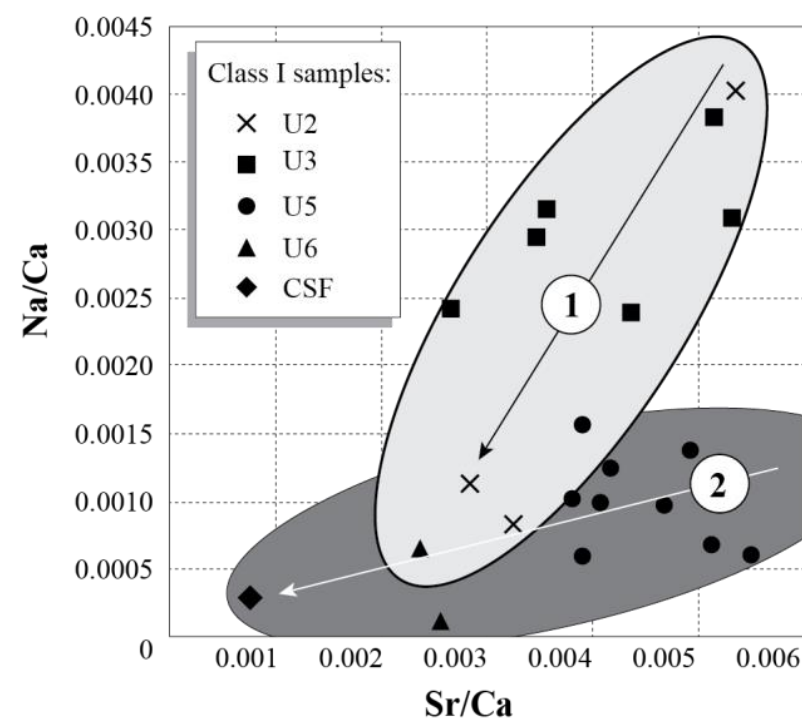

1: Increasing deconnection with regional water bodies (Units U5, U6 and CSF)

2: Dilution (fresh-water \& salt water mixture)

Fig. 14. $\mathrm{Na} / \mathrm{Ca}$ vs Sr/Ca cross-plot, for diagenetic class I samples. and on the distribution coefficient $K_{D}$. By considering the moderate range of temperature variations during the Priabonian (e.g. Bauer et al., 2016), the effect of temperature on the distribution coefficient is assumed to be minor throughout the studied time interval (Renard, 1975). High concentrations of sodium chloride, sulfate and magnesium in water may have a depressive effect on $K_{D}$ (Holland et al., 1963; Kinsman and Holland, 1969). Significant effects of sodium chloride is unlikely since the lower sodium contents correspond to the lower strontium contents (Fig. 14). In addition, the overall low magnesium content in the bulk rock, its correlation with terrigenous supplies and the lack (or extreme scarcity) of dolomite in the Priabonian succession of the SaintChaptes Basin, suggests that magnesium concentrations in water 
remained low to moderate and probably did not affect significantly the distribution coefficient of the Sr/Ca ratio. By contrast, although poorly preserved, sulfates were present at high concentrations in the Saint-Chaptes Basin, as indicated by the gypsum relics from units U4 and U6. As a consequence, potential control of sulfate concentration must be considered in the interpretation of measured $\mathrm{Sr} / \mathrm{Ca}$ from carbonate rocks in evaporitic intervals.

Sodium may be related to adsorption on calcite crystals, Na-bearing clays and $\mathrm{Na}$ bearing feldspars. In the Priabonian succession of the Saint-Chaptes Basin, XRD analyses revealed that, only interstratified smectite-illite (IS RO) may potentially represent a source of sodium in the clay fraction of the sediment and their proportion display low variations from unit U2 to unit U6 (70 to 94\%). Clays and feldspars are unlikely to represent a significant source for sodium in the studied samples from unit U2 to the CSF since: 1) no positive correlation is evidenced between sodium and terrigenous content in limestones and argillaceous/silty limestones (Fig. 11); and 2) $\mathrm{Na} / \mathrm{Ca}$ is significantly lower in the most terrigenous intervals (unit U2 and CSF) than in the unit U3 limestones (Fig. 12). However, although the influence of sodium from non-carbonate minerals is still possible in a few samples, it can be argued that a low $\mathrm{Na} / \mathrm{Ca}$ in a bulk carbonate rock indicates that carbonate minerals formed from a water containing little sodium or have been reequilibrated with a sodium-poor solution (Land and Hoops, 1973). In order to reduce the uncertainly related to a potential diagenetic alteration of the initial carbonate $\mathrm{Na} / \mathrm{Ca}$ and $\mathrm{Sr} / \mathrm{Ca}$ ratios, only values for diagenetic class I samples have been considered for lake chemistry reconstructions (Fig. 14).

\subsection{Diagenetic features}

The Priabonian limestones from the Saint-Chaptes Basin have undergone various phases of diagenetic transformations including: 1) selective dissolution of gypsum and aragonite (mollusc shells); 2) sparry calcite cementation; 3) microcrystalline cementation; and 4) pedogenesis.
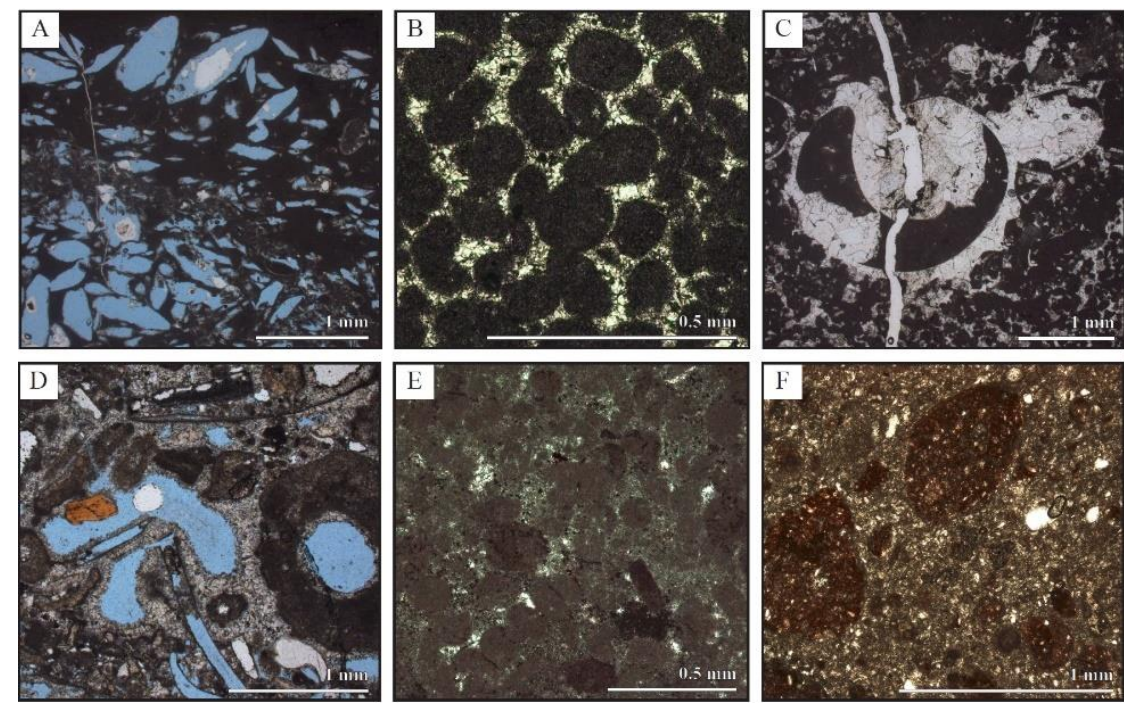

Fig. 15. Thin-section photomicrographs illustrating the main diagenetic features. (A) moldic pores after leaching of lenticular gypsum crystals within mudstone deposits (facies SLC3). (B) Mosaic to drusy blocky calcite cementation occluding the intergranular space of a well sorted peloidal grainstone (SLC6 facies). (C) Sparry calcite cement (C2) within a moldic pore resulting from the dissolution of an aragonitic gastropod shell. (D) Anisopachous fringes of bladed calcite cements (C1 cement) within an oncolitic grainstone. (E) Calcite microspar infilling the intergranular space of a peloidal grainstone. (F) Brecciated-nodular texture with clotted peloids interpreted as resulting from pedogenic processes.

Lettéron, A., Hamon, Y., Founier, F., Séranne, M., Pellenard, P. and Jospeh, P., 2018. Reconstrcutnion of a saline, lacustrine carbonate system (Priabonian, St-Chaptes Basin, SE France): depositional models, paleogeogrpahix and paleoclimatic implications. Sedimentary Geology, 367, 20-47. 


\subsubsection{Dissolution features}

Dissolution features are widespread in the whole section. Dissolution selectively affects gypsum crystals (Fig. 15A) disseminated in limestones (in units U4 and U6) and mollusc aragonite shells. By contrast, aragonitic shells are usually well preserved in clayrich intervals (e.g. in palustrine marlstones from unit U2). Calcitic bioclasts (benthic foraminifera, ostracods and characean gyrogonites) are generally well preserved except in pedogenic horizons.

\subsubsection{Sparry calcite cementation}

The formation of calcite spars occurs in the intergranular pore space of peloidal grainstones (SLC6 facies - Fig. 15B) and oncolitic-bioclastic grainstones-rudstones (SLC7 facies), in the fenestral pores of the stromatolitic limestones (facies SLC8) and within moldic and intraskeletal pores or fractures (Fig. 15C). The petrographic analyses of thinsections allowed to distinguish two types of sparry calcite cements:

- Anisopachous fringes of bladed calcite cements (C1 cement: Fig. 15D): they are found in units U2 and U3, infilling partially the intergranular pore space of oncolitic grainstones and fenestral pores of stromatolites. Samples with C1 cement (diagenetic class II) are significantly depleted in ${ }^{13} \mathrm{C}\left(\delta^{13} \mathrm{CV}\right.$-PDB: from 1.93 to -2.77$)$ and ${ }^{18} \mathrm{O}\left(\delta^{18} \mathrm{OV}-\mathrm{PDB}\right.$ : from -5.16 to -6.29$)$ compared to samples that are devoid of cement (diagenetic class I). The anisopachous nature of the cement fringes, their strongly ${ }^{13} \mathrm{C}$-depleted isotopic composition and the lack of mechanical compaction evidences in the corresponding samples suggest that C1 cements formed in meteoric vadose environments during early phases of subaerial exposures.

- Mosaic to drusy blocky calcite cements (C2 cement: Fig. 15B): they occurred essentially in units U5 and U6 where they generally occlude entirely the intergranular pores of grainstones, molds or fractures. Samples with C2 cements (diagenetic class II) are slightly depleted in ${ }^{13} \mathrm{C}$ and ${ }^{18} \mathrm{O}$ compared to samples devoid of cements (diagenetic class I) with $\delta^{13} \mathrm{CV}-\mathrm{PDB}$ values ranging from +0.81 to $-1.83 \%$ and $\delta^{18} \mathrm{OV}$-PDB values ranging from -3.51 to $-6.53 \%$. The carbon and oxygen isotope signature of cement C2 has not been directly measured (no micro-sampling performed), but the trends identified on $\delta^{13} \mathrm{CV}$ PDB- $\delta^{18} \mathrm{OV}-\mathrm{PDB}$ cross-plots (Fig. 10D) allow a range of $\delta^{13} \mathrm{C}$ and $\delta^{18} \mathrm{O}$ values to be estimated for this cement: moderately negative in $\delta^{13} \mathrm{CV}-\mathrm{PDB}$ (from 0 to $-2 \%$ ) and highly negative in $\delta^{18} \mathrm{OV}-\mathrm{PDB}(<-7 \%$ ). The overall morphology of the cements, their vertical distribution in the Priabonian succession and their estimated isotopic signature suggest a formation in a meteoric phreatic or freshwater lacustrine phreatic diagenetic domain, after the deposition of unit U6.

\subsubsection{Microcrystalline cementation}

Calcitic microsparite infills of the intergranular space of peloidal sands have been evidenced within unit U4 (Fig. 15E). The highly negative $\delta^{13} \mathrm{CV}$-PDB of the peloidal carbonates from unit U4 (from -2.67 to $-4.76 \%$ ) may result from a meteoric vadose origin of the intergranular microsparite (neomorphosed micrite matrix or microsparitic cement). However, their close association with leached gypsum crystals and the lack of subaerial 
exposure features identified in unit U4 may also suggest carbonate precipitation resulting from bacterial sulfate reduction processes (e.g. Visscher et al., 2000).

\subsubsection{Pedogenic features}

Pedogenic features are relatively rare in the Saint-Chaptes Basin. They have been identified at the base of unit U1, within unit $U 2$ and in unit U6. The main pedogenic features that have been identified are: 1) root traces (voids); 2) sideritic rhizoconcretions (Fig. 7H); 3) brecciated-nodular texture (Fig. 10F); 4) clotted-peloidal texture; and 5) dissolution of calcitic bioclasts. Samples with brecciated nodular and clotted-peloidal textures (diagenetic class III) have significantly ${ }^{13} \mathrm{C}$-depleted carbon isotopic signature with $\delta^{13} \mathrm{CV}$-PDB values ranging from -4.94 to $-5.35 \%$.

\section{Discussion}

\subsection{Evolution of lake chemistry, hydrology and depositional facies in response to paleoclimatic and paleogeographic changes}

The evolution of the Saint-Chaptes paleoclimate and paleoenvironment (water chemistry and hydrology) during the lower to mid-Priabonian has been reconstructed from the integration of biological assemblages (molluscs, foraminifera, ostracods), palynological data, sedimentological and mineralogical features, trace element measurements and stable isotope of carbon and oxygen.

\subsubsection{Unit U1}

The molluscan assemblage from the basal limestone of unit U1 (Galba, Strophostoma, Glandina, Cyclostoma) is strongly indicative of fresh-water environments. The basal limestone (Euzet vertebrate fossil site, Fig. 6) is a pedogenic carbonate breccia (facies P1) suggesting palustrine environments at the onset of the Priabonian lacustrine carbonate system development in the Saint-Chaptes Basin. The overlying monotonous succession of silty marls (facies MTC1) suggests a deposition in a perennial lake, dominated by terrigenous sedimentation. The negative $\delta{ }^{13} \mathrm{CV}$-PDB signature of the lacustrine marls (from -1.58 to $-2.65 \%$ ) is consistent with a continental origin of the carbonate fraction and may be related to the recycling of organic carbon deriving from the marginal swamps. The strong variations in $\delta{ }^{18} \mathrm{OV}-\mathrm{PDB}(-4.09$ to $+0.82 \%)$ coupled with almost unchanged $\mathrm{Q}^{13} \mathrm{CV}$-PDB are indicative of evaporitic conditions. Evaporitic conditions are also supported by the presence of palygorskyte within the silty marls (e.g. Singer, 1984; Verrecchia and Le Coustumer, 1996; Colson et al., 1998). The high Sr/Ca ratio measured in the basal limestones (Fig. 6) are probably linked to the reworking of Mesozoic limestone elements contained in the overlying Bartonian conglomerates. $\mathrm{Sr} / \mathrm{Ca}$ values in the overlying silty marls are low $(<0.003)$ and are consistent with a lake water of continental origin (e.g. Renard, 1975; Chivas et al., 1993). In contrast anomalously high $\mathrm{Na} / \mathrm{Ca}$ ratio may be related to the presence of $\mathrm{Na}$-bearing minerals (feldspars?) in the terrigenous fraction.

As a consequence, limestones and silty marls from unit U1 record a deposition in a fresh-water lake with a negative inflow-evaporation balance, probably in a relatively dry climatic setting. 


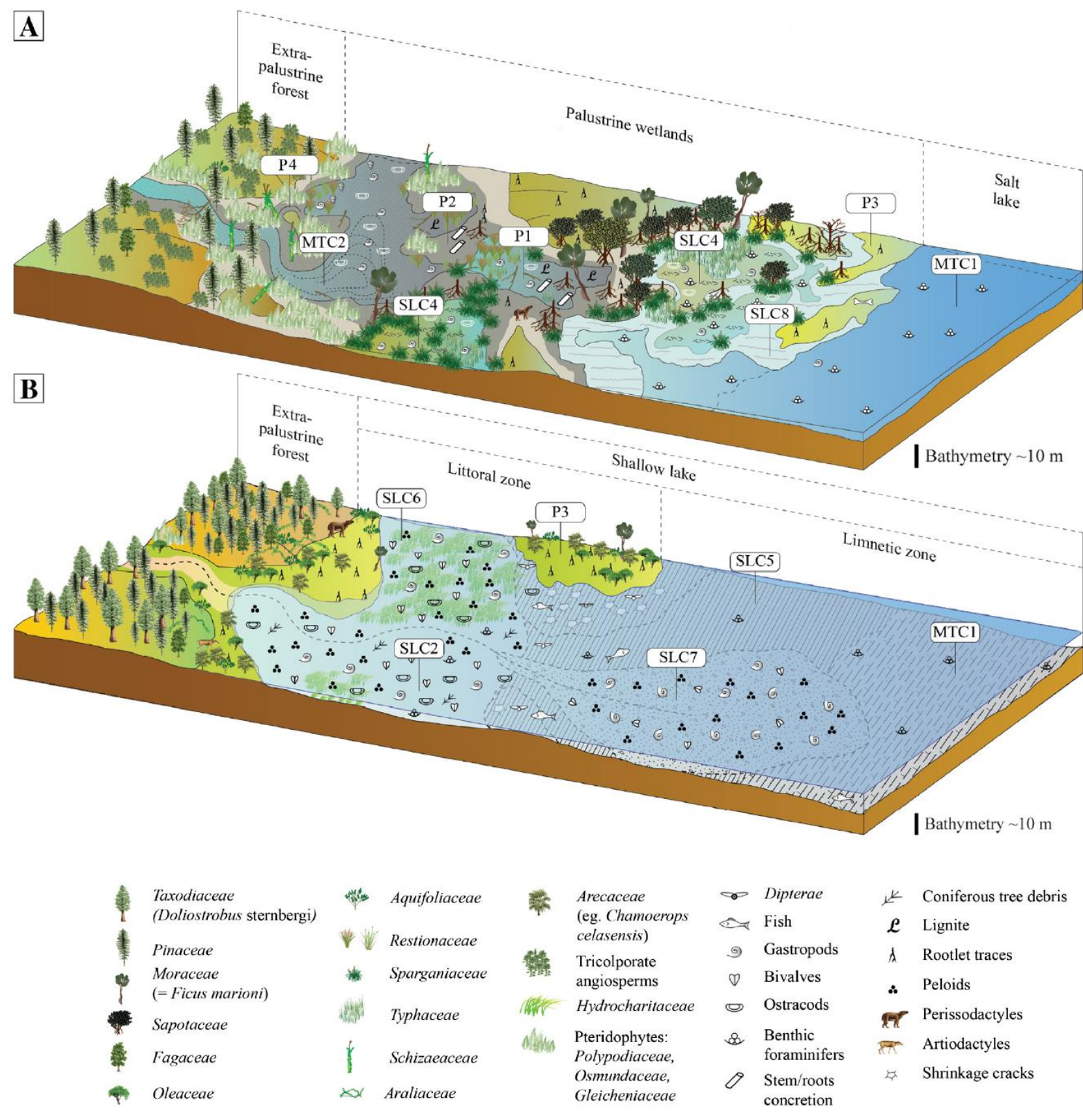

Fig. 16. Depositional models for Priabonian salt lake carbonate systems from the Saint-Chaptes Basin. (A) Salt-lake and wetland model under wet-climate (U2 and U3 units). (B) Salt lake model under dryer climate (U5 and U6 units).

\subsubsection{Unit U2}

Unit U2 deposits, dominated by MTC3 facies, reflect the development of a mixed carbonate-siliciclastic system with high content in sand-sized quartz particles which suggests significant surface water inflows within the lake. This is consistent with the palynological assemblage (FLA1) that suggests subtropical to tropical humid climate and major development of the lacustrine swamp area (Fig. 16A). The occurrence of palustrine lignite beds at the top of unit U2 also provides evidence of humid climatic conditions. In addition, the low variations in $\delta^{18} \mathrm{OV}$-PDB suggest low evaporation compared to inflow, which is also consistent with a relatively humid climate. Such low evaporation and tropical humid conditions are in agreement with the dominance of I/S RO (close to true smectite) the occurrence of small content of kaolinite and the disappearance of palygorskite in the clay assemblage. In the context of an open lake system under a humid climate, the 
dominantly positive $\delta^{13} \mathrm{CV}$-PDB values could be related to: 1) a significant ${ }^{13} \mathrm{C}$ uptake related to photosynthetic activity in the lake that controls the carbon isotopic composition of the dissolved inorganic carbon (DIC); or 2) a connection of the lake with a neighboring sea-water-influenced water body (Fig. 16A). The latter interpretation would be supported by the occurrence of benthic foraminifera in the upper part of unit U2 that suggests brackish water conditions. In addition, the $\mathrm{Sr} / \mathrm{Ca}$ and $\mathrm{Na} / \mathrm{Ca}$ ratios exhibit strong variations with the maximum values of 0.0053 and 0.0040 respectively (Fig. 14). Such values match within the range of $\mathrm{Sr} / \mathrm{Ca}$ and $\mathrm{Na} / \mathrm{Ca}$ of the estuarine/lagoonal Bartonian Saint-Ouen Limestone from the Paris Basin (Renard, 1975). However, since elevated Sr contents are present in most marine evaporites (e.g. Playà and Rosell, 2005), the leaching of gypsum, anhydrite and halite and the accumulation of the produced ions in lakes may also result in high $\mathrm{Sr} / \mathrm{Ca}$ and $\mathrm{Na} / \mathrm{Ca}$ ratio in lacustrine carbonates.

As a consequence, mixed carbonate-siliciclastic deposits from unit $\mathrm{U} 2$ record a lacustrine to palustrine sedimentation in a palustrine wetland environment such as lacustrine swamp close to a salt lake and under a tropical to subtropical humid climate (Figs 16A and 6). The salinity revealed by the present data may result from: 1) a connection with marine environments or with neighboring marine-influenced lake waters; 2) a connection with a neighboring inland salt lake; and 3) a direct supply in salts derived from the leaching of marine evaporites though groundwater or surface water inflows.

\subsubsection{Unit U3}

Unit U3 is characterized by a dominant shallow-water, lake margin (saltmarsh), carbonate sedimentation (SLC4 and SLC8 facies). The molluscan assemblage is dominated by the brackish water gastropod Potamides. Brackish water conditions are further supported by the common occurrence of small benthic foraminifera (Fig. 16A). The humid character of the climate prevailing during unit U3 deposition is supported by the FLA1 floral assemblage. The $\delta^{18} \mathrm{OV}$-PDB values are negative and dos not show strong variations thus suggesting non-evaporative conditions consistent with the prevailing humid climate. The depletion in ${ }^{13} \mathrm{C}$ of unit U3 limestones compared to unit U2 is likely to be related to the abundance of calcite rafts that are known to develop in carbonate-rich stagnant water bodies where degassing of carbon dioxide occurs (Folk et al., 1985; Gandin and Capezzuoli, 2014). In addition, as for the top of unit U2, limestones display elevated $\mathrm{Sr} / \mathrm{Ca}$ and $\mathrm{Na} / \mathrm{Ca}$ ratios (up to 0.0053 and 0.0038 respectively) consistent with a formation within a lake influenced by seawater (Renard, 1975) or by recycled evaporites.

As a consequence, unit U3 limestones have been deposited within a salt lake system, in a tropical to subtropical humid climate (Figs 16A and 6).

\subsubsection{Unit U4}

Unit U4 is characterized by an alternation of marls and carbonate mudstones with figures of gypsum crystal dissolution (SLC3 facies), suggesting evaporitic conditions. The palynological assemblage found in unit U4 suggests drier substrate conditions around the lake and could be related to a subtropical to mediterranean climate characterized by a dry season?also supported by the high proportion of I/S RO (likely original Fe-Al smectite formed during pedogenesis). Evaporites may, therefore, have formed during dry seasons in a very shallow, closed salt lake. The highly negative $\delta^{13} \mathrm{CV}$-PDB of these carbonates may result from an early diagenetic phase of ${ }^{13} \mathrm{C}$-depleted microsparitic cement formation that may be related to bacterial sulfate reduction processes. The very low Sr/Ca ratios of unit 
U4 (Fig. 6) carbonates may be related: 1) to the depressive effect of high sulfate concentrations on the Sr incorporation into calcite crystals; or 2) to the sequestration of the strontium available in the lake water as a result of evaporite precipitation, in the SaintChaptes Basin but possibly also in neighboring basins (Alès, Camargue or Mormoiron basins).

The deposition of unit U4 thus reflects a significant climate change characterized by drier conditions compared to unit U2 and U5 and to a higher degree of lake closure with regards to groundwater and surface water inflows and to neighboring salt lake systems.

\subsubsection{Unit U5}

Carbonate-dominated deposits from unit U5 (SLC1, SLC2, SLC5 and SLC6 facies) characterize perennial salt lake environments. Brackish water conditions are suggested by (Fig. 6): 1) the molluscan assemblage (Potamides and Polymesoda), 2) the common and regular occurrence of benthic foraminifera, 3) the presence of dinoflagellate cysts and 4) the high Sr/Ca ratios (>0.003). The palynological assemblage is similar to that of unit U4 and suggests subtropical to mediterranean climate with a dry season. Such a climatic setting is consistent with repeated desiccation cracks evidenced in marginal lake deposits (papyraceous argillaceous mudstone: SLC5 facies) that may represent seasonal drying of lacustrine mudflats (Fig. 16B) and the dominance of I/S R0 close to smectite. The existence of dry seasons with negative inflow-evaporation balance may explain the high variability of $\delta^{18} \mathrm{OV}-\mathrm{PDB}$ (from -5.84 to $-0.84 \%$ ) coupled with almost unchanging $\delta^{13} \mathrm{CV}-\mathrm{PDB}$ (from +0.69 to $+1.80 \%$ ) in lacustrine mudstones (Talbot, 1990; Arenas et al., 1997). Such positive $\delta^{13} \mathrm{CV}$-PDB values are a common feature of closed lakes with long water residence time (Talbot, 1990; Talbot and Kelts, 1990). They may also suggest that the DIC (dissolved inorganic carbon) from the influx waters are not significantly depleted in ${ }^{13} \mathrm{C}$ (e.g. Andrews et al., 1997), which could reflect a relatively dry, weakly-vegetated catchment area (Talbot, 1990). In addition, the regional basement of the Priabonian deposits are dominantly made of marine Cretaceous limestones that typically display positive $\delta^{13}$ CV-PDB values (e.g. Bastide, 2014). The leaching of the Cretaceous limestones in the catchment area may have resulted in ${ }^{13} \mathrm{C}$-enriched $\mathrm{HCO}_{3}{ }^{-}$waters. Positive $\delta^{13} \mathrm{CV}$-PDB values in carbonates would be also consistent with a formation in a marine-influenced water.

Finally, the absence of evaporite deposits in unit U5 is indicative of a lower degree of lake closure compared to the evaporitic unit U4, thus suggesting higher groundwater /surface water inflows or higher connectivity with neighboring lakes. The very low $\mathrm{Na} / \mathrm{Ca}$ values recorded in the unit U5 carbonates $(<0.002)$, combined with relatively high $\mathrm{Sr} / \mathrm{Ca}$ ratios ( $>0.003$ ) discard a purely marine origin for the salinity in the lake system. As a consequence, unit U5 carbonates deposited in a brackish water shallow perennial lake, probably connected to neighboring closed salt lakes that are disconnected from sea-water influences, in a subtropical to mediterranean climate with dry season.

\subsubsection{Unit U6 and Célas Sandstone Formation (CSF)}

The carbonate-dominated deposits from unit U6 (dominantly MTC2, SLC6 and SLC7 facies) are indicative of perennial salt lakes as evidenced by the occurrence of benthic foraminifera and brackish-water mollusc assemblages (Polymesoda). As for units U4 and U5, subtropical to mediterranean climate (Fig. 6) with dry season prevailed at the time of unit U6 andCélas sandstone deposition, as evidenced by the FLA2 floral assemblage. The shift toward negative $\delta^{13} \mathrm{CV}$-PDB values evidenced for unit U6 mudstones 


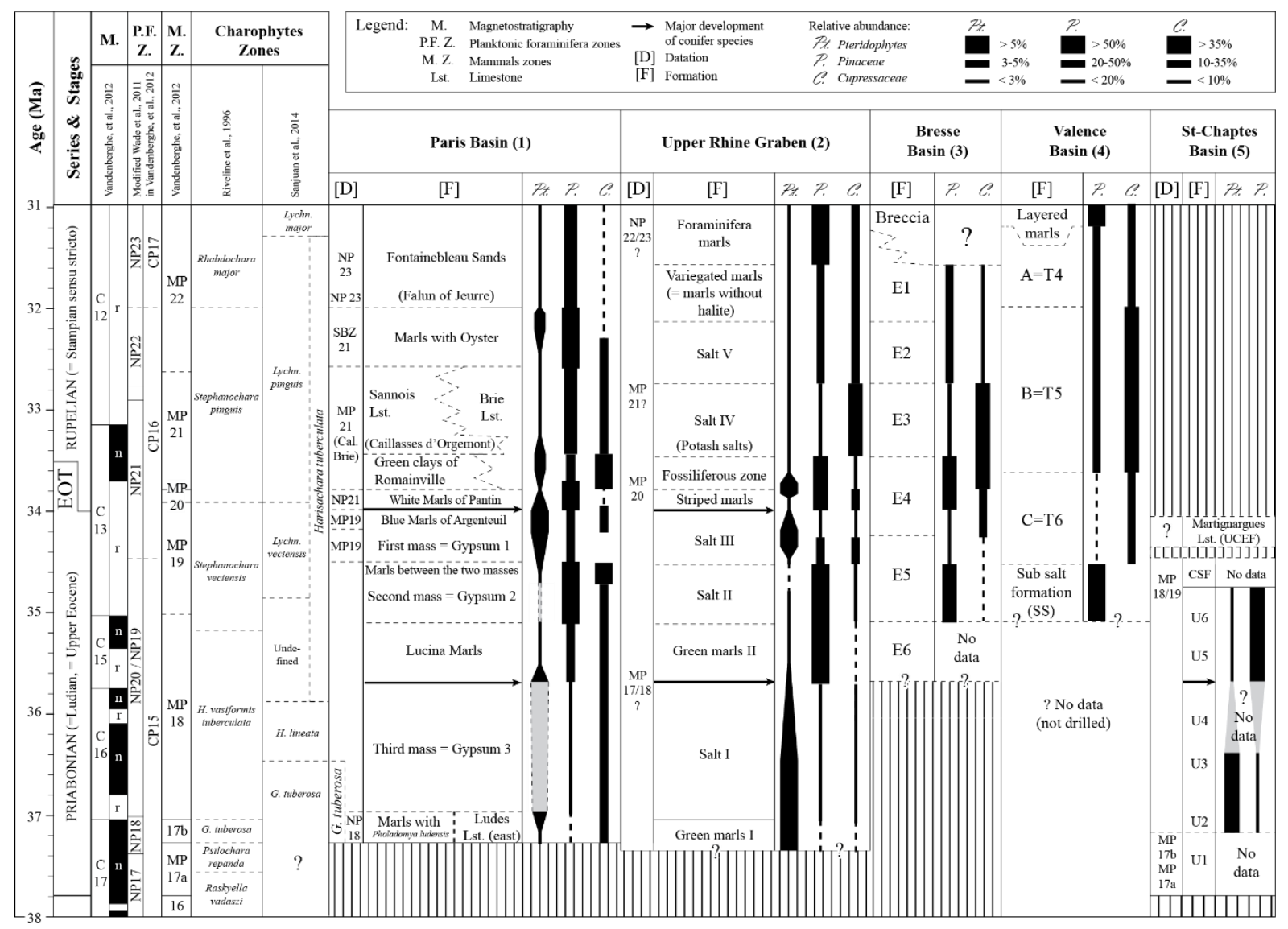

Fig. 17. Stratigraphic correlation chart for the Paris (1), Upper Rhine (2), Bresse (3), Valence and Saint-Chaptes (5) basins and the vertical evolution of the relative abundances of Pinaceae, Cupressaceae and Pteridophytes. The biostratigraphic (mammals and planktonic foraminifera zones) and magnetostratigraphic framework derives from Vandenberghe et al. (2012). The Charophyte zonations of Riveline et al. (1996) and Sanjuan et al. (2014) have been integrated. The chronostratigraphic framework of: - (1) the Paris Basin is compiled from Cavelier (1965); Châteauneuf and GruasCavagnetto (1978); Châteauneuf (1980); Aubry (1986); Gély and Lorenz, (1991); Rouchy and Blanc-Valleron (2009); and Briais (2015); - (2) the Upper Rhine Graben from Sittler et al. (1975); Duringer (1988); Schuler (1990); Blanc-Valleron (1991); Fontes et al., (1991); Blanc-Valleron and Schuler (1997); Becker (2003); Sissingh (2003); Giamboni et al. (2004); Berger et al. (2005A; 2005B); Roussé (2006); and Hinsken et al. (2007); - (3) Bresse Basin from Curial and Moretto (1997); - (4) Valence Basin from Gudefin (1977); Dumas (1987); Fontes et al. (1996); Dromart and Dumas (1997); - (5) St-Chaptes Basin from Feist-Castel (1971); Alabouvette et al. (1983); Frédet (1987); Remy (1994; 1999); Remy and Lesage (2005) and this study. Palynological data are compiled from Châtauneuf (1980) for the Paris Basin, Schuler (1990) for the Bresse and Valence basins and from Gruas-Cavagnetto (1973); Ellenberger (1980) and Alabouvette et al. (1983) for the Saint-Chaptes Basin. Additional abbreviations: C - polarity chron, CSF - Célas Sandstone Formation, EOT - Eocene-Oligocene Transition, Lst. limestone, MP - Paleogene mammalian reference level, $n$ - normal polarity, NP - standard calcareous nannoplankton, $r$ reverse polarity, SBZ - shallow benthic zone.

may be related to a disconnection from the regional closed salt lakes. The lake was therefore probably only fed with local surface and groundwater inflows. A severe disconnection from the local fresh-water inflows and from the regional lakes led to hypersaline conditions and gypsum precipitation at top of unit U6. This event (of possible tectonic origin?) foreshadows profound changes in the regional hydrological network, which subsequently led to the installation of a terrigenous deltaic system in the SaintChaptes Basin (Célas Sandstone Formation). The overall decrease in $\mathrm{Sr} / \mathrm{Ca}$ and $\mathrm{Na} / \mathrm{Ca}$ ratio from unit U5 to the Célas Sandstone Formation (Fig. 14) is consistent with a transitional disconnection of the ASCl lake with regional salt lakes and with a change in the dominant origin of water inflows (from salt water to fresh-water).

Lettéron, A., Hamon, Y., Founier, F., Séranne, M., Pellenard, P. and Jospeh, P., 2018. Reconstrcutnion of a saline, lacustrine carbonate system (Priabonian, St-Chaptes Basin, SE France): depositional models, paleogeogrpahix and paleoclimatic implications. Sedimentary Geology, 367, 20-47. 
The negative isotopic signature of both $\delta^{13} \mathrm{CV}$-PDB and $\delta^{18} \mathrm{OV}$-PDB of the carbonate fraction of the Célas Sandstone Formation (peloids and oncoids) and the very low $\mathrm{Sr} / \mathrm{Ca}$ and $\mathrm{Na} / \mathrm{Ca}$ ratios are consistent with a lake water of continental, freshwater origin. However, the occurrence of limestone beds with Polymesoda, interbedded within the sandstones (Depéret 1917; Remy, 1985) suggests that a residual salinity remained in the lake during the deposition of the Célas sandstones. In addition, the development of a deltaic siliciclastic system (Célas Sandstone Formation: CSF) from U6 carbonates to CSF terrigenous deposits may suggest a return to positive inflow-evaportation balance.

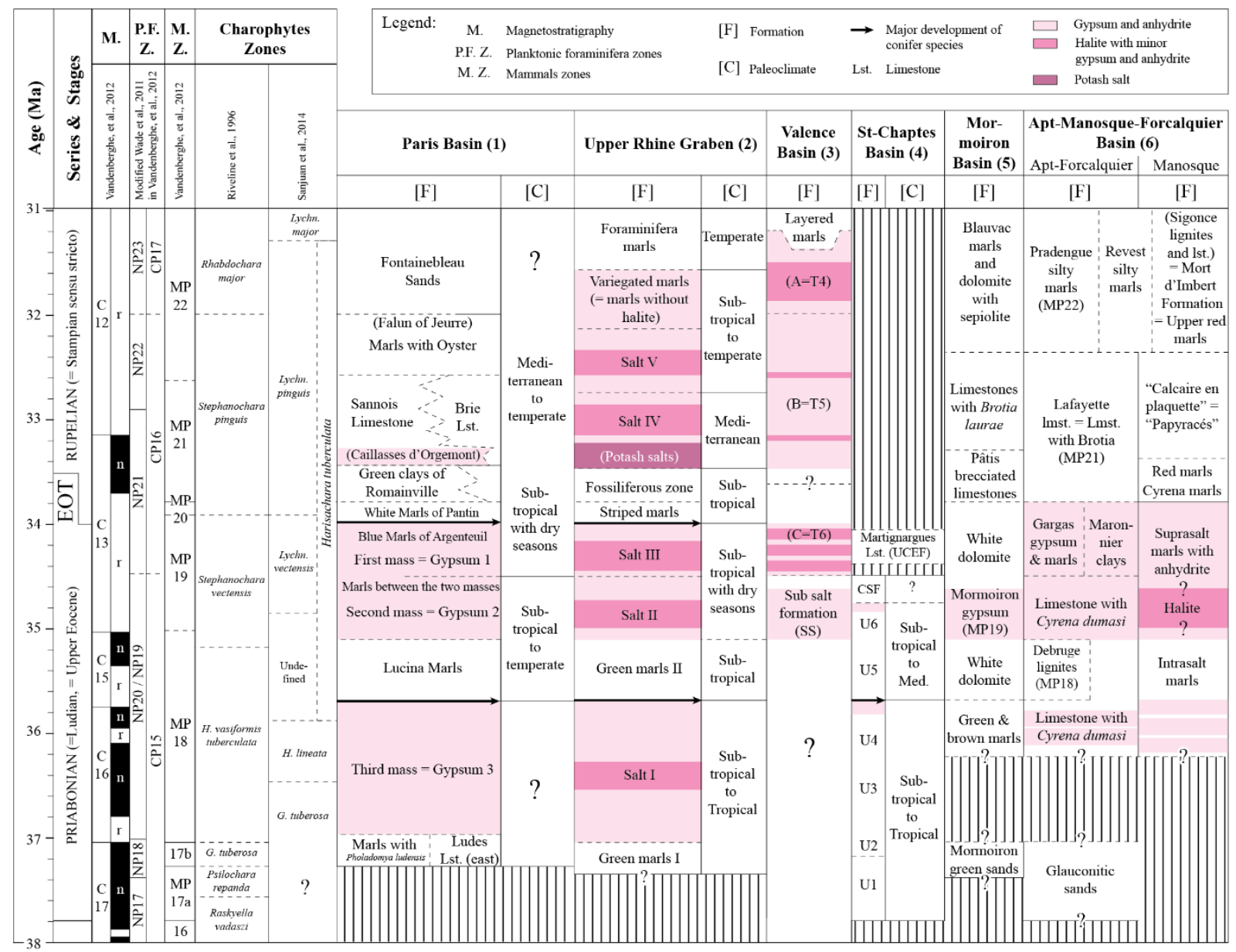

Fig. 18. Stratigraphic correlation chart synthetizing the stratigraphic distribution of saline Priabonian-Rupelian formations and paleoclimatic evolution of the Paris Basin (1), Upper Rhine Graben (2), Valence Basin (3), Saint-Chaptes Basin (4), Mormoiron Basin (5) and the Apt-Manosque-Forcalquier Basin (6). The chronotratigraphic framework of: (1) the Paris Basin has been compiled from Cavelier (1965); Châteauneuf (1980); Châteauneuf and Gruas-Cavagnetto (1978); Aubry (1986); Gély and Lorenz (1991); Rouchy and Blanc-Valleron (2009); and Briais (2015); - (2) the Upper Rhine Graben from Sittler et al. (1975); Duringer (1988); Schuler (1990); Blanc-Valleron (1991); Fontes et al. (1991); Blanc-Valleron and Schuler (1997); Becker (2003); Giamboni et al. (2004); Berger et al. (2005A; 2005B); Roussé (2006); and Hinsken et al. (2007); - (3) Valence Basin from Gudefin (1977); Dumas (1987); Fontes et al. (1996); Dromart and Dumas (1997); - (4) Saint-Chaptes Basin from Feist-Castel (1971); Alabouvette et al. (1983); Frédet (1987); Remy (1994; 1999); Remy and Lesage (2005) and this study; - (5) Mormoiron Basin and (6) Apt-Manosque-Forcalquier Basin from Destombes (1962); Gigot et al. (1975); Ducreux (1987); Lesueur (1991); Escarguel et al. (1997); Apostolescu and Dellenbach (1999); and Costeur et al. (2009; 2011). Additional abbreviations: C - polarity chron, CSF - Célas Sandstone Formation, EOT - Eocene-Oligocene Transition, Lst. - limestone, MP - Paleogene mammalian reference level, n- normal polarity, NP - standard calcareous nannoplankton, $r$ - reverse polarity. 


\subsection{The depositional record of Lower-Middle Priabonian climate changes in the St- Chaptes Basin}

Palynological synthesis reveals a major turnover in the floral assemblages during the deposition of the Lower to Middle Priabonian (MP17A-MP18) succession from the Saint-Chaptes Basin. Vegetation of the Saint-Chaptes Basin was dominated by pteridophytes and tropical species during U2 and U3 deposition, whereas their abundance decreased in favor of Pinaceae and Cupressaceae during U5 to U6 deposition. A similar floral change has been also recorded in the same time interval, from the "Green Lymnaea Marls II" formation in the Upper Rhine Graben (Schuler, 1990) and from the "Lucina Marls" formation in the Paris Basin (Châteauneuf, 1980) (Fig. 17). As a result, floral turnover from subtropical to tropical species to subtropical-mediterranean species detailed in the Saint-Chaptes Basin is not a local trend but likely reflects paleoclimate changes recorded at continental scale during the Lower-Middle Priabonian (Fig. 18). Palynological syntheses at European scale interpreted such a turnover as being part of a trend of climate aridification that occurred during the Priabonian (Schuler, 1990; PostigoMijarra et al., 2009) (Figs 17 and 18). The Saint-Chaptes clay mineralogy (occurrence of palygorskite) and stable isotope record evidence an early dry phase that occurred during the deposition of the lowermost Priabonian U1 unit (MP17A mammal zone), prior to the units U2-U3 humid stage, thus suggesting that late Eocene climate aridification started very early in Priabonian times and possibly earlier.

The humid to drier transition recorded by palynological data between unit U3 and unit U5 also largely controlled the sedimentological expression and the nature of the saline, carbonate lacustrine systems. The depositional facies associations identified from unit U2 to U6 (Fig. 4 and Table 2), allowed two distinct depositional models to be defined: 1) a humid climate mixed terrigenous-carbonate, salt lake model (units U2 and U3: Fig. 16A); and 2) a dryer climate carbonate salt lake model (units U5 and U6: Fig. 16B). The humid period depositional model (Fig. 16A) is characterized by the development of wetland environments at the transition between terrestrial and lacustrine domain, with significant deposition of palustrine facies including coal beds (facies P1). Lacustrine marginal deposits consist of massive, decimeter thick beds of calcite raft-bearing limestones (SLC4 facies) and stromatolites (SLC8 facies) with only scattered subaerial exposure surfaces.

In contrast, during periods of dryer climates (Fig. 16B), lake margins are characterized by the deposition of thinly laminated carbonates associated with the repeated occurrence of desiccation cracks (SLC5 facies), thus suggesting a seasonallycontrolled deposition. An increase in intra-annual seasonality throughout the Priabonian has been highlighted in the Isles of Wight, UK, (Gale et al., 2006; Sheldon et al., 2009), in the Paris Basin (Châteauneuf, 1980), and in the Rennes Basin, France (Ollivier-Pierre, 1980; Bauer et al., 2016, Tramoy et al., 2016). In addition, the occurrence of gypsum (in units U4 and U6) suggests occasional but significant negative inflow-evaporation balance in the lake system that is consistent with a relatively dry climate or at least with a seasonally dry climate.

Finally, the carbon and oxygen isotope record reveals open lake conditions for unit U3 carbonate system, whereas the lake behaves mostly like a closed lake during units U4 to U6 deposition. Such a change in lake closure degree is consistent with a decrease in water inflows in the basin and is likely to be related to the climate aridification trend evidenced by palynological data. 


\subsection{Priabonian saline lake environments in the St-Chaptes Basin: paleogeographic implications}

The origin of saline lake environments and associated evaporite deposits in Paleogene basins of western Europe is the object of various scientific debates and controversies (e.g. Bodergat et al., 1999). Salinization of lakes may result from various environmental and geological processes: 1) leaching of non-evaporitic rocks in the catchment area and their subsequent concentration in the lake as a result of negative inflow-evaporation balance (e.g. Spencer et al., 1985); 2) dissolution in surface of evaporite bodies such as exhumed salt diapirs (Emre and Truc, 1978) and accumulation of salts in a lake basin; and 3) connections with sea-water through topographic corridor or groundwater inflows in coastal area (Rouchy, 1997) (Fig. 19A); 4) accumulation of marine aerosols over an exposed continent in arid climates (e.g. Chivas et al., 1991; Herczeg et al., 2001); and 5) salt supply from hydrothermal fluid inflows (e.g. Vengosh et al., 1995; Chaboureau et al., 2012). In the Saint-Chaptes Basin, the oldest occurrence of significantly saline (oligo-mesohaline) lake environments is recorded within units U2 and U3 during periods of relatively wet climate as suggested by palynological and mineralogical assemblages and stable isotope results (Fig. 6). As a consequence the salinity is unlikely to be related to accumulation of ions deriving from the leaching of non-evaporitic rocks in the drainage area or from marine aerosols since such processes are restricted to dry climates. Triassic evaporites have been considered as a possible source for lake salinity in Priabonian and Rupelian rift basins from SE France (e.g. Truc, 1978; Fontes et al., 1996). Extensive Triassic gypsum/anhydrite and halite deposits are present in most of western Europe regions and most of the Paleogene rift basins developed above thick (up to 900 m) Triassic evaporites (Fig. 18). Subaerial dissolution of exhumed salt diapirs basins has been shown to have supplied significant amounts of salts in rhodanian lake basins during the Priabonian and Rupelian (Emre and Truc, 1978). In addition, a Triassic origin for salts has been evidenced for evaporites in upper Eocene playa-lake systems from the Almazán basin in Spain (Huerta et al., 2010). Below the Alès and Saint-Chaptes basins, east of the Cévennes fault system, Triassic evaporites are buried below a thick Mesozoic and Paleogene cover (Sanchis and Seranne, 2000). At a larger scale, except at the location of the salt diapirs (see location on Fig. 19B), Triassic evaporites are everywhere covered by a thick pre-Priabonian (Jurassic, Cretaceous and Paleocene-Eocene) sedimentary cover in the onshore domain comprised between the Cévennes and Durance fault systems. In addition, west of the Cévennes fault system, in the Cévennes and Montagne Noire massifs (see location in Fig. 19B), the Triassic succession is dominantly composed of terrigenous deposits and comprises only localized and thin evaporite-bearing intervals (Alabouvette et al., 1982; Cula and Courel, 1987). Therefore, surface paleo-water inflows coming from this area could nothave yielded sulfates in the ASCl lake. As a consequence leaching of Triassic evaporites from the Cévennes and Montagne Noire massifs probably did not contribute significantly to sulfate supplies in the Saint-Chaptes Basin during the Priabonian.

However, Keuper evaporites (mostly gypsum) crop out south-west of the $\mathrm{ASCl}$, in the Corbières (Lespinasse et al., 1982, Berger et al., 1997; Ellenberger et al., 1997). They are exposed in diapirs and in decollement associated with thrust planes, which are related to the Pyrenean orogenic structures (e.g. Gorini et al. 1991; Viallard and Gorini, 1994; Guennoc et al., 2000). Structural studies further west, along strike of the Pyrenean orogen clearly show the structural setting and the chronology of the evaporites rising across the Mesozoic cover up to aerial exposure during Pyrenean inversion (e.g. James and Canerot, 1999; Rougier et al., 2016). East of the Corbières, similar structures are present, deeply 


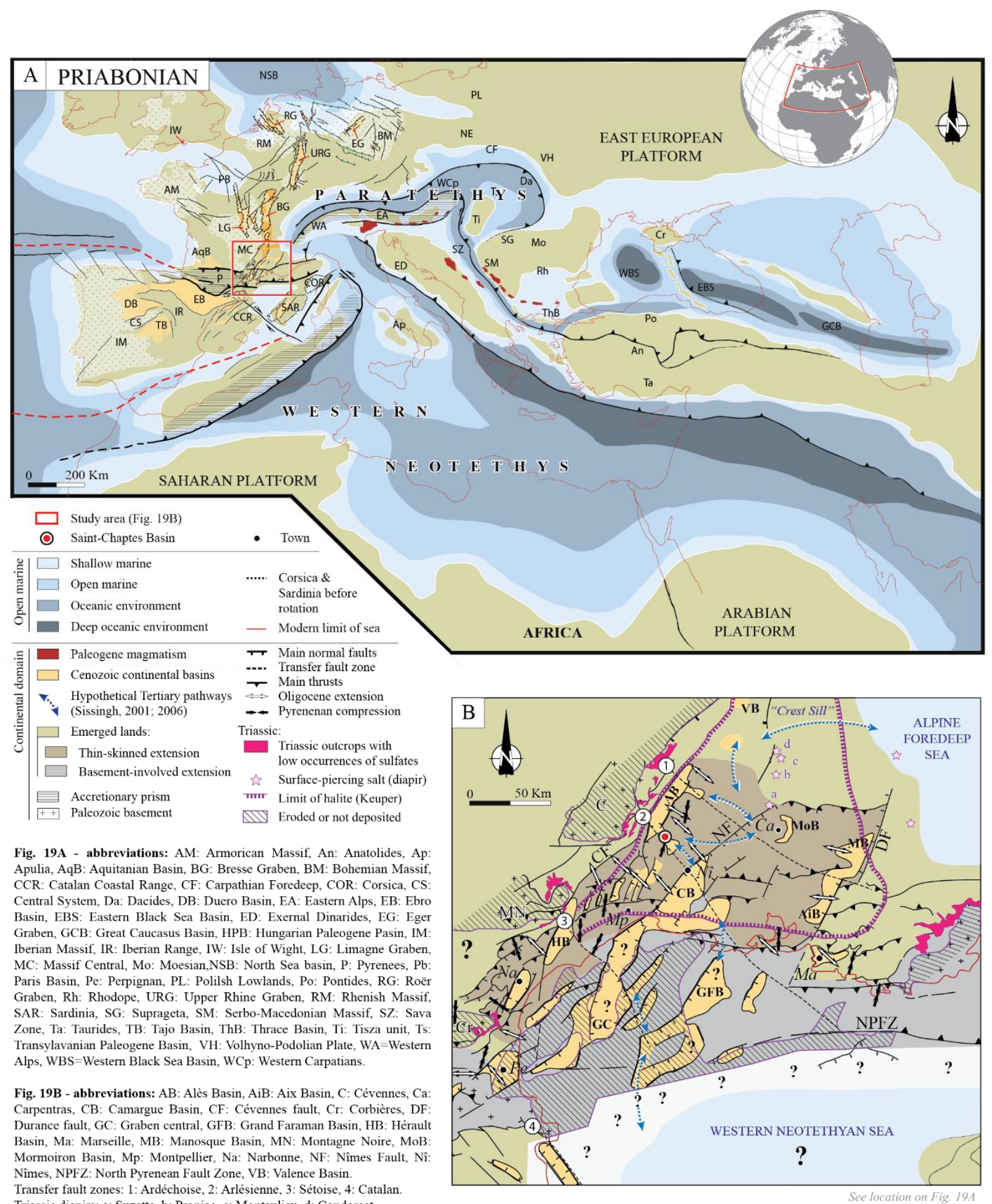

Transfer fault zones: 1: Ardéchoise, 2: Arlésienne, 3: Sétoise, 4: Catalan.

Triassic diapirs: a: Suzette, b: Propiac, c: Montaulieu, d: Condorcet.

Fig. 19. (A) Paleogeographic map with the main structural features of western Europe during the Priabonian, modified after Ziegler (1988); Anadón et al. (1989); Bois (1993); Gorini et al. (1994); Mauffret and Gorini, 1996; Rögl (1999); Séranne (1999); Gély and Sztrákos (2000); Casula et al. (2001); Sissingh (2001; 2006); Andeweg (2002); Meulenkamp and Sissingh (2003); Dèzes et al. (2004); Berger et al. (2005B); Bauer et al. (2016); and Ozsvárt et al. (2016). (B) Paleogeographic map of south-east France during Priabonian to Rupelian, modified after Dubois and Delfaud (1989); Bois (1993); Séranne et al. (1995); Guennoc et al. (2000); Lettéron et al. (2017). 
buried beneath Neogene cover of the Gulf of Lion, where the Pyrenean thrust belt collapsed in Oligocene to Miocene times (Gorini et al., 1991; Gorini, 1993; Viallard and Gorini, 1994). Dissolution of Keuper evaporites, exposed in the southern drainage basins, across the Pyrenean thrust and fold belt may have provided material for the sulfates found in the Priabonian St-Chaptes Basin.

Direct connections with marine environments are discarded since a set of saline lakes are intercalated between the St-Chaptes Basin and the Priabonian coastline of the Alpine Foredeep Sea to the east (Mormoiron, Valreas, Valence and Manosque basins via the Crest Sill, cf. Sissingh, 2001; 2006) and probably from the Western Neotethyan Sea to the south (Camargue, Grand Faraman and Central Graben) (Fig. 19B).

Tertiary offshore grabens in the Gulf of Lion (Fig. 19B) have been evidenced and mapped by various studies based on marine seismic interpretation (e.g. Gorini, 1993; Gorini et al., 1994; Séranne et al., 1995; Benedicto-Esteban, 1996; Guennoc et al., 2000). A limitation of considering the Tertiary offshore grabens as potential pathways for marine connections from the south, is the poorly-constrained age of such basins since syn-rift deposits have not been drilled (e.g. Gorini, 1993; Guennoc et al., 2000). The existence of significant topographic reliefs inherited from the Pyrenean orogeny in the Gulf of Lion, during the pre- and syn-rift periods has been evidenced by structural restorations based on marine seismic profiles. Paleo-elevations ranging from 1300 to 1500 meters have been estimated for the reliefs existing in the Gulf of Lion prior to rifting, i.e. in Priabonian times (Séranne et al., 1995; Benedicto et al., 1996). In addition, the southward thinning of the syn-rift series in offshore grabens (Gorini, 1993; Séranne, 1999) and the southern origin of the terrigenous material deposited in onshore grabens (e.g. Frédet, 1987) support the idea of a topographic barrier that may have prevented the connection of the Priabonian onshore basins with Western Neotethyan Sea to the south. However, the similarities in structural style and basin orientation between onshore and offshore grabens would suggest that the formation of offshore extensional basins (e.g. The Cathare Basin) started during the Priabonian (Gorini, 1993). Even though significant reliefs existed in the Gulf of Lion area during the Priabonian, these may have been deeply intersected by grabens, thus forming low-elevation corridors, favoring possible marine connections to the south. A similar structural and geomorphological configuration has been demonstrated in the Upper Rhine Graben (e.g. Roussé, 2006; Hinsken et al., 2007) (Fig. 1).

The lack of direct connection between the Saint-Chaptes area and the marine realm is supported by the trace element signature of carbonate deposits (high $\mathrm{Sr} / \mathrm{Ca}$ and low $\mathrm{Na} / \mathrm{Ca}$ ) in units U5 and U6. As a consequence, three possible local/regional origins of the salinity can be inferred for the Saint-Chaptes lake basin: 1) Hydrothermal springs with sulfate-rich waters deriving from circulations along the regional Triassic decollement level; 2) connections, at least temporary with neighboring saline lakes (e.g. Camargue or Mormoiron Basins); and/or 3) leaching of Triassic evaporites exposed by Pyrenean orogeny in the southernmost areas (> $100 \mathrm{~km}$ ) (e.g. Corbières). These conclusions deferred the problem to that of the origin of salinity in the neighboring lakes in the rhodanian basins or in the offshore Gulf of Lion grabens. Relationships between Priabonian-Rupelian evaporitic sedimentation and dissolution of Triassic salt diapirs has been evidenced in the Mormoiron Basin (Emre and Truc, 1978; Truc, 1978). A continental origin (recycling of Triassic evaporites) for Paleogene evaporites from the Valence Basin has been inferred from geochemical data and paleoecological analyses (Fontes et al., 1996). The possibility of the existence of marine connections through the "Crest Sill" as assumed by Sissingh (2001) seems therefore unlikely. In the rhodanian basins, Triassic 
salts are likely to be mainly supplied from the salt diapirs located in the Rhône Valley (e.g. Suzette, Propiac, Condorcet diapirs: location on Fig. 19B) or from the area located east of the Durance fault where Triassic formations may have cropped out during the Priabonian (Fig. 19B) as a result of the previous Pyrenean deformations (Guilhaumou et al., 1996). No data exist regarding the nature of the Priabonian deposits in the Gulf of Lion basins since this interval has never been drilled and/or formally dated (Guennoc et al., 2000). In the offshore rift basins, Tertiary deposits directly overlie the Paleozoic basement (Grand Faraman Graben) whereas a Mesozoic cover is preserved in the hanging walls of the Camargue Basin and the Central Graben (Fig. 19B). An erosion of Triassic evaporites in the Gulf of Lion area and their recycling in Priabonian lakes in the Camargue Basin and the Central Graben is therefore an hypothesis to be considered, provided that these basins have already functioned at that time.

The occurrence of benthic foraminifera of marine affinities in Western European Rift basin deposits has been commonly considered as an evidence of connection with marine environments (e.g. Merle and Michon, 2001), but such interpretations must be qualified since benthic foraminifera communities living in modern saline lakes that have never been connected with marine environments have been reported in a number of studies (e.g. Cann and De Deckker, 1981; Plaziat, 1991). In addition, some mollusc taxa of marine affinities such as Potamides that are common in the Saint-Chaptes Basin and in most of the European Priabonian saline lake environments are known to be able to adapt to athalassic lakes (Plaziat, 1993; Kowalke, 2006) and their occurrences in the depositional record should not be regarded as a robust evidence of marine connections (e.g. Briot, 2008). Marine connections, however, represent a possible cause for the existence of saline conditions in the Paleogene basins of the Gulf of Lion and the Camargue Basin. Structurally-inherited topographic depressions may have act as corridors between marine environments and continental lake basins as suggested by the development of SW-NEtrending grabens in the Gulf of Lion area may have cause marine incursions from the southern Neotethyan Sea (Fig. 19B).

\section{Conclusions}

The palaeoenvironmental and palaeogeographic significance of the Lower to Middle Priabonian carbonate succession (Lower Carbonate and Evaporite Formation: LCEF) from the Saint-Chaptes Basin has been deciphered by a detailed multi-proxy approach integrating sedimentological, paleontological and geochemical analyses. Five main stages of lacustrine system evolution have been identified within the LCEF succession: 1) Fresh-water closed lake under dry evaporitic climatic conditions (unit U1); 2) Fresh to brackish water lacustrine deltaic system with a mixed carbonate-siliciclastic sedimentation under relatively wet climatic conditions (unit U2); 3) Salt-water lacustrine carbonate system under humid climatic setting (unit U3); 4) Evaporitic lake (unit U4); and 5) Closed lake with shallow-water carbonate sedimentation under subtropical to Mediterranean climate with dry seasons (unit U5).

Palynological data, trace elements, stable isotopes and clay mineralogy support a depositional record of the Upper Eocene climatic deterioration. Aridification is evidenced to have started as early as the earliest Priabonian (unit U1: MP17A mammal zone). A continental large-scale transition from humid (units U2-U3) to dryer climatic conditions (units U4 to U6), has been recorded in the Lower to Mid Priabonian (MP17B-MP18 mammal zones) succession of the Saint-Chaptes Basin. This climate change could be 
correlated with the climate transition between Gypsum 3 and Lucina marls in the Paris Basin or Salt I and Green Marls II in the Upper Rhine Graben (Fig. 18).

The complete lack of purely stenohaline biota, the Na-depleted elemental signature of carbonates and the long distance $(>100 \mathrm{~km})$ from the closest marine environments suggest that the Saint-Chaptes lake probably mainly behave like an athalassic (inland) lake. However, the salt-water conditions evidenced by biological component and trace element signatures (high $\mathrm{Sr} / \mathrm{Ca}$ ratio) from U2 to U6 units are strongly indicative of transient connections with water bodies influenced by seawater. However supply of sulfates deriving from Triassic evaporates leaching and/or from fluid circulations linked to faults initiated during the Pyrenenan deformation cannot be ruled out. Maximum of connection with neighboring salt-lakes (Mormoiron Basin, Camargue and Central grabens, Hérault Basin) probably occurred during unit U3 and at the base of unit U5. Likely sources of Triassic salts are the salt-diapirs from the Rhône valley (e.g. Suzette diapir) but also paleo-outcrops of Triassic evaporites located east of the Durance fault or offshore in the Gulf of Lion. Paleogeographic reconstructions indicate also the possibility of marine incursions from the south, through the Camargue, Grand-Faraman and Central grabens in the Gulf of Lion (Fig. 19B).

\section{Acknowledgements}

This work is part of the PhD thesis of the first author $(A L)$ and was funded by IFP Energies nouvelles (grant number XRP09 001). Authors thank Jean Albert Rémy for usefull discussions on mammal biostratigraphy and regional geology. Ludovic Bruneau is thank for his help with clay mineral analyses. Critical comments that were provided by Sedimentary Geology reviewers and Associate Editor Brian Jones were very constructive and helpful in the revision of an early version of the manuscript. 


\section{Supplementary data}

Table A. Representative geochemical proxies with detection limits for ICP-MS analyses. *The digestion is only partial for some $\mathrm{Cr}$ and Ba minerals and some oxides of Al, $\mathrm{Hf}, \mathrm{Mn}$, Sn, Ta and Zr.

\begin{tabular}{lll}
\hline Element & Detection & Upper \\
& limit & Limit \\
\hline $\mathrm{Ag}$ & $2 \mathrm{ppb}$ & $100 \mathrm{ppm}$ \\
$\mathrm{Al} l^{*}$ & $0,01 \%$ & $10 \%$ \\
$\mathrm{As}$ & $0.1 \mathrm{ppm}$ & $10,000 \mathrm{ppm}$ \\
$\mathrm{Au}$ & $0.2 \mathrm{ppb}$ & $100 \mathrm{ppm}$ \\
$\mathrm{B} *$ & $20 \mathrm{ppm}$ & $2,000 \mathrm{ppm}$ \\
$\mathrm{Ba} *$ & $0.5 \mathrm{ppm}$ & $10,000 \mathrm{ppm}$ \\
$\mathrm{Bi}$ & $0.01 \mathrm{ppm}$ & $2,000 \mathrm{ppm}$ \\
$\mathrm{Ca}$ & $0,01 \%$ & $40 \%$ \\
$\mathrm{Cd}$ & $0.01 \mathrm{ppm}$ & $1,000 \mathrm{ppm}$ \\
$\mathrm{Co}$ & $0.1 \mathrm{ppm}$ & $50 \mathrm{ppm}$ \\
$\mathrm{Cr}$ & $0.5 \mathrm{ppm}$ & $10 \%$ \\
$\mathrm{Cu}$ & $0.01 \mathrm{ppm}$ & $10,000 \mathrm{ppm}$ \\
$\mathrm{Fe}$ & $0,01 \%$ & $30 \%$ \\
$\mathrm{Ga} *$ & $0.1 \mathrm{ppm}$ & $10,000 \mathrm{ppm}$ \\
$\mathrm{Hg}$ & $5 \mathrm{ppb}$ & $2,000 \mathrm{ppm}$ \\
$\mathrm{K}^{*}$ & $0,01 \%$ & $5 \%$ \\
$\mathrm{La}$ & $0.5 \mathrm{ppm}$ & $10,000 \mathrm{ppm}$ \\
$\mathrm{Mg} *$ & $0,01 \%$ & $5 \%$ \\
$\mathrm{Mn} *$ & $1 \mathrm{ppm}$ & $10,000 \mathrm{ppm}$ \\
$\mathrm{Mo}$ & $0.01 \mathrm{ppm}$ & $10 \%$ \\
$\mathrm{Na} *$ & $0.001 \%$ & $2,000 \mathrm{ppm}$ \\
$\mathrm{Ni}$ & $0.1 \mathrm{ppm}$ & $100 \mathrm{ppm}$ \\
$\mathrm{P}^{*}$ & $0.001 \%$ & $5 \%$ \\
$\mathrm{~Pb}$ & $0.01 \mathrm{ppm}$ & $10,000 \mathrm{ppm}$ \\
$\mathrm{S}$ & $0,02 \%$ & $10 \%$ \\
$\mathrm{Sb}$ & $0.02 \mathrm{ppm}$ & $2,000 \mathrm{ppm}$ \\
$\mathrm{Sc}$ & $0.1 \mathrm{ppm}$ & $100 \mathrm{ppm}$ \\
$\mathrm{Se}$ & $0.1 \mathrm{ppm}$ & $100 \mathrm{ppm}$ \\
$\mathrm{Sr}$ & $0.5 \mathrm{ppm}$ & $10,000 \mathrm{ppm}$ \\
$\mathrm{Te}$ & $0.02 \mathrm{ppm}$ & $1,000 \mathrm{ppm}$ \\
$\mathrm{Th}$ & $0.1 \mathrm{ppm}$ & $2,000 \mathrm{ppm}$ \\
$\mathrm{Ti}$ & $0,00 \%$ & $5 \%$ \\
$\mathrm{Tl}$ & $0.02 \mathrm{ppm}$ & $1,000 \mathrm{ppm}$ \\
$\mathrm{U}^{*}$ & $0.05 \mathrm{ppm}$ & $2,000 \mathrm{ppm}$ \\
$\mathrm{V}^{*}$ & $2 \mathrm{ppm}$ & $10,000 \mathrm{ppm}$ \\
$\mathrm{W} *$ & $0.05 \mathrm{ppm}$ & $100 \mathrm{ppm}$ \\
$\mathrm{Zn}$ & $0.1 \mathrm{ppm}$ & $10,000 \mathrm{ppm}$ \\
\hline & & \\
\hline
\end{tabular}

Lettéron, A., Hamon, Y., Founier, F., Séranne, M., Pellenard, P. and Jospeh, P., 2018. Reconstrcutnion of a saline, lacustrine carbonate system (Priabonian, St-Chaptes Basin, SE France): depositional models, paleogeogrpahix and paleoclimatic implications. Sedimentary Geology, 367, 20-47. 
Table B. Carbon and oxygen stable isotope database from this study (samples location are located on Figure 4, Saint-Chaptes Basin, SE France. Refer to the text for lithofacies code (cf. Table 1) and diagenetic classes (cf. section: carbon and oxygen stable isotopes).

\begin{tabular}{|c|c|c|c|c|c|c|}
\hline Unit & Sample & Elevation $(\mathbf{m})$ & $\delta 180$ (\% vs V-PDB) & $\delta 13 C$ (\% vs V-PDB) & Lithofacies code & Diagenetic class \\
\hline U1 & EUZ & 1,26 & $-4,84$ & $-4,94$ & P3 & III \\
\hline U1 & G001 & 7,60 & $-3,46$ & $-5,35$ & P3 & III \\
\hline U1 & G002 & 3,48 & $-4,09$ & $-1,58$ & MTC 1 & I \\
\hline U1 & G154 & 30,78 & 0,82 & $-1,72$ & MTC 1 & I \\
\hline U1 & G156 & 32,29 & $-2,48$ & $-2,65$ & MTC 1 & I \\
\hline U1 & G157 & 32,96 & $-2,31$ & $-1,70$ & MTC 1 & I \\
\hline U1 & G158 & 33,29 & $-2,85$ & $-2,36$ & MTC 1 & I \\
\hline $\mathrm{U} 2$ & G003 & 43,01 & $-3,20$ & $-0,03$ & MTC 2 & I \\
\hline $\mathrm{U} 2$ & G004 & 43,96 & $-3,14$ & 0,04 & MTC 2 & I \\
\hline $\mathrm{U} 2$ & G005 & 44,75 & $-3,01$ & $-0,03$ & MTC 2 & I \\
\hline $\mathrm{U} 2$ & G006 & 45,69 & $-3,19$ & 0,14 & MTC 2 & I \\
\hline $\mathrm{U} 2$ & G007 & 47,32 & $-3,08$ & 0,50 & MTC 2 & I \\
\hline $\mathrm{U} 2$ & G008 & 49,27 & $-3,18$ & 0,35 & MTC 2 & I \\
\hline $\mathrm{U} 2$ & G009 & 50,15 & $-3,23$ & 0,16 & MTC 2 & I \\
\hline $\mathrm{U} 2$ & G010 & 51,16 & $-3,06$ & 0,32 & MTC 2 & I \\
\hline $\mathrm{U} 2$ & G012 & 54,49 & $-2,84$ & 0,55 & MTC 2 & I \\
\hline $\mathrm{U} 2$ & G013 & 55,60 & $-3,29$ & 0,58 & MTC 2 & I \\
\hline $\mathrm{U} 2$ & G014 & 56,74 & $-3,28$ & 0,71 & MTC 2 & I \\
\hline $\mathrm{U} 2$ & G015 & 57,61 & $-3,36$ & 0,45 & MTC 2 & I \\
\hline $\mathrm{U} 2$ & G016 & 58,61 & $-3,98$ & 0,59 & MTC 2 & I \\
\hline $\mathrm{U} 2$ & G017 & 59,89 & $-2,50$ & 0,17 & MTC 2 & I \\
\hline $\mathrm{U} 2$ & G018 & 61,42 & $-3,18$ & 0,30 & MTC 2 & I \\
\hline U3 & G028 & 69,32 & $-3,06$ & 0,32 & SLC 4 & I \\
\hline U3 & G029 & 70,00 & $-3,98$ & $-1,67$ & SLC 4 & I \\
\hline U3 & G030 & 70,36 & $-3,31$ & $-1,64$ & SLC 4 & I \\
\hline U3 & G031 & 70,85 & $-2,90$ & 0,16 & SLC 4 & I \\
\hline U3 & G033 & 72,26 & $-4,95$ & $-0,41$ & SLC 4 & I \\
\hline U3 & G035 & 73,30 & $-4,20$ & $-1,48$ & SLC 4 & I \\
\hline U3 & G036 & 74,33 & $-4,50$ & $-1,27$ & SLC 4 & I \\
\hline U3 & G037 & 74,93 & $-2,88$ & $-2,20$ & SLC 4 & I \\
\hline U3 & G038 & 75,13 & $-4,42$ & $-1,43$ & SLC 4 & I \\
\hline U3 & G039 & 76,00 & $-3,78$ & $-1,19$ & SLC 4 & I \\
\hline U3 & G040 & 76,36 & $-3,89$ & $-1,20$ & SLC 4 & I \\
\hline U3 & G042 & 77,80 & $-5,16$ & $-1,93$ & SLC 8 & II \\
\hline U3 & G043 & 78,75 & $-4,16$ & $-0,03$ & SLC 4 & I \\
\hline U3 & G044 & 79,50 & $-3,42$ & $-1,59$ & SLC 4 & I \\
\hline U3 & G045 & 80,11 & $-4,53$ & $-0,63$ & SLC 4 & I \\
\hline U3 & G160 & 90,36 & $-3,54$ & $-1,54$ & SLC 4 & I \\
\hline U3 & G161 & 91,32 & $-6,29$ & $-2,77$ & SLC 8 & II \\
\hline $\mathrm{U} 4$ & G162 & 120,92 & $-3,34$ & $-3,69$ & SLC 3 & IV \\
\hline U4 & G163 & 121,53 & $-3,48$ & $-4,76$ & SLC 3 & IV \\
\hline $\mathrm{U} 4$ & G164 & 125,30 & $-4,20$ & $-2,67$ & SLC 3 & IV \\
\hline U4 & G165 & 126,03 & $-4,26$ & $-2,91$ & SLC 3 & IV \\
\hline U5 & G047 & 147,96 & $-3,60$ & 1,02 & SLC 2 & I \\
\hline U5 & G050 & 151,82 & $-1,73$ & 1,75 & SLC 5 & I \\
\hline
\end{tabular}

Lettéron, A., Hamon, Y., Founier, F., Séranne, M., Pellenard, P. and Jospeh, P., 2018. Reconstrcutnion of a saline, lacustrine carbonate system (Priabonian, St-Chaptes Basin, SE France): depositional models, paleogeogrpahix and paleoclimatic implications. Sedimentary Geology, 367, 20-47. 


\begin{tabular}{|c|c|c|c|c|c|c|}
\hline U5 & G052 & 156,00 & $-3,21$ & 1,20 & SLC 5 & I \\
\hline U5 & G053 & 156,27 & $-0,84$ & 1,80 & SLC 5 & I \\
\hline U5 & G054 & 157,95 & $-5,35$ & 0,48 & SLC 6 & II \\
\hline U5 & G059 & 167,04 & $-5,06$ & 1,50 & SLC 2 & I \\
\hline U5 & G063 & 172,91 & $-2,13$ & 1,11 & SLC 5 & I \\
\hline U5 & G064 & 173,63 & $-2,42$ & 1,20 & SLC 2 & I \\
\hline U5 & G067 & 177,68 & $-1,38$ & 1,68 & SLC 5 & I \\
\hline U5 & G069 & 179,84 & $-2,23$ & 1,22 & SLC 2 & I \\
\hline U5 & G070 & 180,70 & $-5,25$ & 0,95 & SLC 2 & I \\
\hline U5 & G071 & 181,26 & $-2,86$ & 1,36 & SLC 2 & I \\
\hline U5 & G072 & 181,87 & $-2,33$ & 1,37 & SLC 2 & I \\
\hline U5 & G073 & 182,48 & $-2,55$ & 0,99 & SLC 2 & I \\
\hline U5 & G075 & 184,30 & $-5,71$ & 1,14 & SLC 2 & I \\
\hline U5 & G076 & 184,78 & $-3,83$ & 1,55 & SLC 2 & I \\
\hline U5 & G077 & 185,31 & $-2,65$ & 1,24 & SLC 2 & I \\
\hline U5 & G078 & 186,10 & $-3,38$ & 1,26 & SLC 2 & I \\
\hline U5 & G079 & 189,88 & $-2,65$ & 0,88 & SLC 2 & I \\
\hline U5 & G080 & 190,46 & $-2,88$ & 1,33 & SLC 2 & I \\
\hline U5 & G081 & 194,90 & $-2,84$ & 1,34 & SLC 2 & I \\
\hline U5 & G082 & 196,17 & $-4,52$ & 0,18 & SLC 6 & II \\
\hline U5 & G083 & 196,77 & $-5,29$ & 0,69 & SLC 2 & I \\
\hline U5 & G084 & 197,56 & $-4,20$ & 1,41 & SLC 2 & I \\
\hline U5 & G085 & 200,27 & $-4,13$ & 1,30 & SLC 2 & I \\
\hline U5 & G086 & 201,89 & $-4,80$ & 0,57 & SLC 6 & II \\
\hline U5 & G087 & 202,59 & $-4,83$ & 0,81 & SLC 2 & I \\
\hline U5 & G089 & 204,50 & $-4,89$ & 0,21 & SLC 6 & II \\
\hline U5 & G090 & 206,47 & $-5,84$ & 0,80 & SLC 2 & I \\
\hline U5 & G092 & 208,47 & $-5,33$ & $-0,19$ & SLC 6 & II \\
\hline U5 & G093 & 209,15 & $-5,65$ & 0,82 & SLC 2 & I \\
\hline U5 & G120 & 210,00 & $-4,94$ & 0,61 & SLC 6 & II \\
\hline U5 & G121 & 210,42 & $-5,72$ & 0,04 & SLC 6 & II \\
\hline U5 & G122 & 211,66 & $-6,53$ & 0,10 & SLC 6 & II \\
\hline U5 & G123 & 212,08 & $-6,04$ & 0,18 & SLC 6 & II \\
\hline U5 & G125 & 212,62 & $-5,68$ & 0,32 & SLC 6 & II \\
\hline U5 & G124 & 212,84 & $-5,39$ & 0,43 & SLC 6 & II \\
\hline U5 & G126 & 213,44 & $-5,90$ & 0,27 & SLC 6 & II \\
\hline U5 & G127 & 214,62 & $-4,84$ & 0,22 & SLC 6 & II \\
\hline U5 & G128 & 215,27 & $-3,53$ & 0,73 & SLC 6 & II \\
\hline U5 & G129 & 215,84 & $-4,27$ & 0,65 & SLC 6 & II \\
\hline U5 & G131 & 216,15 & $-3,70$ & 1,30 & SLC 2 & I \\
\hline U5 & G130 & 216,52 & $-4,50$ & 0,85 & SLC 6 & II \\
\hline U5 & G132 & 216,94 & $-4,05$ & 0,75 & SLC 6 & II \\
\hline U5 & G133 & 217,20 & $-3,51$ & 0,67 & SLC 6 & II \\
\hline U5 & G134 & 217,84 & $-4,45$ & 0,45 & SLC 6 & II \\
\hline U5 & G135 & 218,56 & $-4,87$ & 0,95 & SLC 6 & II \\
\hline U6 & G101 & 218,99 & $-4,36$ & $-0,32$ & MTC 3 & I \\
\hline U6 & G136 & 219,25 & $-5,12$ & 0,00 & SLC 6 & II \\
\hline U6 & G137 & 219,63 & $-3,12$ & $-0,55$ & SLC 2 & I \\
\hline U6 & G138 & 220,12 & $-4,07$ & $-1,42$ & SLC 2 & I \\
\hline U6 & G105 & 223,11 & $-5,42$ & $-0,54$ & SLC 6 & II \\
\hline
\end{tabular}

Lettéron, A., Hamon, Y., Founier, F., Séranne, M., Pellenard, P. and Jospeh, P., 2018. Reconstrcutnion of a saline, lacustrine carbonate system (Priabonian, St-Chaptes Basin, SE France): depositional models, paleogeogrpahix and paleoclimatic implications. Sedimentary Geology, 367, 20-47. 


\begin{tabular}{lllllll} 
U6 & G106 & 223,42 & $-4,46$ & $-0,75$ & SLC 2 & I \\
U6 & G107 & 223,64 & $-6,02$ & $-1,01$ & SLC 6 & II \\
U6 & G108 & 225,48 & $-5,73$ & $-1,03$ & SLC 6 & II \\
U6 & G109 & 226,39 & $-4,86$ & $-0,69$ & SLC 6 & II \\
U6 & G110 & 227,02 & $-4,64$ & $-1,25$ & SLC 2 & I \\
U6 & G111 & 227,33 & $-3,61$ & $-0,94$ & SLC 2 & I \\
U6 & G112 & 227,95 & $-6,34$ & $-1,00$ & SLC 3 & II \\
U6 & G113 & 228,85 & $-4,02$ & $-0,61$ & MTC 3 & I \\
U6 & G114 & 230,02 & $-5,99$ & $-1,83$ & SLC 8 & II \\
\hline CSF & G117 & 233,61 & $-7,50$ & $-0,71$ & MTC 4 & II \\
\hline
\end{tabular}




\section{References}

Alabouvette, B., Aubague, M., Bambier, A., Feist, R., Palloc, H., 1982. Notice explicative. Carte géologique de France (1/50 000), Lodève (0989). Bureau de Recherches Géologiques et Minières (BRGM), Orléans (52 pp.).

Alabouvette B., Chedhomme, J., Frédet, J.M., Lartaud, V., 1983. Inventaire des ressources nationale de charbon : lignites du fossé d'Alès-Barjac. Mémoire du Bureau de Recherches Géologiques et Minières (BRGM), Orléans (No. 83, 63 pp.)

Alonso-Zarza A.M., 2003. Palaeoenvironmental significance of palustrine carbonates and calcretes in the geological record. Earth-Science Reviews 60, 261-298.

Anadón, P., Cabrera, L., Julia, R., Roca, E., Rosell, L., 1989. Lacustrine Oil-Shale basins in Tertiary Grabens from NE Spain (Western European Rift System). Palaeogeography, Palaeoclimatology, Palaeoecology 70, 7-28.

Andeweg, B., 2002. Cenozoic Tectonic Evolution of the Iberian Peninsula: Effects and Causes of Changing Stress Fields. (Ph.D. Thesis). Vrije Universiteit Amsterdam, The Netherlands (174 pp.).

Andrews, J.E., Riding, R., Dennis, P.F., 1997. The stable isotope record of environmental and climatic signals in modern terrestrial microbial carbonates from Europe. Palaeogeography, Palaeoclimatology, Palaeoecology 129, 171-189.

Apostolescu, V., Dellenbach, J., 1999. Les ostracodes Oligocènes de Haute-Provence - Une contribution à la paléobiogéographie de l'Oligocène. Géologie Méditerranéenne 26 (3-4) 153-183.

Archer, M., Godthelp, H., Hand, S.J., Megirian, D., 1989. Fossil mammals of Riversleigh, northwestern Queensland: preliminary overview of biostratigraphy, correlation and environmental change. Australian Zoologist 25 (2), 29-65.

Arenas, C., Casanova, J., Pardo, G., 1997. Stableisotope characterization of the Miocene lacustrine systems of Los Monegros (Ebro Basin, Spain): palaeogeographic and palaeoclimatic implications. Palaeogeography, Palaeoclimatology, Palaeoecology 128, 133-155.

Arenas, C., Cabrera, L., Ramos, E., 2007. Sedimentology of tufa facies and continental microbialites from the Paleogene of Mallorca Island (Spain). Sedimentary Geology 197, 1-27.

Arthaud, F., Séguret, M., 1981. Les structures pyrénéennes du Languedoc et du Golfe du Lion (Sud de la France). Bulletin de la Société Géologique de France $23(1), 51-63$

Armenteros, I., Daley, B., García, E., 1997. Lacustrine and palustrine facies in the Bembridge Limestone (late Eocene, Hampshire Basin) of the Isle of Wight, southern England. Palaeogeography, Palaeoclimatology, Palaeoecology 128, 111-132.

Aubry, M.-P., 1986. Paleogene calcareous nannoplankton biostratigraphy of northwestern Europe. Palaeogeography, Palaeoclimatology, Palaeoecology 55, 267-334.

Bastide, F., 2014. Synthèse de l'évolution de la plateforme urgonienne (Barrémien tardif à Aptien précoce) du Sud-Est de la France: facies, micropaléontologie, géochimie, géométries, paléotectonique et géomodélisation. (Ph.D. Thesis). Université de Grenoble, France (456 pp.).

Bauer, H., Bessin P., Saint-Marc, P., Châteauneuf, J.-J., Bourdillon, C., Wyns, R., Guillocheau, F., 2016. The Cenozoic history of the Armorican Massif: new insights from the deep CD81 Borehole (Rennes Basin, France). Compte Rendus Geoscience, 348, 387-397.

Becker, D., 2003. Paléoécologie et paléoclimats de la Molasse du Jura (Oligo-Miocène): apport des Rhinocerotoidea (Mammalia) et des minéraux argileux. (Ph.D. Thesis). GeoFocus 9. Université de Fribourg, Switzerland (327 pp.).

Benedicto-Esteban, A., 1996. Modèles tectonosédimentaires de bassins en extension et style structural de la marge passive du golfe du lion (partie nord), sudest France. (Ph.D. Thesis). Université de Montpellier, France (255 pp.).

Berger, G.-M., Alabouvette, B., Bessière, G., Bilotte, M., Crochet, B., Dubar, M., Marchal, J.-P., Tambareau, Y., Villatte, J., Viallard, P., 1997. Notice explicative. Carte géologique de France (1/50 000), Tuchan (1078). Bureau de Recherches Géologiques et Minières (BRGM), Orléans (113 pp.)

Berger, J.-P., Reichenbacher, B., Becker, D., Grimm, M., Grimm, K., Picot, L., Storni, A., Pirkenseer, C., Schaefer, A., 2005 (A). Eocene-Pliocene time scale and stratigraphy of the Upper Rhine Graben (URG) and the Swiss Molasse Basin (SMB). International Journal of Earth Sciences, Geologische Rundschau 94, 711-731.

Berger, J.-P., Reichenbacher, B., Becker, D., Grimm, M., Grimm, K., Picot, L., Storni, A., Pirkenseer, C., Derer, C., Schaefer, A., 2005 (B). Palaeogeography of the Upper Rhine Graben (URG) and the Swiss Molasse Basin (SMB) from Eocene to Pliocene. International Journal of Earth Sciences, Geologische Rundschau 94, 697-710.

Blanc-Valleron, M.M., 1991. Les formations paléogènes évaporitiques du bassin potassique de Mulhouse et des bassins plus septentrionaux d'Alsace. Mémoire du Bureau de Recherches Géologiques et Minières (BRGM), Orléans (No. 204, 349 pp.).

Blanc-Valleron, M.M., Schuler, M., 1997. The Salt Basins of Alsace (Southern Rhine Graben). In: Busson, G., Schreiber, B.C. (Eds.), Sedimentary Deposition in Rift and Foreland Basins in France and Spain. Columbia Univ. Press, New York, pp. 95-135.

Bodergat, A.-M., Briot, D., Hugueney, M., Poidevin, J.-L., Picot, L., Giraud, F., Berger, J.P., Levy, A., Poignant, A., 1999. Incursions marines dans l'environnement lacustre du rift oligocène de Limagne (Massif Central, France): apport des organisms halophiles et des isotopes du strontium, datation par les mammifères. Bulletin de la Société Géologique de France, 170, 499-511.

Bois, C., 1993. Initiation and evolution of the OligoMiocene rift basins of southwestern Europe: contribution of deep seismic reflection profiling. Tectonophysics 226 , 227-252.

Bojanowski, M., Jaroszewicz, E., Košir, A., Koziński, M., Marynowski, L., Wysocka, A., Derkowski, A., 2016. Root-related rhodochrosite and concretionary siderite formation in oxygen-deficient conditions induced by a ground-water table rise. Sedimentology 63, 523-551.

Briais, J., 2015. Le Cénozoïque du bassin de Paris : un enregistrement sédimentaire haute résolution des déformations lithosphériques en régime de faible subsidence. (Ph.D. Thesis). Université de Rennes I, France (450 pp.).

Briot, D., Poidevin, J.L., 1998. Stratigraphie ${ }^{87} \mathrm{Sr} /{ }^{86} \mathrm{Sr}$ de quelques laminites carbonates du Rupélien inférieur du fosse de Limagne: incursions marines dans le rift du

Lettéron, A., Hamon, Y., Founier, F., Séranne, M., Pellenard, P. and Jospeh, P., 2018. Reconstrcutnion of a saline, lacustrine carbonate system (Priabonian, St-Chaptes Basin, SE France): depositional models, paleogeogrpahix and paleoclimatic implications. Sedimentary Geology, 367, 20-47. 
Massif central français? Compte Rendu s de l'Académie des Sciences de Paris 236, 479-483.

Briot, D., 2008. Sr isotopes of the shells of the euryhaline gastropod Potamides lamarcki from the Oligocene of the French Massif Central and Paris Basin A clue to its habitats. Palaeogeography, Palaeoclimatology, Palaeoecology 268 (1-2), 116-122.

Brown, R.W., 1962. Paleocene flora of the Rocky Mountains and Great Plains. U.S. Geological Survey Professional Paper 375, 1-119.

Brunet, M., Franzen, J.L., Godinot, M., Hooker, J.J., Legendre, S., Schmidt-Kittler, N., Vianey-Liaud, M., 1987. European reference levels and correlation tables. In: Schmidt-Kittler, N. (Ed.), International symposium on Mammalian Biostratigraphy and Paleoecology of the European Paleogene. Münchner Geowissenschaftliche Abhandlungen Reihe A, Geologie und Paläontologie, 10, Munich, pp. 13-31.

Cann, J.H., De Deckker, P., 1981. Fossil Quaternary and living foraminifera from athalassic (non-marine) saline lakes, southern Australia. Journal of Paleontology 55 (3), 660-670.

Casula, G., Cherchi, A., Montadert, L., Murru, M., Sarria, E., 2001. The Cenozoic graben system of Sardinia (Italy): geodynamic evolution from new seismic and field data. Marine and Petroleum Geology 18, 863-888.

Cavelier, C., 1965. Le Sannoisien de Sannois (Seine-etOise) dans le cadre du Bassin de Paris et signification stratotypique. Bulletin de la Société géologique de France, 7 (28), 228-238.

Chaboureau, A.-C., Donnadieu, Y., Sepulchre, P., Robin, C., Guillocheau, F., Rohais, S., 2012. The Aptian evaporites of the South Atlantic: a climatic paradox? Climate of the Past 8, 1047-1058.

Châteauneuf, J.-J., 1980. Palynostratigraphie et paleoclimatology de l'Eocène supérieur et de I'Oligocène du Bassin de Paris. (Ph.D. Thesis). Mémoire du Bureau de Recherches Géologiques et Minières (BRGM) 116, Université Pierre et Marie Curie, France, (357 pp.).

Châteauneuf, J.-J., Gruas-Cavagnetto, C., 1978. Les zones de Wetzeliellaceae (Dinophyceae) du bassin de Paris. Comparaison et corrélations avec les zones du Paléogène des bassins du Nord-Ouest de l'Europe. Bulletin du Bureau des recherches géologiques et minières (BRGM), Orléans, (2), 59-93.

Chivas, A.R., Andrews, A.S., Lyons, W.B., Bird, M.I., Donnelly, T.H., 1991. Isotopic constraints on the origin of salts in Australian playas. 1. Sulphur. Palaeogeography, Palaeoclimatology, Palaeoecology 84 (1-4), 309-332.

Chivas, A.R., De Deckker, P., Cali, J.A., Chapman, A., Kiss, E., Shelley, J.M.G., 1993. Coupled stable isotope and trace-element measurements of lacustrine carbonates as paleoclimatic indicators. In: Swart, P.K., Lohmann, K.C., McKenzie, J., Savin, S. (Eds.), Climate Change in Continental Isotopic Records. American Geophysical. Union, Washington D.C. Geophysical Monograph 78, pp. 113-121.

Cody, R.D., 1979. Lenticular gypsum: occurrences in nature and experimental determinations of effects of soluble green plant material on its formation: Journal of Sedimentary Petrology 49, 1015-1028.

Collinson, M.E., Fowler, K., Boulter, M.C., 1981. Floristic changes indicate a cooling climate in the Eocene of southern England. Nature 291, 315-317.

Collinson, M.E., 2001. Cainozoic ferns and their distribution. Brittonia 53 (2) 173-235.

Collinson, M.E., 2002. The ecology of Cainozoic ferns. Review of Palaeobotany and Palynology 119, 51-68.
Colson, J., Cojan, I, Thiry, M., 1998. A gydrogeological model for palygorskite formation in the Danian continental facies of the Provence Basin (France). Clay Minerals 33 (2), 333-347.

Costeur, L., Balme, C., Legal, S., 2009. Early Oligocene Mammal Tracks from Southeastern France. Ichnos 16, 257-267.

Costeur, L., Balme, C., Legal, S., 2011. Nouvelles découvertes d'empreintes de pas de mammifères dans I'Oligocène du Parc du Lubéron. Courrier scientifique du Parc naturel régional du Lubéron et de la Réserve de biosphère Lubéron-Lure 10, 48-59.

Cula, P., Courel, L., 1987. Les grès inférieurs du Trias Cévenol: systèmes sédimentaires fluviatiles et lagunomarins. Géologie Alpine, Mémoire Hors-série, 13, 103-111.

Curial, A., Moretto, R., 1997. The Salt Basin of Bresse. In: Busson, G., Schreiber, B.C. (Eds.), Sedimentary deposition in Rift and Foreland Basins in France and Spain. Columbia Univ. Press, New York, pp. 136-193.

Dahanayake, K., 1977. Classification of oncoids from the Upper Jurassic carbonates of the French Jura. Sedimentary Geology 18, 337-353.

Daley, B., 1972. Macroinvertebrate assemblages from the Bembridge marls (Oligocene) of the Isle of Wight, England, and their environmental significance. Palaeogeography, Palaeoclimatology, Palaeoecology 11, 11-32.

Depéret, C., 1917. Monographie de la faune de mammifères fossiles du Ludien inférieur d'Euzet-les-Bains (Gard). Annales de l'Université de Lyon, Sciences, Médecine, Lyon, (No. 40-288 pp.).

Destombes, J.P., 1962. Description géologique du bassin oligocène de Manosque-Forcalquier (Lubéron occidental). Bulletin du Service de la Carte Géologique de France 58 (266), 461-558.

Dèzes, P., Schmid, S.M., Ziegler, P.A., 2004. Evolution of the European Cenozoic Rift System: interaction of the Alpine and Pyrenean orogens with their foreland lithosphere. Tectonophysics 389, 1-33.

Dromart, G., Dumas, D., 1997. The Salt Basin of Valence (France). In: Busson, G., Schreiber, B.C. (Eds.), Sedimentary deposition in Rift and Foreland Basins in France and Spain. Columbia Univ. Press, New York, pp. 195-239.

Dubois, P., Delfaud, J., 1989. Le bassin du Sud-Est. In: Association des Sédimentologistes Français (Ed.), Dynamique et méthodes d'études des bassins sédimentaires. Technip, Paris, pp. 277-297.

Ducreux, J.-L., 1987. Nature et origine du détritiqme argilo-sableux dans le bassin Oligocène de Manosque (Alpes de Haute-Provence). Géologie Alpine 13, 397-401 Dumas, D., 1987. La sédimentation détritique dans le fossé salifère paleogène de Valence (Sud-Est de la France). Géologie Alpine 13, 403-407.

Dunham, R.J., 1962. Classification of carbonate rocks according to depositional texture. In: Ham, W.E. (Ed.), Classification of Carbonate Rocks. American Association of Petroleum Geologists, AAPG Memoir 1, Tulsa, pp. 108-121.

Duringer, P., 1988. Les conglomérats des bordures du rift Cénozoïque Rhénan. Dynamique sédieemntaire et contrôle climatique. (Ph.D. Thesis). Université de Strasbourg, France (278 pp.).

Ehrmann, W.U., Mackensen, A., 1992. Sedimentological evidence for the formation of an East Antarctic ice sheet in Eocene-Oligocene time. Palaeogeography, Palaeoclimatology, Palaeoecology 93, 85-112.

Ellenberger, P., 1980. Sur les empreintes de pas des gros mammifères de l'Eocène supérieur de Garrigues-

Lettéron, A., Hamon, Y., Founier, F., Séranne, M., Pellenard, P. and Jospeh, P., 2018. Reconstrcutnion of a saline, lacustrine carbonate system (Priabonian, St-Chaptes Basin, SE France): depositional models, paleogeogrpahix and paleoclimatic implications. Sedimentary Geology, 367, 20-47. 
Ste-Eulalie (Gard). Palaeovertebrata, Montpellier, Mém. Jubil. R. Lavocat, 37-78.

Ellenberger, P., Freytet, P., Plaziat, J.-C., Bessière, G., Viallard, P., Berger, G.-M., Marchal, J.-P. 1987. Notice explicative. Carte géologique de France (1/50 000), Capendu (1060). Bureau de Recherches Géologiques et Minières (BRGM), Orléans (88 pp.).

Emre, T., Truc, G., 1978. Mise en évidence d'un contact discordant Oligocène-Tiras dans le massif de Suzette. Implications tectoniques et conséquences sur l'origine des évaporites ludiennes du bassin de Mormoiron (Vaucluse). Géologie Alpine 54, 17-23.

Escarguel, G., Marandat, B., Legendre, S., 1997. Sur l'âge numérique des faunes de mammifères du Paléogène d'Europe occidentale, en particulier celles de I'Eocène inférieur et moyen. Mémoire de l'Ecole Pratique des Hautes Etudes (EPHE), Montpellier, France, 21, 443460

Esu, D., Girotti, O., 2010. The late Oligocene molluscan fauna from Otranto (Apulia, southern Italy): an example of alternating freshwater, lagoonal and emerged environments. Palaeontology 53, 137-174.

Feist-Castel, M., 1971. Sur les charophytes fossiles du bassin Tertiaire d'Alès (Gard). Geobios 4 (3), 157-172.

Finkelstein, D.B., Hay, R.L., Altaner, S.P., 1999. Origin and diagenesis of lacustrine sediments, upper Oligocene Creede Formation, southwestern Colorado. Geological Society of America Bulletin 111, 1175-1191.

Flügel, E., 2010. Microfacies of carbonate rocks. 2nd edition, Springer, Berlin, Heidelberg, New York.

Folk, R.L., Chafetz, H.S., Tiezzi, P.A., 1985. Bizarre forms of depositional and diagenetic calcite in hot-spring travertines, central Italy. In: Schneidermann N., Harris, P.M. (Eds.), Carbonate Cements. SEPM Special Publication 36, pp. 349-369.

Fontes, J.-C, Filly, A., Gaudant, J., Duringer, P., 1991. Origine continentale des évaporites paléogènes de Haute Alsace: arguments paléoécologiques, sédimentologiques et isotopiques. Bulletin de la Société géologique de France 162, 725-737.

Fontes, J.-C., Gaudant, J., Mélières, F., Filly, A., Schlund, J.-M., 1996. Origine continentale des évaporites paléogènes du fossé de Valence (Drôme): données minéralogiques, isotopiques et paléoécologiques. Bulletin de la société géologique de France 167 (4), 475-481.

Frédet, J.M., 1987. Tectonique et sédimentation en domaine continentale : évolution du basin paléogène d'Alès (Gard). (Ph.D. Thesis). Université Claude Bernard, Lyon, France (244 pp.)

Freytet, P., 1973. Petrography and paleo-environement of continental carbonate deposits with particular reference to the upper cretaceous and lower Eocene of Languedoc (Southern France). Sedimentary Geology 10, 25-60.

Freytet, P, Verrecchia, E.P., 2002. Lacustrine and palustrine carbonate petrography: an overview. Journal of Paleolimnology 27 (2), 221-237.

Gale, A.S., Huggett, J.M., Pälike, H., Laurie, E., Hailwood, E.A., Hardenbol, J., 2006. Correlation of Eocene-Oligocene marine and continental records: orbital cyclicity, magnetostratigraphy and sequence stratigraphy of the Solent Group, Isle of Wight, UK. Journal of the Geological Society of London 163, 401-415

Gandin, A., Capezzuoli, E., 2014. Travertine: distinctive depositional fabrics of carbonates from thermal spring systems. Sedimentology 61, 264-290.

Gély, J.-P., Lorenz, C., 1991. Analyse séquentielle de I'Eocène et de l'Oligocène du bassin Parisien (France). Oil \& Gas Science and Technology 46 (6), 713-747.
Gély, J.-P., Sztrákos, K., 2000. La tectonique pyrénéenne à l'Oligocène : une phase majeure de déformation en compression méconnue du Bassin aquitain (France). Compte Rendu de l'Académie des Sciences, Série IIA, Earth and Planetary Science, Paris, 332 (8), 507-512.

Giamboni, M., Ustaszewski, K., Schmid, S.M., Schumacher, M.E., Wetzel, A., 2004. Plio-Pleistocene transpressional reactivation of Paleozoic and Paleogene structures in the Rhine-Bresse transform zone (northern Switzerland and eastern France). Internation Journal of Earth Sciences, Geologische Rundschau 93, 207-223.

Gierlowski-Kordesch E.H., Rust, B.R., 1994. The Jurassic East Berlin Formation, Hartford Basin, Newark Supergroup (Connecticut and Massachusetts): a saline lake-playa- alluvial plain system. In: Renaut, R.W., Last, W.M. (Eds.), Sedimentology and Geochemistry of Modern and Ancient Saline Lakes. SEPM Special Publication 50, pp. 249-265

Gigot, P., Gubler, Y., Kandel, C., Triat, J.M., Truc, G., 1975. Alpes de Provence et Vaucluse : régions de Forcalquier-Manosque, Apt, Murs, Mormoiron-Pernes. $9^{\text {th }}$ International Sedimentological Congress, Nice, 1-162

Gorini, C., Viallard, P., Déramond, J., 1991. Modèle d'inversion structurale négative : la tectonique extensive post-nappe du fossé de Narbonne-Sigean (Corbières, Sud de la France). Comptes rendus de I'académie des Sciences de Paris 312, 1013-1019.

Gorini, C., 1993. Géodynamique d'une marge passive : le golfe du Lion (Méditerranéen Occidentale). (Ph.D. Thesis). Université Paul Sabatier, Toulouse III, France (256 pp.).

Gorini, C., Mauffret, A., Guennoc, P., Le Marrec, A., 1994. Structure of the Gulf of Lions (Northwestern Mediterranean Sea): A review. In: Mascle, A. (Ed.), Hydrocarbon and Petroleum Geology of France. Springer-Verlag, Berlin, pp. 223-243.

Gruas-Cavagnetto, C., 1973. Première contribution à l'étude de la palynoflore de la formation de Célas (Bassin d'Alès, Gard). Paléobiologie Continentale 4, 1-14.

Gudefin, H., 1977. Recherches sur la géologie profonde fosse de Valence (Drôme). Bureau de Recherches Géologiques et Minières (BRGM), Orléans (58pp.).

Guennoc, P., Gorini, C., Mauffret, A., 2000. Geological history of the Gulf of Lions: mapping the OligoceneAquitanian rift and Messinian surface. Géologie de la France 3, 67-97.

Guilhaumou, N., Touray, J.C., Perthuisot, V., Roure, F., 1996. Palaeocirculation in the basin of southeastern France sub-alpine range: a synthesis from fluid inclusions studies. Marine and petroleum geology 13 (6), 695-706. Guo, L., Riding, R., 1998. Hot-spring travertine facies and sequences, Late Pleistocene Rapolano Term, Italy. Sedimentology 45, 163-180.

Hargrave, J.E., Hicks, M.K., Scholz, C.A., 2014. Lacustrine carbonates from Lake Turkana, Kenya: a depositional model of carbonates in an extensional basin. Journal of Sedimentary Research 84, 224-237.

Hartenberger, J.-L., Sigé, B., Sudre, J., Vianey-liaud, M., 1970. Nouveaux gisements de Vertébrés dans le bassin tertiaire d'Alès (Gard). Bulletin de la Société Géologique de France 7 (12), 879-885.

Herczeg, A.L., Dogramaci, S.S., Leaney, F.W.J., 2001. Origin of dissolved salts in a large, semi-arid groundwater system: Murray Basin, Australia. Marine Freshwater Research 52,41-52.

Hinsken, S., Ustaszewski, K., Wetzel, A., 2007. Graben width controlling syn-rift sediementation: the Palaeogene southern Upper Rhine Graben as an exemple. International Journal of Earth Sciences, Geologische Rundschau 96, 979-1002. 
Holland, H.D., Borcsik, M., Munoz, J., Oxburgh, U.M., 1963. The coprecipitation of $\mathrm{Sr}+2$ with aragonite and of $\mathrm{Ca}+2$ with strontianite between 90 and $100^{\circ} \mathrm{C}$. Geochimica et Cosmochimica Acta 27, 957-977.

Hren, M.T., Sheldon, N.D., Grimes, S.T., Collinson, M.E., Hooker, J.J., Bugler, M., Lohmann, K.C., 2013. Terrestrial cooling in Northern Europe during the Eocene-Oligocene transition. Proceedings of the National Academy of Sciences of the United States of America, P.N.A.S. 110 (19), 7562-7567.

Huerta, P., Armenteros, I., Recio, C., Blanco, J.A., 2010. Palaeogroundwater evolution in playa-lake environments - Sediemtnary facies and stable isotope record (Palaeogene, Almazan basin, Spain). Palaeogeography, Palaeoclimatology, Palaeoecology 286, 135-148.

Ivany, L.C., Patterson, W.P., Lohmann, K.C., 2000. Cooler winters as a possible cause of mass extinctions at the Eocene/Oligocene boundary. Nature 407, 887-890.

James, V., Canerot, J., 1999. Diapirisme et structuration post-triasique des Pyrénées occidentales et de l'Aquitaine méridionale (France). Eclogae Geologicae Helvetiae 92, 63-72.

Katz, M.E., Miller, K.G., Wright, J.D., Wade, B.S., Browning, J.V., Cramer, B.S., Rosenthal, Y., 2008. Stepwise transition from the Eocene greenhouse to the Oligocene icehouse. Nature Geoscience 1, 329-334.

Kayseri-Özer, M.S., 2013. Spatial distribution of climatic conditions from the Middle Eocene to Late Miocene based on palynoflora in Central, Eastern and Western Anatolia. Geodynamica Acta 26, 122-157.

Kayseri-Özer, M.S., Akgün, F., Mayda, S., Kaya, T., 2014. Playnofloras and vertebrates from Muğla-Ören region (SW Turkey) and palaeoclimate of the Middle Burdigalian-Langhian period in Turkey. Bulletin of Geosciences $89(1), 137-162$.

Kinsman, D.J.J., Holland, H.D., 1969. The coprecipitation of cations with $\mathrm{CaCO} 3-\mathrm{IV}$. The coprecipitation of $\mathrm{Sr} 2+$ with aragonite between $16^{\circ}$ and $96^{\circ} \mathrm{C}$. Geochimica et Cosmochimica Acta 33, 1-17.

Kowalke, T., 2006. Ecological implications of molluscan ontogenetic strategies - examples from aquatic ecosystems of the Cenozoic Iberian Peninsula. Lethaia 39, 195-209.

Land, L.S., Hoops, G.K., 1973. Sodium in carbonate sediments and rocks; a possible index to the salinity of diagenetic solutions. Journal of Sedimentary Research 43 (3), 614-617.

Lanès, S., Palma, R.M., $1998 . \quad$ Environmental implications of oncoids and associated sediments from the Remoredo Formation (Lower Jurassic) Mendoza, Argentina. Palaeogeography, Palaeoclimatology, Palaeoecology 140, 357-366

Lespinasse, P., Aloisi, J.-C., Barruol, J., Durand-Delga, M., Got, H., Monaco, A., Marchal, J.-P., 1982. Notice explicative. Carte géologique de France (1/50 000), Narbonne (1061). Bureau de Recherches Géologiques et Minières (BRGM), Orléans (51 pp.).

Lesueur, J.-L., 1991. Etude sédimentologique et stratigraphique du Bassin Paléogène d'Apt-ManosqueForcalquier (Alpes de Haute Provence). Modalités de la transition Burdigalienne. (Ph.D. Thesis). University M. de Montaigne, Bordeaux III, France (407 pp.).

Lettéron, A., Fournier, F., Hamon, Y, Villier, L., Margerel, J.-P., Bouche, A., Feist, M., Joseph, P., 2017. Multi-proxy paleoenvironmental reconstruction of saline lake carbonates: Paleoclimatic and paleogeographic implications (Priabonian-Rupelian, Issirac Basin, SE France). Sedimentary Geology 358, 97120.
Lévy, A., 1972. Données préliminaires sur la formation de gypse dans les milieux margin-littoraux du golfe du Lion, Compte Rendus de l'Académie des sciences de Paris 275, 2579-2582

Liu, Z.H., Pagani, M., Zinniker, D., DeConto, R., Huber, M., Brinkhuis, H., Shah, S.R., Leckie, R.M., Pearson, A., 2009. Global cooling during the EoceneOligocene climate transition. Science 323, 1187-1190.

Lokier, S.W., Al Junaibi, M., 2016. The petrographic description of carbonate facies: are we all speaking the same language? Sedimentology 63, 1843-1885.

Macpherson, J.H., Gabriel, C.J., 1962. Marine Mollusks of Victoria. National Museum of Victoria, Melbourne Univ. Press, Melbourne (575 pp.).

Mascle A., Vially, R., 1999. The petroleum systems of the Southeast Basin and Gulf of Lion (France). In: Durand, B., Jolivet, L., Horváth, F., Séranne, M. (Eds.) The Mediterranean Basins: Tertiary Extension within the Alpine Orogen. Geological Society, London, Special Publications 156, pp. 121-140.

Mauffret, A., Gorini, C., 1996. Structural style and geodynamic evolution of Camargue and Western Provencal basin, southeastern France. Tectonics 15 (2), 356-375.

Mees, F., Casteñeda, C., Herrero, J., Van Ranst, E., 2012. The nature and significance of variations in gypsum crysta morphology in dry lake basins. Journal of Sedimentary Research 82, 37-52.

Merle, O., Michon, L., 2001. The formation of the West European rift: A new model as exemplified by the Massif Central area. Bulletin de la Société géologique de France $172(2), 213-221$.

Meulenkamp, J.E., Sissingh W., 2003. Tertiary palaeogeography and tectonostratigraphic evolution of the Northern and Southern Peri-Tethys platforms and the intermediate domains of the African-Eurasian convergent plate boundary zone. Palaeogeography, Palaeoclimatology, Palaeoecology 196, 209-228.

Michon, L., 2000. Dynamique de l'extension continentale - Application au Rift Ouest-Européen par l'étude de la province du Massif Central. (Ph.D. Thesis). Université Blaise Pascal, France (266 pp.).

Miller, K.G., Wright, J.D., Katz, M.E., Wade, B.S. Browning, J.V., Cramer, B.S., Rosenthal, Y., 2009. Climate threshold at the Eocene-Oligocene transition: Antarctic ice sheet influence on ocean circulation. In: Koeberl, C., Montanari, A. (Eds.) The Late Eocene EarthHothouse, Icehouse, and Impacts. The Geological Society of America, Special Paper 452, pp. 1-10.

Moore, D.M., Reynolds, R.C., 1997. X-Ray Diffraction and the Identification and Analysis of 679 Clay Minerals. Oxford University Press, New York (400 pp.).

Morton, B., 1983. Mangrove Bivalves. In: Russell-Hunter, W.D. (Ed.) The Mollusca. Orlando \& others, Academic Press 6, pp. 77-138

Mosbrugger, V., Utescher, T., Dilcher, D.L., 2005. Cenozoic continental climatic evolution of Central Europe. Proceedings of the National Academy of Sciences of the United States of America (PNAS) 102 (42), 14964-14969.

Ollivier-Pierre, M.-F., 1980. Etude palynologique (spores et pollens) de gisements paléogènes du Massif Armoricain. Stratigraphie et paléogéographie. (Ph.D. Thesis). Université de Rennes, France, Mémoires de la société géologiques et minéralogique de Bretagne 25 (239 pp.).

Ozsvárt, P., Kocsis, L., Nyerges, A., Győri, O., Pálfy, J., 2016. The Eocene-Oligocene climate transition in the Central Paratethys. Palaeogeography, Palaeoclimatology, Palaeoecology 459, 471-487. 
Pentecost, A., Viles, H., 1994. A review and reassessment of travertine classification. Géographie physique et Quaternaire 48 (3), 305-314.

Petschick, R., 2000. MacDIff Ver. 4.2.3. Manual Geologisch-Palaontologisches Institute Johann Wolfgang Goethe Universitat Frankfurt Main senckenberganlage 32-34.

Playà, E., Rosell, L., 2005. The Celestine problem in gypsum Sr geochemistry: an evaluation of the purifying methods of gypsiferous samples. Chemical Geology 221, 102-116.

Playà, E., Cendón, D.I., Travé, A., Chivas, A.R., García, A., 2007. Non-marine evaporites with both inherited marine and continental signatures: The Gulf of Carpentaria, Australia, at $\sim 70$ ka. Sedimentary Geology 201, 267-285.

Plaziat, J.-C., 1991. Paleogeographic significance of the Cardium, Potamids and Foraminifera living intracontinental salt lakes of North Africa (Sahara Quaternary, Egypt Present lakes). Journal of African Earth Sciences 12, 383-389

Plaziat, J.-C., 1993. Modern and fossil Potamids (Gastropoda) in saline lakes. Journal of Paleolimnology 8, 163-169.

Postigo-Mijarra, J.M., Barrón, E., Gómez Manzaneque, F, Morla, C., 2009. Floristic changes in the Iberian Peninsula and Balearic Islands (south-west Europe) during the Cenozoic. Journal of Biogeography 36, 2025-2043.

Reichenbacher, B., 2004. A partly endemic euryhaline fish fauna (otoliths, teeth) from the Early Miocene of the Aix-Basin (Provence, southern France). Cour. Forsch.-Inst. Senckenberg 246, 113-127.

Remy, J.A., 1985. Nouveaux gisements de mammifères et reptiles dans les grès de Célas (Eocène sup. du Gard). Etude des Palaeothériidés (Perissodactyla, Mammalia). Palaeontographica Abteilung A, 189, 171-225.

Remy, J.A., 1994. Une faunule de vertébrés sous la base des Grès de Célas (Eocène supérieur) à St-Dézery (Gard). Palaeovertebrata 23 (1-4), 211-216.

Remy, J.A., 1999. Deux nouveaux gisements de vertébrés fossiles dans la formation de Célas (Eocène supérieur du Gard). Bulletin de la Société d'étude des Sciences Naturelles de Nîmes et du Gard 62, 16-22.

Remy, J.A., Lesage, J.-L., 2005. Un nouveau gisement de vertébrés d'âge Priabonien et son contexte géologique (Tranchée de Nozières, Gard). Bulletin de la Société d'étude des Sciences Naturelles de Nîmes et du Gard 65, 7-14

Renard, M., 1975. Geochemical study of a carbonaterich facies in the Northern Border-area of the Ludian gypsum in the Paris Basin. Sedimentary Geology 13, 191-231.

Riveline, J., Berger, J.-P., Feist, M., Martin-closas, C., Schudack, M., Soulié-Märsche, I., 1996. European Mesozoic-Cenozoic charophyte biozonation. Bulletin de la Société géologique de France 167 (3), 453-468.

Rögl, F., 1999. Mediterranean and Parathethys. Facts and hypotheses of an Oligocene to Miocene paleogeography (short overview). Geologica Carpathica 50 (4), 339-349.

Roman, F., 1910. Faune saumâtre du sannoisien du Gard. Bulletin de la Société géologique de France, 4, 927-955.

Rouchy, J.-M., 1997. Paleogene Continental Rift System of Western Europe: Locations of Basins, Paleogeographic and Structural Framework, and the Distribution of Evaporites. In: Busson, G., Schreiber, B.C. (Eds.), Sedimentary Deposition in Rift and Foreland Basins in France and Spain. Columbia Univ. Press, New York, pp. 45-94.
Rouchy, J.-M., Blanc-Valleron, M.-M., 2009. Les évaporites matériaux singuliers, milieux extrêmes. Vuibert, Paris (184 pp.).

Rougier, G., Ford, M., Christophoul F., Bader A.-G., 2016. Stratigraphic and tectonic studies in the central Aquitaine Basin, northern Pyrenees: Constraints on the subsidence and deformation history of a retro-foreland basin. Comptes Rendus Géosciences 348, 224-235.

Roussé, S., 2006. Architecture et dynamique des séries marines et continentales de l'Oligocène Moyen et Supérieur du Sud du Fossé Rhénan: Evolution des milieux de dépôt en contexte de rift en marge de l'avantpays alpin. (Ph.D. Thesis). Université de Strasbourg, France (474 pp.).

Samanta, A., Bera, M.K., Sarkar, A., 2016. Climatemodulated sequence development in a tropical rift basin during the Late Palaeocene to Early Eocene super greenhouse Earth. Sedimentology 63, 917-939.

Sanchis, E., Séranne, M., 2000. Structural style and tectonic evolution of a polyphase extensional basin of the Gulf of Lion passive margin: Tertiary Alès basin, South France. Tectonophysics 322, 219-242.

Sanchis, E., 2000. Méthodologie d'Imagerie 3D des bassins, des exemples dans le Bassin du Sud-Est. Unpublished Report, Technical report from Université de Montpellier, France and Bureau de Recherches Géologiques et Minières, Orléans (BRGM), (70 pp.).

Sanjuan, J., Martin-Closas, C., Costa, E., Barbera, X., Garcés, M., 2014. Calibration of Eocene-Oligocene charophyte biozones in the Eastern Ebro Basin (Catalonia, Spain). Stratigraphy 11 (1), 61-81

Schackleton, N.J., 1986. Paleogene stable isotope events. Palaeogeography, Palaeoclimatology, Palaeoecology 57, 91-102.

Schuler, M., 1990. Environnements et paléoclimats paléogènes. Palynologie et biostratigraphie de l'Eocène et de l'Oligocène inférieur dans les fossés rhénan, rhodanien et de Hesse. Document du Bureau de Recherches Géologiques et Minières (BRGM) 190, Orléans (503 pp.).

Séranne, M., Benedicto, A., Labaum, P., Truffet, C., Pascal, G., 1995. Structural style and evolution of the Gulf of Lion Oligo-Miocene rifting: role of the Pyrenenan orogeny. Marine and Petroleum Geology 12 (8), 809-820.

Séranne, M., 1999. The Gulf of Lion continental margin (NW Mediterranean) revisited by IBS: an overview. In: Durand B., Jolivet, L., Horváth, F., Séranne, M. (Eds.), The Mediterranean Basins: Tertiary Extension within the Alpine Orogen. Geological Society, London, Special Publications 156, pp. 15-36.

Sheldon, N.D., Mitchell, R.L., Collinson, M.E., Hooker, J.J., 2009. Eocene-Oligocene transition paleoclimatic and paleoenvironmental record from the Isle of Wight (UK). The Geological Society of America, Special Paper 452, 249-259

Singer, A, 1984. Pedogenic palygorskite in the arid environment. In: Singer, A., Galán, E. (Eds.), Palygorskite-Sepiolite-Occurrences, Genesis and Uses. (Developments in Sedimentology 37, Elsevier, Amsterdam, pp. 169-176.

Sissingh, W., 2001. Tectonostratigraphy of the West Alpine Foreland: correlation of Tertiary sedimentary sequences, changes in eustatic sea-level and stress regimes. Tectonophysics 333, 361-400.

Sissingh, W., 2003. Tertiary paleogeographic and tectonostratigraphic evolution of the Rhenish Triple Junction. Palaeogeography, Palaeoclimatology, Palaeoecology 196, 229-263.

Sissingh, W., 2006. Syn-kinematic palaeogeographic evolution of the West European Platform: correlation with 
Alpine plate collision and foreland deformation. Géologie en Mijnbouw, Netherlands Journal of Geosciences 85 (2), 131-180.

Sittler, C., Schuler, M., Caratini, C., Châteauneuf, J.J., Gruas-Cavagnetto, C., Jardine, S., Ollivier, M.F., Roche, E., Tissot, C., 1975. Extension stratigraphique géographique et écologie de deux genres polliniques paléogènes observés en Europe occidentale: Aglaoreidia et Boehlensipollis. Bulletin de la Société Botanique de France 122, 231-245.

Soták, J., 2010. Paleoenvironmental changes across the Eocene-Oligocene boundary: insights from the CentralCarpathian Paleogene Basin. Geologica Carpathica 61 (5), 393-418.

Spencer, R.J., Eugster, H.P., Jones, B.F., 1985. Geochelmistry of great Salt Lake, Utah II: PleistoceneHolocene evolution. Geochimica et Cosmochimica Acta 49 (3), 739-749.

Talbot, M.R., 1990. A review of the palaeohydrological interpretation of carbon and oxygen isotopic ratios in primary lacustrine carbonates. Chemical Geology, Isotope Geoscience Section 80, 261-279.

Talbot, M.R., Allen, P.A., 1996. Lakes. In: Reading, H.G. (Ed.), Sedimentary Environments: Processes, Facies and Stratigraphy. Blackwell Science, Oxford, pp. 83-124.

Talbot, M.R., Kelts, K., 1990. Paleolimnological signatures from carbon and oxygen isotopic ratios in carbonates from organic carbon-rich lacustrine sediments. In: Katz, B.J. (Ed.) Lacustrine Basin Exploration: Case Studies and Modern Analogs. American Association of Petroleum Geologists (AAPG), Tulsa, pp. 99-112.

Taylor, M.P., Drysdale, R.N., Carthew, K.D., 2004. The formation and environmental significance of calcite rafts in tropical tufa-depositing rivers of northern Australia. Sedimentology 51, 1089-1101.

Tidwell, W.D., Parker, L.R., 1987. Aurealcaulis crossii gen. et sp. Nov., an arborescent osmundaceous trunk from the Fort Union Formation (Paleocene), Wyoming. American Journal of Botany 74, 803-812.

Tramoy, R., Salpin, M., Schnyder, J., Person, A., Sebilo, M., Yans, J., Vaury, V., Fozzani, J., Bauer, H., 2016. Stepwise palaeoclimate change across the Eocene-Oligocene transition in continental NW Europe by mineralogical assemblages and $\mathrm{d} 15 \mathrm{~N}$ org (Rennes Basin, France). Terra Nova 28, 212-220.

Triat, J.M., Truc, G., 1974. Evaporites paléogènes du domaine rhodanien. Revue de géographie physique et de géologie dynamique 16, 235-262.

Truc, G., 1978. Lacustrine sedimentation in an evaporitic environment: the Ludian (Paaeogene) of the Mormoiron basin, southeastern France. Special Publications of the International Association of Sedimentologists 2, 189-203.

Uhl, D., Klotz, S., Traiser, C., Thiel, C., Utescher, T., Kowalski, E., Dilcher, D.L., 2007. Cenozoic paleotemperatures and leaf physiognomy - A European perspective. Palaeogeography, Palaeoclimatology, Palaeoecology 248, 24-31.

Van Konijnenburg-Ban Cittert, J.H.A., 2002. Ecology of some Late Triassic to Early Cretaceous ferns in Eurasia. Review of Palaeobotany and Palynology 119, 113-124.

Vandenberghe, N., Hilgen, F.J., Speijer, R.P., 2012. The Paleogene Period. In: Gradstein, F.M., Ogg, J.G., Schmitz, M., Ogg, G. (Eds.), The Geologic Time Scale 2012. Elsevier, Amsterdam, pp. 855-921.

Vengosh, A., Chivas, A.R., Starinsky, A., Kolodny, Y., Baozhen, Z., Pengxi, Z., 1995. Chemical and boron isotope compositions of non-marine brines from the Qaidam Basin, Qinghai, China. Chemical Geology 120, 135-154.

Verrecchia, E.P., Le Coustumer M.-N., 1996. Occurrence and genesis of palygorskite and associated clay minerals in a Pleistocene calcrete complex, Sde Boquer, Negev desert, Israel. Clay Minerals 31, 183-202. Viallard, P., Gorini, C., 1994. Modalités de la fracturation d'une marge passive préstructurée : le golfe du Lion (Méditerranée nord-occidentale). Comptes Rendus de l'Académie des Sciences de Paris 319 (2), 567-572.

Visscher, P.T., Reid, R. P., Bebour, B.M., 2000. Microscale observations of sulfate reduction: Correlation of microbial activity with lithified micritic laminae in modern marine stromatolites. Geology 28 (10), 919-922. Wattine, A., Vennin, E., De Wever, P., 2003. Evolution d'un environnement carbonaté lacustre à stromatolithes, par l'approche paléo-écologique (carrière de Montaigule-Blin, bassin des Limagnes, Allier, France). Bulletin de la Société géologique de France 174, 243-260.

Ziegler, P.A., 1988. Evolution of the Arctic-North Atlantic and the Western Tethys. American Association of Petroleum Geologists, AAPG Memoir 43, Tulsa (189 pp.). Ziegler, P.A., 1992. European Cenozoic rift system. In: Ziegler, P.A. (Ed.), Geodynamics of Rifting, Volume I, Case History Studies on Rifts: Europe and Asia. Tectonophysics 208, pp. 91-111.

Ziegler, P.A., Dèzes, P., 2005. Neogene uplift of Variscan Massifs in the Alpine foreland: Timing and controlling mechanisms. Global and planetary change $58,1-4,237-269$. 